\title{
The self-perceived leadership styles of chief state school officers and models of educational governance
}

\author{
Lori A. Wiggins \\ West Virginia University
}

Follow this and additional works at: https://researchrepository.wvu.edu/etd

\section{Recommended Citation}

Wiggins, Lori A., "The self-perceived leadership styles of chief state school officers and models of educational governance" (2013). Graduate Theses, Dissertations, and Problem Reports. 3644.

https://researchrepository.wvu.edu/etd/3644

This Dissertation is protected by copyright and/or related rights. It has been brought to you by the The Research Repository @ WVU with permission from the rights-holder(s). You are free to use this Dissertation in any way that is permitted by the copyright and related rights legislation that applies to your use. For other uses you must obtain permission from the rights-holder(s) directly, unless additional rights are indicated by a Creative Commons license in the record and/ or on the work itself. This Dissertation has been accepted for inclusion in WVU Graduate Theses, Dissertations, and Problem Reports collection by an authorized administrator of The Research Repository @ WVU.

For more information, please contact researchrepository@mail.wvu.edu. 


\title{
THE SELF-PERCEIVED LEADERSHIP STYLES OF CHIEF STATE SCHOOL OFFICERS
} AND MODELS OF EDUCATIONAL GOVERNANCE

\author{
Lori A. Wiggins
}

\author{
Dissertation submitted to the \\ College of Education and Human Services \\ at West Virginia University \\ in partial fulfillment of the requirements \\ for the degree of
}

Doctor of Education

in

Educational Leadership Studies
Paul Chapman, Ph.D., Chair
Micah Fierstein, Ed.D.
Jerry Jones, Ph.D.
Anne Nardi, Ph.D.
Bonnie Ritz, Ed.D.
Department of Curriculum and Instruction \& Literacy Studies
Morgantown, West Virginia
2013

Keywords: Chief State School Officers; State Education Governance; Leadership Styles. Copyright 2013 Lori A. Wiggins 


\title{
ABSTRACT \\ The Self-perceived Leadership Styles of Chief State School Officers and Models of Educational Governance
}

\author{
Lori A. Wiggins
}

This study examined the leadership styles of the chief state school officers of the United States and the District of Columbia. The entire population of 51 chief state school officers was surveyed and a response rate of $60 \%$ was obtained. The study examined the relationship between the leadership style, select demographic variables, and the specific models of educational governance. The Leadership Orientation (Self) Instrument (Bolman \& Deal, 1990) was used. The survey instrument is based on the Bolman and Deal (1984, 1991c, 2003) fourframe model, which includes the structural, human resource, political, and symbolic leadership frames. The predominant leadership style of the chief state school officer was a multi-frame leadership style (53.3\%), followed by a paired-frame leadership style $(23.3 \%)$ with the least used leadership style being a single-frame (10.0\%). The number of chief state school officers using a multi-frame leadership style was statistically significant. Additionally, a statistically significant relationship was found between the use of the human resource frame and the highest degree earned. Finally, the study concluded that a significant relationship existed between the years of experience as a chief state school officer leadership in comparison to the leadership frame means and a multi-frame leadership style. It appeared that the longer an individual was a chief state school officer the more likely they were to utilize all four frames and to possess a multi-frame leadership style. 


\section{DEDICATION}

I dedicate this work to those educators in West Virginia who continue to fight the good fight for educator quality and for rich educational opportunities for children. May you not grow weary; press on. 


\section{ACKNOWLEDGEMENTS}

The journey of a thousand miles begins with a single step and includes a thousand encounters. I am grateful for the encounters and for those I have encountered. If we are the sum of our experiences, then my total is exponentially more positive as a result of the dissertation expedition.

I wish to thank Dr. Anne Nardi, my chairperson, for her steadfast guidance, encouragement, and optimism. I also wish to thank Dr. DJ Hendricks for her statistical help, delivered with wit and wisdom.

I also wish to thank the members on my committee for sharing their professional expertise: Dr. Paul Chapman, Dr. Micah Fierstein, and Dr. Jerry Jones. I am also very grateful for the support of Dr. Steven L. Paine and the letter of introduction to his fellow chief state school officers, encouraging them to participate in the research project.

I deeply indebted to the coterie of friends and mentors, who pushed, pulled, cajoled, threatened, supported, and cared for me during this journey: Linda Boyd, Lee Ebersole, Robert Hagerman, Karen Huffman, R. Matthew Kittle, Gus Penix, Marlene Price, Bonnie Ritz, and Marla Wilcox-Eddy. I am also grateful to Ron Scott, Jr. for his steadfast belief that I was built for this.

I also want to thank my Papa, Walter Wiggins, for his enduring belief that his daughter can do anything she sets her mind to and my brother, Xavier Wiggins for his quiet, yet constant support. 
I am especially thankful for my best friend Letha Zook. I would not have been able to complete this adventure without her love, support, and wisdom. 


\section{TABLE OF CONTENTS}

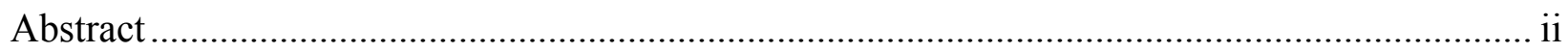

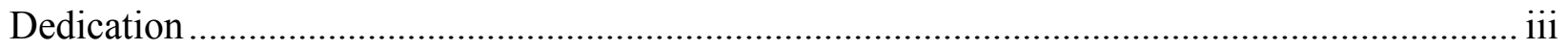

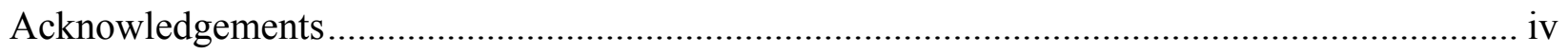

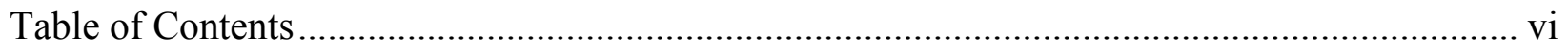

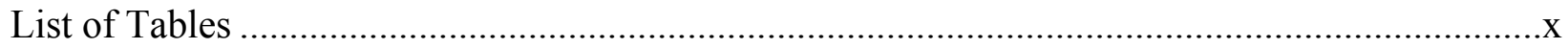

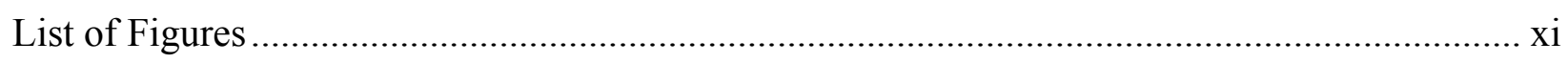

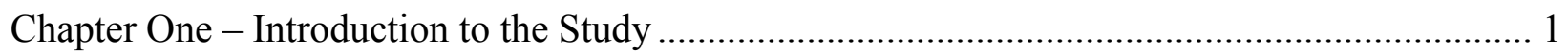

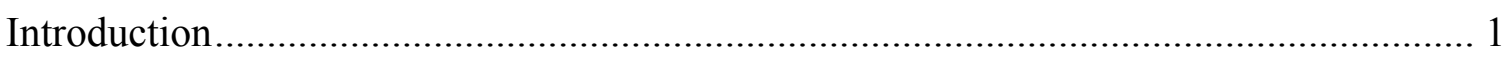

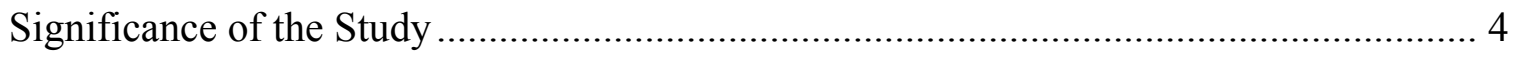

Statement of the Problem ……………………………........................................... 5

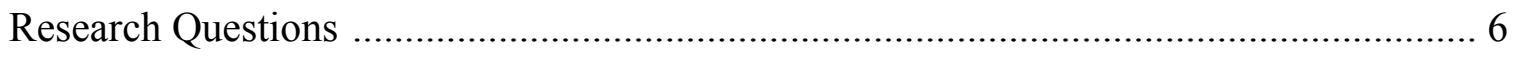

Statement of the Problem …………………………................................................... 6

Overview of Research Methods …………………….............................................. 7

Delimitations of the Study ......................................................................................... 7

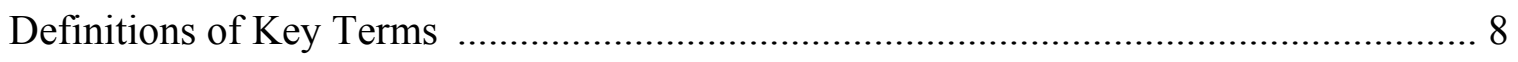

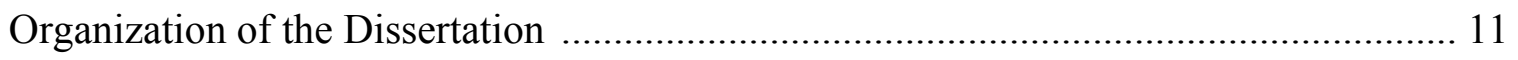

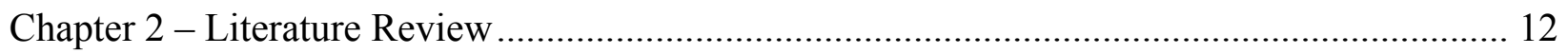

A Historical Perspective of Chief State School Officer................................................... 12

The Transitioning Role of Chief State School Officers.................................................. 15

The Current Role of Chief State School Officers .......................................................... 17

Historical Perspective of State Models of Educational Governance ................................ 24 
LEADERSHIP STYLES OF CHIEF STATE SCHOOL OFFICERS vii

Current Models of State Educational Governance.................................................... 26

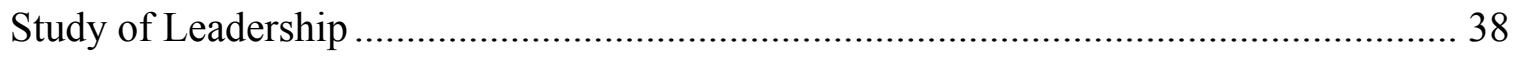

The Trait Approach .............................................................................. 39

The Power and Influence Approach ......................................................... 41

The Behavior Approach ................................................................................ 43

Situational Theories of Leadership ......................................................... 46

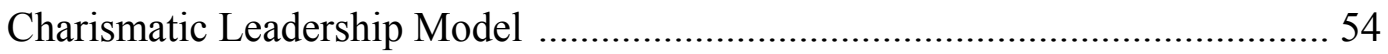

Transformational Leadership Model.......................................................... 56

Multiple-Linkage Model ..................................................................... 57

Bolman and Deal's Four-Frame Leadership Orientation Model ................................... 58

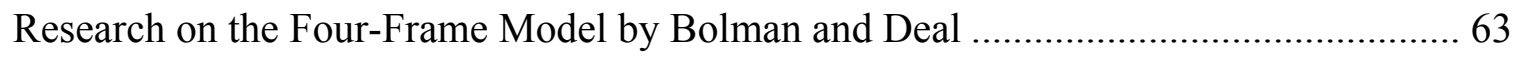

Research Using Bolman and Deal's Four-Frame Model ........................................... 65

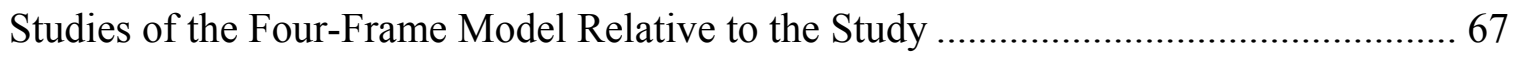

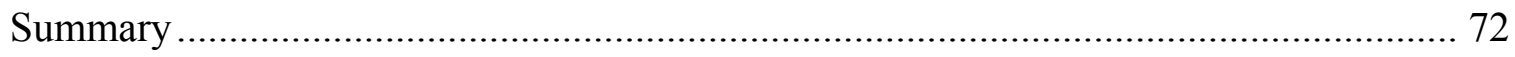

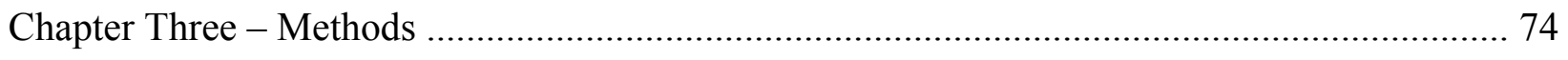

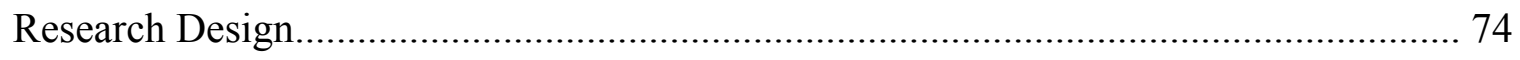

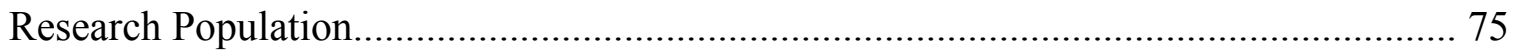

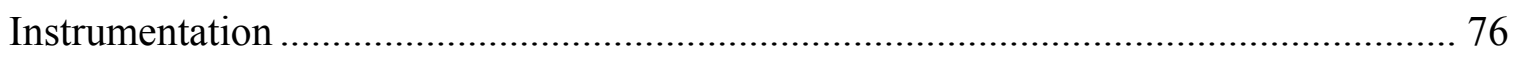

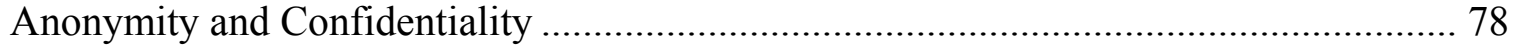

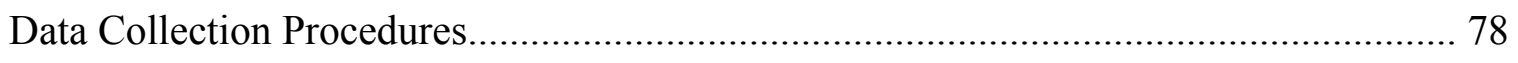

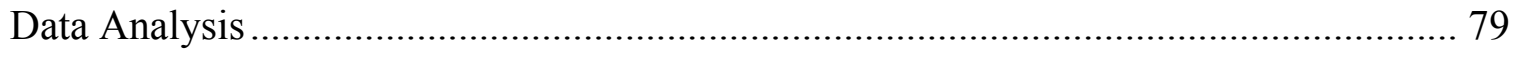

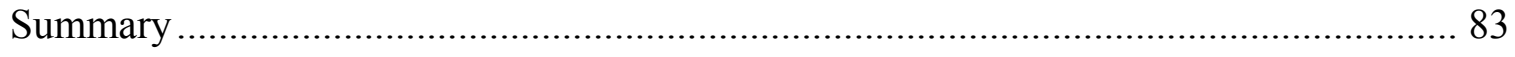


LEADERSHIP STYLES OF CHIEF STATE SCHOOL OFFICERS viii

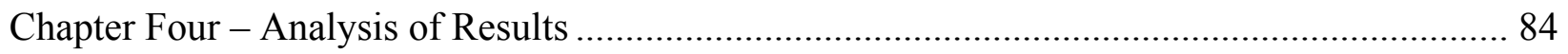

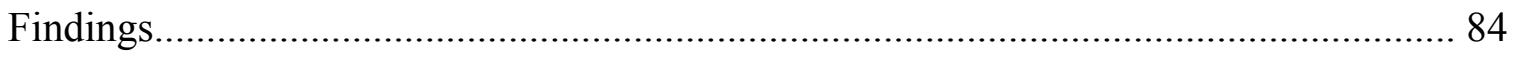

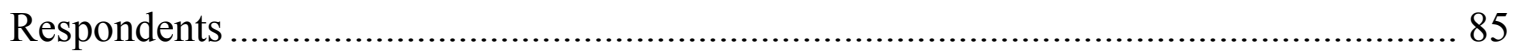

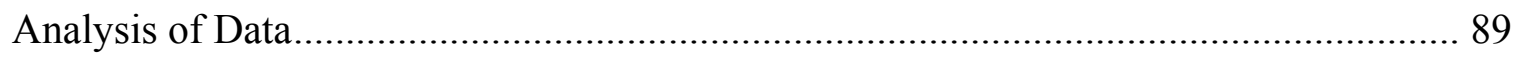

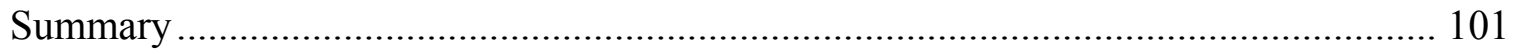

Chapter Five - Conclusions and Recommendations ...................................................... 104

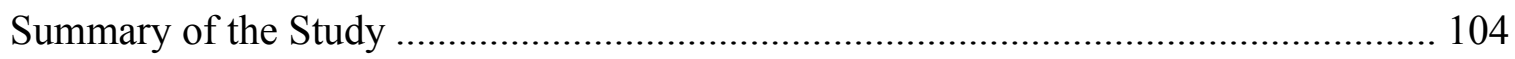

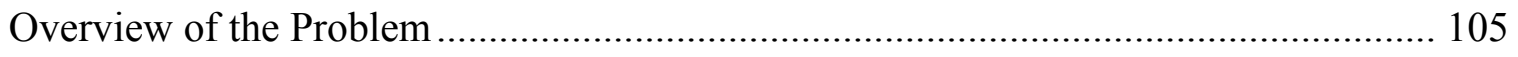

Description of the Chief State School Officers........................................................ 106

Findings Related to the Literature ................................................................. 106

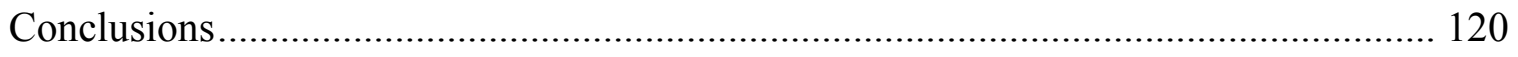

Recommendations for Practice ........................................................ 120

Recommendations for Further Study .................................................... 121

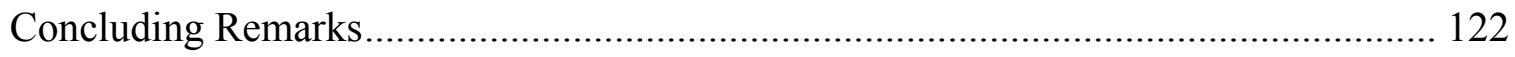

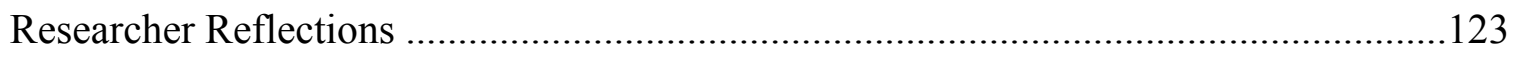

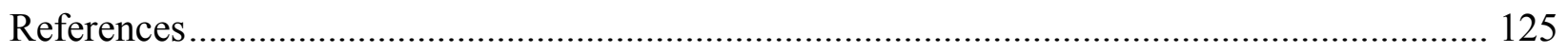

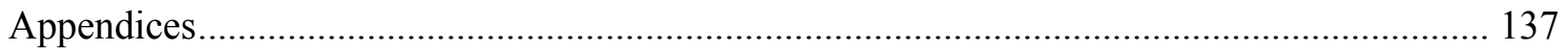

A. Permission to Use Survey Instrument and Distribute Electronically...................... 137

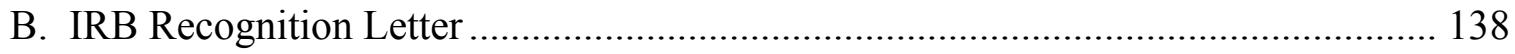

C. Participant Letter to Chief State School Officers................................................. 140

D. Note card from Dr. Steven L. Paine .............................................................. 142

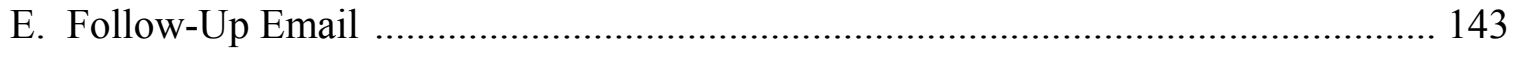


LEADERSHIP STYLES OF CHIEF STATE SCHOOL OFFICERS ix

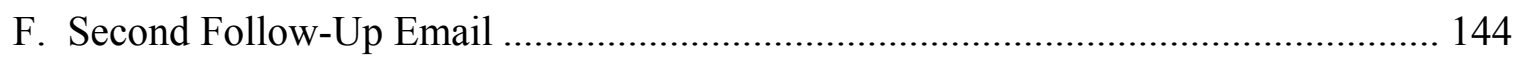

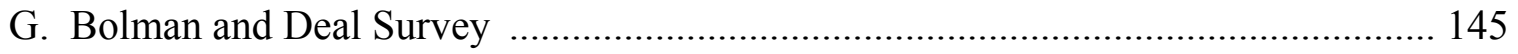

H. Chief State School Officer Questionnaire....................................................... 146 


\section{TABLES}

Table 1. Salaries of chief state school officers and highest paid city school superintendents in

$$
1950
$$

Table 2. Minimum Qualifications for Chief State School Officers 19

Table 3. Traits and Skills Associated with Effective Leadership ....................................... 41

Table 4. Response Rate by Model of Educational Governance .......................................... 87

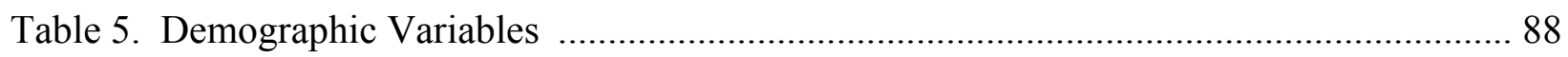

Table 6. Years of Experience of Chief State School Officers ............................................... 89

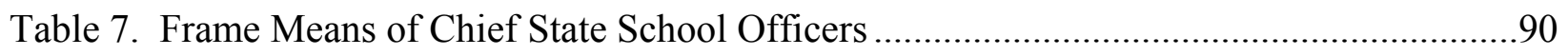

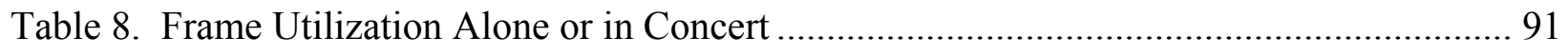

Table 9. Leadership Style and Frame Pattern .............................................................. 92

Table 10. One-Way Analysis of Variance of Human Resource Frame Mean and Highest Degree

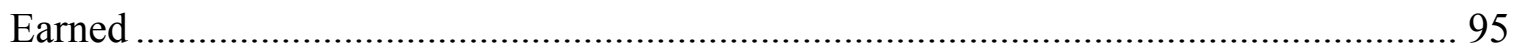

Table 11. Correlation of Years of Experience as CSSO and Frame Mean.............................. 96

Table 12. Leadership Style and Frame Pattern by Age .................................................... 97

Table 13. Leadership Style and Frame Pattern by Gender ................................................ 98

Table 14. Leadership Style and Frame Pattern by Highest Degree Earned............................ 100

Table 15. Frame Means by Model of Educational Governance ........................................ 101

Table 16. Leadership Style and Frame Pattern by Model of Educational Governance........... 102 


\section{FIGURES}

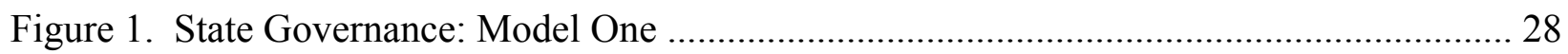

Figure 2. State Governance: Model Two …………….......................................................... 30

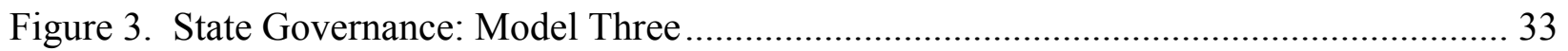

Figure 4. State Governance: Model Four................................................................................ 35 


\section{Chapter One}

This chapter provides an introduction to the study, the statement of the problem, the research questions, the significance of the problem, an overview of the research methods used, delimitations of the study, definitions of key terms, and the organization of the dissertation.

\section{Introduction}

The Tenth Amendment to the U. S. Constitution reserves to the states all powers not specifically delegated to the national government. Public education in the United States is not referenced in the U.S. Constitution and therefore is fundamentally a state responsibility.

Each state, by the vehicle of the state constitution or state statute, delineates the rights, responsibilities, and roles of those entrusted to ensure that the children of that state are provided a thorough, efficient and free education. The chief state school officers are the individuals who lead the state education agency and who are primarily responsible to ensure the efficient and equitable delivery of public education within each respective state.

In addition to each state having established the purview of the chief state school officers, each state has an established model of educational governance. The governance structures of 40 states fix discretely into four primary models. In Model One, the governor appoints the members of the state board of education, who in turn appoint the chief state school officer. In Model Two, the state board of education is elected and the elected board appoints the chief state school officer. In Model Three, the governor has the authority to appoint the members of the state board of education, while the chief state school officer is elected. And in Model Four, the governor has the authority to appoint both the state board of education and the chief state school officer. The educational governance structures of the remaining states and the District of Columbia do not classify discretely into one of the four models but rather are hybrids of different 
models. For the purpose of this study, the hybrid states were grouped with the governance model with which they most aligned. In summary, in 14 states the chief state school officer is appointed by an appointed state board of education, in 10 states the chief state school officer is appointed by an elected state board of education, in 14 states the chief state school officer is elected, and in 12 states and the District of Columbia both the state board of education and the chief state school officer are appointed by the governor and the mayor, respectively (Fultan, 2008).

Irrespective of the established governance structure, chief state school officers have the primary responsibility of ensuring that the school age children of their state are provided with a thorough and efficient education. In the Twelfth Annual Report of the Secretary of the Board of Education (1842), Horace Mann stated, "Education, then, beyond all other devices of human origin, is the great equalizer of the conditions of men - the balance-wheel of the social machinery" (p. 59). Within the parameters of the primary responsibility for the quality of the students' educational experiences, are myriad other responsibilities.

One significant area of accountability is the fiscal responsibility affiliated with the state education system. According to data from Education Commission of the States, in the school year $2007-2008$ the average percentage of K-12 revenue from state sources was $48.3 \%$ of the education budget for all 50 states and the District of Columbia (Zinth \& Bush, 2010). The percentage range was from $27.5 \%$ to $86.5 \%$ (Zinth \& Bush, 2010).

The chief state school officers are also accountable to a significant workforce affiliated with public, K-12 education. According to the United States Census Bureau, in 2010 over 11.1 million people were employed in a public education capacity. 
Chief state school officers have the enormous responsibility of ensuring that school age children have access to a quality education. The quality of education directly correlates to the welfare of respective states and the welfare of the nation. Students who are intellectually aware of the world around them and capable of taking an active role in promoting democracy is one product of a quality education (Goodman, 1989). Each state then has as its imperative a duty to deliver results, an educated populace.

The federal government has delegated to each state the responsibility for the education of its citizens, by way of the U. S. Constitution and permits a variety of educational system structures. However, there are still federal guidelines to which states are accountable. One such accountability measure is the reauthorized Elementary and Secondary Education Act, No Child Left Behind Act (2001). Section 101 in the Title 1 - Improving the Academic Achievement of the Disadvantaged identifies the purpose of the title is to guarantee that all school age children receive a fair, equal, and significant opportunity to obtain a high-quality education and to demonstrate at a minimum, proficiency on challenging state academic achievement standards and state academic assessments.

The chief state school officers are answerable for a significant portion of the states' fiscal resources, are in a position to provide leadership and direction for a significant population of the states' human resource capital, and are expected to contribute to the future wellbeing of the state by the quality of the educational experience and achievement of the school age children. Scholarly studies about the leadership styles of chief state school officers are noticeably absent from the literature. Given the importance of the position and myriad substantial responsibilities affiliated with this position, research about chief state school officers and their utilization of leadership is an important contribution to the body of research on leadership. Analytical 
research about the models of educational governance and the relationship between the governance models and the leadership styles of the chief state school officers is also absent from the literature.

Effective leadership is needed to successfully execute the duties of the office of chief state school officer and a leadership style that understands and adapts to the complex nature of organizations is essential. Bolman and Deal (1984, 1991c, 2003) posit that a leader's ability to navigate complex and complicated organizations is inextricably connected to their ability to understand and use multiple perspectives and their ability to think about the same thing in more than one way. The four frames or perspectives they suggest that are important to a leader's view of the organization are structural, human resource, political, and symbolic and a leader who is able use all four frames, or a multi-frame leadership style, is a leader that truly is effective (Bolman \& Deal, 1984, 1991c, 2003).

\section{Significance of the Study}

According to Mitra (2011), “A population that is better educated has less unemployment, reduced dependence on public assistance programs, and greater tax revenue. Education also plays a key role in the reduction of crime, improved public health, and greater political and civic engagement" (p. 5).

Chief state school officers have a primary responsibility to ensure that students have access to quality educational opportunities. The position of chief state school officer is pivotal not only from a financial and a human resource perspective, but also in terms of social justice and social responsibility. The manner by which chief state school officers perform their duties is greatly influenced by the leadership styles they possess and employ. 
Leadership is essential for accomplishing the goals that ensure the public school students of each state receive a quality education. Unfortunately, there is little literature that addresses the leadership styles of chief state school officers. No literature was found that explored the relationship between the leadership style of the chief state school officers and the model of educational governance in which the chief state school officer was situated.

For a variety of populations, this study may be meaningful. The absence of research related to the leadership styles and practices of chief state school officers precludes an analysis of best practices and leadership styles for individuals seeking to become chief state school officers and for those responsible for the selection of chief state school officers. Additionally, school leadership preparation programs currently do not have access to data about a population of individuals with some of the greatest responsibility for public education for the purposes of study, analysis and preparation. As a result, the paucity of research on models of educational governance and the relationship between the models and leadership styles of the chief state schools officers diminish the opportunity for an informed analysis of educational governance models.

\section{Statement of the Problem}

The research problem presented in this study was to identify the leadership styles of the 51 chief state school officers and to evaluate if a relationship existed between the leadership styles of the chief state school officers and the models of educational governance. The major hypothesis examined whether there was a statistically significant relationship between the leadership style of the chief state school officers and models of educational governance. The leadership styles were classified on the foundation of Bolman and Deal's (1984, 1991c, 2003) cognitive frames (structural, human resource, political, and symbolic). 


\section{Research Questions}

1. What are the leadership frames (structural, human resource, political, and symbolic) of the chief state school officers (Bolman \& Deal, 1984, 1991c, 2003)?

2. What are the leadership styles (no-frame, single-frame, paired-frame, and multi-frame) of the chief state school officers (Bolman \& Deal, 1984, 1991c, 2003)?

3. Are there differences between the leadership frames (structural, human resource, political, and symbolic) of the chief state school officers and selected demographic variables?

4. Are there differences between the leadership styles (no-frame, single-frame, pairedframe, and multi-frame) of the chief state school officers and selected demographic variables?

5. Is there a relationship between the leadership frames (structural, human resource, political, and symbolic) of the chief state school officers and models of educational governance?

6. Is there a relationship between the leadership styles (no-frame, single-frame, pairedframe, and multi-frame) of chief state school officers and models of educational governance?

\section{Statement of the Problem}

The purpose of this study was to describe the leadership styles of the chief state school officers and determine whether a relationship existed between the leadership styles of the chief state school officers and the respective models of educational governance. 


\section{Overview of Research Methods}

The research perspective of this study was quantitative. It was descriptive, self-report, survey research, which required the collection of standardized, quantifiable information from all study participants (Gay, Mills, \& Airasian, 2006). The participants in the study were the 51 chief state school officers from the United States and the District of Columbia.

The self-report, Bolman and Deal Leadership Orientation (Self) Survey instrument was used (1990). The reliability of the Leadership Orientation Survey had been verified by previous research (Bolman \& Deal, 1991a, 1991b). However, the validity of self-ratings of leadership is generally low (Bolman, 2010). The primary purpose of the study was to ascertain the chief state school officers' individual perception of their leadership styles, thus the low validity of the Leadership Orientation (Self) Survey did not negatively affect the results of this study. The survey instrument survey contains 32 statements that reflect the leadership frame orientations.

\section{Delimitations of the Study}

1. The boundaries of the study were confined to only the 51 chief state school officers from the United States and the District of Columbia. The chief state school officers of the Bureau of Indian Education, Department of Defense Education Activity, and the U.S. Territories of American Samoa, Guam, Northern Marina Islands, Puerto Rico, and the Virgin Islands were not included in this study.

2. This study was limited strictly to quantitative data. Although qualitative site studies would have yielded valuable information, this research focused on quantitative information only. 
3. This study only investigated the leadership styles of the chief state school officer using one instrument. This methodology may have limited the picture of the chief state school officers' leadership styles.

4. This study examined leadership frame orientations at one point in time.

\section{Definition of Key Terms}

Four leadership frames. The organizational schemata by which leaders may view any given situation, organize information, and make decisions; the four leadership frames are structural, human resource, political, and symbolic (Bolman \& Deal, 1984, 1991c, 2003).

The structural frame. Leaders who follow the structural frame emphasize goals, specialized roles, and formal relationships. They create rules, policies, procedures, and hierarchies to coordinate diverse activities into a unified strategy. They are more likely to conduct activities by following the predetermined rules and policies. They have power to execute their decisions (Bolman \& Deal, 1984, 1991c, 2003).

The human resource frame. Leaders using this frame view the organization much like an extended family that is comprised of individuals with needs, feelings, prejudices, skills, and limitations. A key challenge is how to tailor the organization to individuals. The thrust is on finding ways for people to accomplish tasks while feeling good about what they are doing. Within this frame, organizational members are viewed as the primary resource and only when these resources are the highest priority, can the organization improve its effectiveness. Human resource leaders try to build and maintain a harmonious relationship between the organization and individual. They seek to lead the organization through openness, participation, and empowerment (Bolman \& Deal, 1984, 1991c, 2003). 
The political frame. Leaders adopting the political frame see organizations as arenas of continuing conflict and competition for scarce resource among different groups with diverse agendas and interests. Political frame leaders view bargaining, negotiation, coercion, and compromise as normal occurrences in everyday organizational life. They are advocates and negotiators who value realism and pragmatism. They spend much of their time networking, creating coalitions, building a power base, and negotiating compromises (Bolman \& Deal, 1984, 1991c, 2003).

The symbolic frame. Leaders espousing the symbolic frame believe the world is chaotic, in which meaning and predictability are social creations, and facts are interpretative rather than objective. They provide a shared sense of mission and identity. Symbolic leaders instill a sense of enthusiasm and commitment through charisma and drama. They focus on myth, ritual, ceremony, stories, and other symbolic forms (Bolman \& Deal, 1984, 1991c, 2003).

Leadership style. The predominant pattern of leadership frame(s) and frame choice(s) perceived to be used by study participants as determined by a mean score of 4.0 or greater on the Leadership Orientation Survey by Bolman and Deal (1991a, 1991b).

The no-frame orientation leadership style. The chief state school officers who do not espouse any frame orientation are assumed to demonstrate a leadership style with no frame orientation (Bolman \& Deal, 1991a, 1991b).

The single-frame orientation leadership style. This leadership style indicates that a chief state school officer only uses a single frame (Bolman \& Deal, 1991a, 1991b).

The paired-frame orientation leadership style. A chief state school officer using any two of the four frames is designated to have this leadership style (Bolman \& Deal, 1991a, 1991b). 
The multi-frame orientation leadership style. The multi-frame orientation leadership style means that the chief state school officer espouses more than two frames (Bolman \& Deal, 1991a, 1991b).

Chief state school officer. The chief state school officer, either a Superintendent of Public Instruction, Education or Schools; Commissioner of Education; Secretary; or Director of Education is a constitutional or a statutory officer who is the chief executive official for the state's state education agency or equivalent, and chief administrative officer for the state's board of education or equivalent.

Educational governance model. The structure by which the chief state school officer and the state board of education are assigned to their respective positions.

Model one-educational governance. The governor appoints the members of the state board of education. The state board appoints the chief state school officer (Fultan, 2008).

Model two - educational governance. The state board of education is elected and the board appoints the chief state school officer (Fultan, 2008).

Model three - educational governance. The governor appoints the members of the state board of education. The chief state school officer is elected (Fultan, 2008).

Model four - education governance. The governor appoints both the state board of education and the chief state school officer (Fultan, 2008).

State education agency. A state education agency (SEA), or state department of education, is a formal governmental label for the state-level governmental agencies within each state responsible for providing information, resources, and technical assistance on educational matters to schools and residents. 


\section{Organization of the Dissertation}

Chapter One explains the research problem, the general background of the study, the professional significance of the problem, an overview of the methods utilized in answering the research questions, delimitations of the study, definitions of key terms, and organization of the dissertation.

Chapter Two presents relevant research related to leadership, the governance models that are used in each state and the District of Columbia, and the progression of the position of chief state school officer.

Chapter Three explains the proposed methods of the study. Survey research was the method used to answer the research questions. The final sections of Chapter Three describe how the questionnaire was disseminated, how the data were collected and analyzed, limitations involved in the process, and a summary of the proposed research method.

Chapter Four provides the analysis of the data collected during the study. Chapter Five presents the conclusions drawn from the study, as well as recommendations for further study. 


\section{Chapter Two: Review of Selected Literature}

This chapter reviews the major literature related to the variables of this study: the leadership styles of the chief state school officers and the models of educational governance. This chapter presents literature related to the development of the role and responsibilities of the chief state school officers, state models of educational governance, the study of leadership, and the conceptual framework used to determine the chief state school officers' leadership style. The chapter also includes related studies to support this research relative to Bolman and Deal's fourframe leadership orientation model, and leadership studies utilizing the Bolman and Deal framework of various educational leaders. The chapter concludes with a summary.

\section{A Historical Perspective of Chief State School Officers}

The Tenth Amendment to the United States Constitution reserved to the states all powers not specifically delegated to the national government, thereby having made public education a state responsibility. New York, in 1812, was the first state to establish the position of chief state school officer (First \& Quaglia, 1990; Sanchez \& Hall, 1987). Michigan, followed suit in 1829 and the remaining states created chief state school officer positions between 1830 and 1850 by constitutional provision or by state statue (First \& Quaglia, 1990; Harris, 1983).

According to Harris (1983), the position of chief state school officer initially was not prestigious; it was viewed primarily as a political office. The compensation chief state school officers received corresponded to the public perception. In $1937,81.2 \%$ of the chief state school officers were paid less than $\$ 7,000$ annually as compared to only $17.1 \%$ of state university presidents, and $34.8 \%$ of land-grant college presidents (Fuller \& Pearson, 1969). In 1950, the average salary for 48 chief state school officers was $\$ 8,271$, while the average salary for the highest paid city superintendents was \$13, 494 (Fuller \& Pearson, 1969). 
Table 1

Salaries of chief state school officers and highest paid city school superintendents in 1950

\begin{tabular}{|c|c|c|}
\hline State & Salary of Chief State School Officer & $\begin{array}{c}\text { Salary of City } \\
\text { Superintendent of Schools }\end{array}$ \\
\hline Alabama & $\$ 5,700$ & $\$ 9,250$ \\
\hline Alaska & data not available & \\
\hline Arizona & 5,500 & 12,412 \\
\hline Arkansas & 7,500 & 8,568 \\
\hline California & 12,500 & 25,000 \\
\hline Colorado & 6,000 & 18,500 \\
\hline Connecticut & 10,200 & 12,000 \\
\hline Delaware & 11,200 & 14,000 \\
\hline Florida & 10,000 & 10,000 \\
\hline Georgia & 7,500 & 12,000 \\
\hline Hawaii & data not available & \\
\hline Idaho & 4,000 & 9,000 \\
\hline Illinois & 9,000 & 25,000 \\
\hline Indiana & 7,500 & 15,000 \\
\hline Iowa & 6,500 & 15,000 \\
\hline Kansas & 5,000 & 12,000 \\
\hline Kentucky & 5,000 & 12,200 \\
\hline Louisiana & 10,000 & 12,500 \\
\hline Maine & 8,000 & 7,000 \\
\hline Maryland & 15,000 & 14,700 \\
\hline Massachusetts & 11,000 & 18,000 \\
\hline Michigan & 12,500 & 18,000 \\
\hline Minnesota & 8,000 & 18,500 \\
\hline Mississippi & 7,500 & 11,000 \\
\hline Missouri & 9,000 & 15,000 \\
\hline Montana & 4,200 & 8,200 \\
\hline Nebraska & 5,000 & 14,166 \\
\hline Nevada & 4,800 & 8,500 \\
\hline New Hampshire & 8,175 & 7,600 \\
\hline New Jersey & 15,000 & 18,000 \\
\hline New Mexico & 6,000 & 12,240 \\
\hline New York & 20,000 & 32,500 \\
\hline North Carolina & 7,500 & 12,000 \\
\hline North Dakota & 3,300 & 7,900 \\
\hline
\end{tabular}




\begin{tabular}{lrc}
\hline \multicolumn{1}{c}{ State } & Salary of Chief State School Officer & $\begin{array}{c}\text { Salary of City } \\
\text { Superintendent of Schools }\end{array}$ \\
\hline Ohio & 8,600 & 18,500 \\
Oklahoma & 4,800 & 15,000 \\
Oregon & 7,200 & 14,000 \\
Pennsylvania & 12,000 & 19,000 \\
Rhode Island & 6,000 & 13,950 \\
South Carolina & 7,500 & 10,500 \\
South Dakota & 4,800 & 8,000 \\
Tennessee & 7,800 & 10,713 \\
Texas & 17,500 & 16,500 \\
Utah & 6,000 & 10,500 \\
Vermont & 6,000 & 7,500 \\
Virginia & 9,960 & 14,000 \\
Washington & 8,500 & 12,900 \\
West Virginia & 6,000 & 8,600 \\
Wisconsin & 10,000 & 15,346 \\
Wyoming & 6,800 & 7,000 \\
Average salary & $\$ 8,271$ & $\$ 13,494$ \\
\hline
\end{tabular}

The initial scope of responsibility for chief state school officers was not extensive. Their primary functions were visiting schools, talking to teachers, preparing reports, interpreting school laws, and distributing state money (Fuller \& Pearson, 1969; Sanchez \& Hall, 1987). Keesecker (1950) had identified a list of responsibilities for early chief state school officers that included: interpreting and preparing plans for the improvement and management of the common school fund, reporting estimates and expenditures of the school monies and superintending the collection thereof, executing services relative to the sale of lands, giving information to the legislature, and generally performing all such services relative to the welfare of the schools (p. $10)$.

Subsequently, during the early 1900s, state departments of education did not employ many individuals, as there were only a limited number of functions to which to attend. Some state departments of education only consisted of the chief state school officer and one or two 
assistants (Fuller \& Pearson, 1969). According to Harris (1983), in 1900 there were only 177 members of state departments of education nationwide, including the chief state school officers.

The chief state school officers also were not accountable for significant sums of money. In 1900, the average per pupil expenditure was $\$ 11.51$ per student (Fuller \& Pearson, 1969). The average amount of public school revenue derived from state sources was approximately $\$ 44,000$, which corresponded to an average of $20.3 \%$ of the states' revenue (Fuller \& Pearson, 1969). Additionally, during this time period, the federal financial support for public school education was only approximately $0.3 \%$ of the annual budget for public education (Fuller \& Pearson, 1969).

According to the U. S. Census Bureau, in 1900 there were 21.6 million school-aged children between the ages of 5 and 17; however, many of those children did not attend school. Since not all of these children attended school, the chief state school officers were not responsible for educating those children or for providing a workforce to provide services to all those children.

\section{The Transitioning Role of Chief State School Officers}

During the 1900s, several significant events were instrumental in the amplification of responsibilities of the chief state school officers. The chief state school officers would become responsible for a greater educational budget; more individuals at state departments of education to administer programs; and for more school-aged children attending school.

One significant event, which broadened the scope of responsibility for the chief state school officers, was World War I. World War I increased the amount of federal monies that were allocated to states for vocational education and health and physical education (Fuller \& Pearson, 1969). The Smith Hughes Act of 1917, which was intended to promote vocational 
agriculture, also generated additional funding for vocational education programs (Fuller \& Pearson, 1969). World War II, the National Defense Education Act of 1958, the Vocational Education Act of 1963, and the Elementary and Secondary Education Act of 1965 all contributed to the mounting responsibilities of chief state school officers. The increased funding generated the need for personnel to administer the programs; therefore, the size of state departments of education continued to increase as did the level of responsibility of the chief state school officers.

As the $20^{\text {th }}$ century progressed and more complex educational programs were created, the number of children attending school increased, as did the expectations for students' educational attainment (Fuller \& Pearson, 1969). By 1964, there were approximately 44 million school-aged children (United States Department of Commerce, Bureau of the Census, 1962). Not only did the number of school-aged children grow, a greater percentage of those children were now attending school.

In response to this growth, the amount of fiscal resources dedicated to education expanded. By the mid 1900s, the average amount of revenue for public education was $\$ 9.6$ million, an increase of greater than $215 \%$ from the average in early the 1900 s (Fuller \& Pearson, 1969). Not only did the state fiscal involvement in education increase, the involvement of the federal government increased as well. Between 1900 and 1930, only .03\% of the monies designated for schools were derived from federal sources (Fuller \& Pearson, 1969). However, by 1966 , nearly three billion federal dollars were administered by state departments of education (Fuller \& Pearson, 1969). And by 1982, an average of $41.3 \%$ of the state education agency budgets were federally funded (Harris, 1983). 


\section{The Current Role of Chief State School Officers}

Campbell, Cunningham, Nystrand, and Usdan (1980) stated that the chief state school

officer exercises considerable control over education. According to Hansen and Morphet (1970), the primary responsibility of chief state school officers is to provide insightful and effective leadership in planning and conduct studies that provide the basis and rationale for proposing goals, policies, and priorities for the improvement of education in the state. The role of the chief state school officer has three primary components according to Harris (1983): 1) serving as executive officer of the state board of education, 2) serving as the administrative head of the state department of education and 3) serving as the chief administrative officer of the state for executing the laws, rules, and regulations relative to education. The chief state school officer influences state education policy, enlists grassroots support, recommends action to the state board of education, and influences the state legislature and governor as they consider educational problems (Cambell et al., 1980). Sanchez and Hall (1987) suggested that although the specific duties of the chief state school officers vary, the responsibilities may be clustered into four broad functions: an advisory function, a political function, an administrative function and a policymaking function.

While the establishment of the office of chief state school officer occurred more than 100 years ago and the primary purpose to create and sustain an educational system that produces well-educated school children has remained essentially the same, the societal context is vastly different and significantly more complex. Some of the mitigating factors that contribute to the complexity of the educational landscape are: higher expectations for student achievement, childhood poverty, international competition, limited fiscal resources, an increasingly diverse student population, and globalization coupled with a traditional, agrarian schedule. The position 
of chief state school officer is one with increasing complexity. The information in the following sections provide a more robust picture of the office of chief state school officer in present times.

Titles of chief state school officers. The chief state school officers of the United States and the District of Columbia have a variety of titles. According to the Council of Chief State School Officers (2011), they are referred to as commissioner, secretary, or director of education. They may also be titled superintendent of public instruction, of education, of schools, or solely superintendent. Additionally, they are also termed state superintendent of education, and state superintendent of schools.

Minimum qualifications. The qualifications that chief state school officers must possess vary, as widely do the titles of that position. According to Colasanti (2007), 12 states require the chief state school officer to be a U.S. citizen; 14 states have a minimum age requirement; 13 states have a residency prerequisite; 12 states have established a minimum level of education; 13 states require experience in education; and 11 require administrative experience. Arkansas, Nebraska, North Dakota, and Tennessee have identified licensure requirements; Alabama, Arkansas, Georgia, and West Virginia address the moral character of the chief state school officer; and Arkansas and Ohio address potential conflicts of interest. In 10 states, the minimum qualifications for the chief state school officer are established by the state board of education. Connecticut, Kansas, Massachusetts, New Jersey, New York, and Pennsylvania do not have qualifications for the chief state school officer. Table 2 identifies the categories of minimum qualifications by state for chief state school officers. 
Table 2

Minimum Qualifications for Chief State School Officers

\begin{tabular}{|c|c|c|c|c|c|c|c|}
\hline State & $\begin{array}{c}\text { U.S. } \\
\text { Citizen }\end{array}$ & Age & Residency & $\begin{array}{c}\text { Level of } \\
\text { Education }\end{array}$ & $\begin{array}{c}\text { Experience in } \\
\text { Education }\end{array}$ & $\begin{array}{c}\text { Experience in } \\
\text { Administration }\end{array}$ & $\begin{array}{c}\text { Determined by } \\
\text { State Board }\end{array}$ \\
\hline Alabama & & & & $\mathrm{X}$ & & $\mathrm{X}$ & \\
\hline Alaska & & & & $\mathrm{X}$ & $\mathrm{X}$ & $\mathrm{X}$ & \\
\hline Arizona & $X$ & $X$ & $X$ & & & & \\
\hline Arkansas & & & & $X$ & $\mathrm{X}$ & $\mathrm{X}$ & \\
\hline California & $\mathrm{X}$ & $\mathrm{X}$ & $\mathrm{X}$ & & & & \\
\hline Colorado & & & & & & & $\mathrm{X}$ \\
\hline \multicolumn{8}{|l|}{ Connecticut } \\
\hline Delaware & & & & $\mathrm{X}$ & $\mathrm{X}$ & $\mathrm{X}$ & \\
\hline Florida & & & & & & & $\mathrm{X}$ \\
\hline Georgia & $\mathrm{X}$ & $X$ & $\mathrm{X}$ & $\mathrm{X}$ & & & \\
\hline \multicolumn{8}{|l|}{ Hawaii } \\
\hline Idaho & $X$ & $X$ & $X$ & $\mathrm{X}$ & & & \\
\hline Illinois & & & & & & & $\mathrm{X}$ \\
\hline Indiana & & & $\mathrm{X}$ & & & & \\
\hline Iowa & & & & & $\mathrm{X}$ & $X$ & \\
\hline \multicolumn{8}{|l|}{ Kansas } \\
\hline Kentucky & & & & & & & $\mathrm{X}$ \\
\hline Louisiana & & & & & & & $\mathrm{X}$ \\
\hline Maine & & & & & & & $\mathrm{X}$ \\
\hline Maryland & & & & $\mathrm{X}$ & $\mathrm{X}$ & $X$ & \\
\hline \multicolumn{8}{|l|}{ Massachusetts } \\
\hline Michigan & & & & & & & $\mathrm{X}$ \\
\hline Minnesota & & & & & $X$ & & \\
\hline Mississippi & & & & $\mathrm{X}$ & & $\mathrm{X}$ & \\
\hline Missouri & $\mathrm{X}$ & & $\mathrm{X}$ & & & & \\
\hline Montana & & $\mathrm{X}$ & $\mathrm{X}$ & $\mathrm{X}$ & & & \\
\hline Nebraska & & & & $\mathrm{X}$ & $\mathrm{X}$ & $\mathrm{X}$ & $\mathrm{X}$ \\
\hline Nevada & & $\mathrm{X}$ & & $\mathrm{X}$ & & & \\
\hline New Hampshire & & & & & $\mathrm{X}$ & & $\mathrm{X}$ \\
\hline \multicolumn{8}{|l|}{ New Jersey } \\
\hline New Mexico & & & & & $\mathrm{X}$ & & \\
\hline New York & & & & & & & \\
\hline
\end{tabular}

(continued) 


\begin{tabular}{|c|c|c|c|c|c|c|c|}
\hline State & $\begin{array}{c}\text { U.S. } \\
\text { Citizen }\end{array}$ & Age & Residency & $\begin{array}{l}\text { Level of } \\
\text { Education }\end{array}$ & $\begin{array}{c}\text { Experience in } \\
\text { Education }\end{array}$ & $\begin{array}{l}\text { Experience in } \\
\text { Administration }\end{array}$ & $\begin{array}{c}\text { Determined by } \\
\text { State Board }\end{array}$ \\
\hline North Carolina & & $\mathrm{X}$ & $\mathrm{X}$ & & & & \\
\hline North Dakota & $X$ & $X$ & $X$ & & & & $\mathrm{X}$ \\
\hline \multicolumn{8}{|l|}{ Ohio } \\
\hline Oklahoma & $X$ & $X$ & $X$ & & & & \\
\hline Oregon & $\mathrm{X}$ & $\mathrm{X}$ & $\mathrm{X}$ & & & & \\
\hline \multicolumn{8}{|l|}{ Pennsylvania } \\
\hline Rhode Island & & & & & & & $X$ \\
\hline South Carolina & & $\mathrm{X}$ & & & & & \\
\hline South Dakota & & & & & & $\mathrm{X}$ & \\
\hline Tennessee & & & & & $X$ & $X$ & \\
\hline Texas & $\mathrm{X}$ & & & & & & \\
\hline Utah & & & & & & & $X$ \\
\hline Vermont & & & & & $X$ & & \\
\hline Virginia & & & & & $X$ & & \\
\hline Washington & $\mathrm{X}$ & $X$ & & & & & \\
\hline West Virginia & & & & $\mathrm{X}$ & $\mathrm{X}$ & $\mathrm{X}$ & \\
\hline Wisconsin & $\mathrm{X}$ & $\mathrm{X}$ & $X$ & & & & \\
\hline Wyoming & $\mathrm{X}$ & $X$ & $X$ & & & & \\
\hline
\end{tabular}

Note. Adapted from "Qualifications for Chief State School Officers" by M. Colasanti, 2007 Education Commission of the States. Copyright 2007 by Education Commission of the States. Reprinted with permission.

In 1969, Fuller and Person delineated a set of personal characteristics that would be essential for a chief state school officer, "administrative integrity and ability, diligent and dedicated work, courage and candor in action, and relative emphasis on performance in fundamentally important but difficult areas of leadership". ..(p. 93). Joseph Pittenger, former Secretary of Education in Pennsylvania from 1972 to1977 identified the following as being the essential characteristics for being a good chief state school officer in Murphy (1980):

You've got to be a manager when you're chief; that's clearly one thing that's involved. You've also got to be a politician. You've got to understand what the forces are out there and who has what kind of clout, and what kind of trade-offs people will accept. Third, it's helpful to have a persona, a style, a sense of your office and your position to allow 
you to provide some leadership rather than just respond to forces. And I think you have to have some convictions. . I think if a chief were a good manager, good politician, a charismatic person, and a person with strong convictions that would be pretty good. ( $\mathrm{p}$. 131)

Fiscal responsibility. The chief state school officers are responsible for a significant amount of money, both from the state government and from the federal government. According to the National Association of State Budget Officers, in fiscal year 2011 funding for elementary and secondary education expenditures accounted for $20.2 \%$ of the average state expenditures for a total amount of $\$ 67.7$ billion. The expenditures for elementary and secondary education constituted the largest share of the states' general fund. According to statistics from the National Association of State Budget Officers, approximately $66.5 \%$ of the state's general fund was dedicated to elementary and secondary education (National Association of State Budget Officers, 2012).

The money used to provide a free and appropriate education to the school-aged children of the state does not all derive from state government sources. The federal government allocates federal dollars to state education agencies. In the 2009 fiscal year, the federal government distributed 36.6 billion dollars to state education agencies for all elementary and secondary level programs (United States Department of Education, 2009).

Relationship with state legislature. State statute articulates the various components of the educational system for the respective state. The chief state school officers are responsible for executing the laws and regulations relative to education. However, the chief state school officers' responsibility is not only to execute the statues related to public school, they have an influential role in the modification of existing laws and the creation of new ones. The chief state 
school officers are in a crucial position to provide information to legislators so that they in turn may enact new education law and make necessary changes to existing laws. According to Fuller and Pearson (1969),

Effective chief state school officers and their staffs always have done far more than provide information to the legislature and to promote harmony. They have recommended needed improvements, worked with interim study committees and councils, testified before legislative agencies, conferred in depth with individual legislation leaders, and given leadership to positive programs in cooperation with lay and professional individuals throughout the states they serve. (p. 113)

State legislatures, in conjunction with the governor, determine the resources that are allocated to state departments of education and to public education in general. The education budget is in competition with other state departments for limited resources. Fuller and Pearson (1969) said that in the environment of competition, "the education department, - its image and its budget- is sensitive and vulnerable" (p. 112).

Education is an essential governmental service. As mentioned previously, the average state expenditures for elementary and secondary education were $20.2 \%$ of the total state expenditures, and $66.5 \%$ of general fund spending, according to the National Association of State Budget Officers (2012). The chief state school officers have a fiscal relationship with and fiscal responsibility to the state legislature.

Human resource responsibility. The chief state school officers are accountable to a significant workforce affiliated with public, K-12 education. According to the United States Census Bureau (2012), in 2010 over 11.1 million people were employed full-time in an Elementary or Secondary Education capacity nationwide. The number of school-aged children 
in 2010 was approximately 53.4 million school-aged children between the ages of 5 and 17, a number that corresponded to $18.2 \%$ of the total population in 2010. (United States Census Bureau, 2011).

Social responsibility. The chief state school officers are responsible for the quality of the educational system and for facilitating the academic progress of the school aged children of the state. The No Child Left Behind Act of 2001 is one of the most prominent metrics used to make judgments about the quality of the education system within the state and the guide used to determine if all students are making progress toward mastery of state identified standards and skills. "Education is increasingly perceived to be both the problem and the solution, both an individual cost and a benefit as a positional good, and both a public expense and source of income through its commodification" (Blackmore, 2002, p. 199). The education of the populace is an enormous responsibility with far reaching impact.

Social justice and equity continue to increase in importance as globalization creates new, or exacerbates old forms of inequality influenced by race, gender, class, and ethnicity (Gewirtz, 1998). This increase of importance is driven by many factors, including the growing diversity of society and the school-age population, the growing awareness of the achievement and economic gaps between children, and the increasingly sophisticated analyses of social injustice as played out in schools, including those that may arise from the high-stakes accountability movement (Furman \& Gruenewald, 2004). Indeed, educational leadership is needed to navigate the turbulent waters.

The position of chief state school officer has transitioned from its initial inception in the early 1900 s until modern times. And while there is overlap in the activities and duties that were initially required to the activities and duties that are now required, the weight of those 
expectations is substantially greater today. Along with the increase of funding for public education, an increase in the number of individuals affiliated with public education, and an increase in the number of school-aged children attending school, is a significant shift in the depth and breadth of the responsibilities of chief state school officers. The expectation of chief state school officers to create and sustain an educational system that produces well-educated school children is more challenging than it was at the time the position was created. The realization of the expectations is more challenging for multiple reasons; international competition, limited fiscal resources, a highly diverse student population, a greater percentage of students living in poverty, increasing demands for an educated workforce, and technological innovations, among other reasons. To date, very little scholarly research has been conducted on the population of chief state school officers.

\section{Historical Perspective of State Models of Educational Governance}

The variety among titles of chief state school officers and minimum qualifications for the position, mirror the variety of state governance models used to articulate how chief state school officers are selected. Since the 1900s, five primary methods have been utilized (Fuller \& Pearson, 1969). Those methods have been: election by the people, appointment by the governor, appointment by the state board of education, appointment by the state legislature, and an ex officio designation. However, states have neither been uniform or consistent in their method of selecting a chief state school officer (Fuller \& Pearson, 1969).

The selection of a chief state school officer by the state legislature was not used pervasively. In 1900, three states employed this method and by 1910 only one state continued the practice. After 1919, there is no record of selection by this means. According to Fuller and 
Pearson (1969), the selection of the chief state school officer by this manner was perceived to be an invasion of the executive branch and a denial of the electorate.

The method of selection by ex officio designation was likewise in limited use. In 1900, one state used this method and by 1910 this method was also discontinued. The ex officio designation, in effect made a person who had been elected, on a non-educational platform, the part-time chief state school officer (Fuller \& Pearson, 1969).

The method of selecting a chief state school officer by state board of education appointment grew from three states using this method in 1900 to 28 states using this method in 1982 (Fuller \& Pearson, 1969; Harris, 1983). Appointment of the chief state school officer by the governor was the method of selection in 7 states in 1900. The number of chief state school officers appointed by this method grew by one state in 1940 and declined to 4 states in 1967 (Fuller \& Pearson, 1969).

The most common method by which to select a chief state school officer was by popular election. In 1900, 31 states elected a chief state school officer. The citizenry had placed the position of chief state school officer in the state constitution as a way to insulate the office from abolition and to give the office authority (Fuller \& Pearson, 1969; Will, as cited in Sanchez \& Hall, 1987). Within a majority of state governments in the $19^{\text {th }}$ century, the designation of the position of chief state school officer in the state constitution placed the position in a higher status than may have been granted without the placement in the constitution (Fuller \& Pearson, 1969). The frequency of selection by popular election declined to 22 states in 1967 and by 1982, 18 states elected the chief state school officer. Of those 18 states, 13 states elected the chief state school officer by a partisan ballot (Harris, 1983). 


\section{Current Models of State Educational Governance}

In 2010, there were 4 primary models of state governance (Fultan, 2008). This section of Chapter 2 will describe the components of the different models, identify the states utilizing each of the models, and present the states that have been added to the model category based on educational governance similarities for the purpose of research and analysis. Additionally, several pros and cons of each model will be presented.

In Model One, chief state school officers are appointed by the state board of education, which is appointed by the governor. There are 14 states in this category: 12 states that utilize this model exclusively, Alaska, Arkansas, Connecticut, Florida, Illinois, Kentucky, Maryland, Massachusetts, Missouri, Rhode Island, Vermont, and West Virginia and two states that have been added based upon similarities with the educational governance systems: Mississippi and New York.

Proponents of this model of governance attest that a board appointed chief is more likely to have a nonpartisan position in relation to politics and may be regarded as more of an educator and less like a political figure (Harris, 1973, 1983). Another stated conviction for the benefits of this model is the belief that a policy generating board would be able select a chief state school officer and hold the individual accountable for policy implementation and policy revision (Harris, 1973, 1983). In addition, the state board of education is perceived to be ideally suited, better than the general public, to select a competent and well-qualified individual for the position (Harris, 1973, 1983; Lewis, 1983). O’Shea (1976) found in a survey about preferences of educational governance models that of the 432 respondents, $28.5 \%$ preferred this model of educational governance. Additionally, O’Shea (1976) found that $76.3 \%$ of educational leaders were more satisfied with this model than with any other. 
According to Harris (1973), there are two possible disadvantages to this selection model. First, the possibility exists that the board of education is not a competent board and would select an incompetent and irresponsible chief state school officer. The second potential detractor from this method is the potential perception that a board appointed chief weakens the executive office control of education or that education policy and governance is too far removed from the state political process. Figure 1 illustrates the method of selection of chief state school officers in Model One states, and the states that currently use this model of educational governance. 
Figure 1

State Governance: Model One

Model One: Governor Appoints Board, Board Appoints Chief

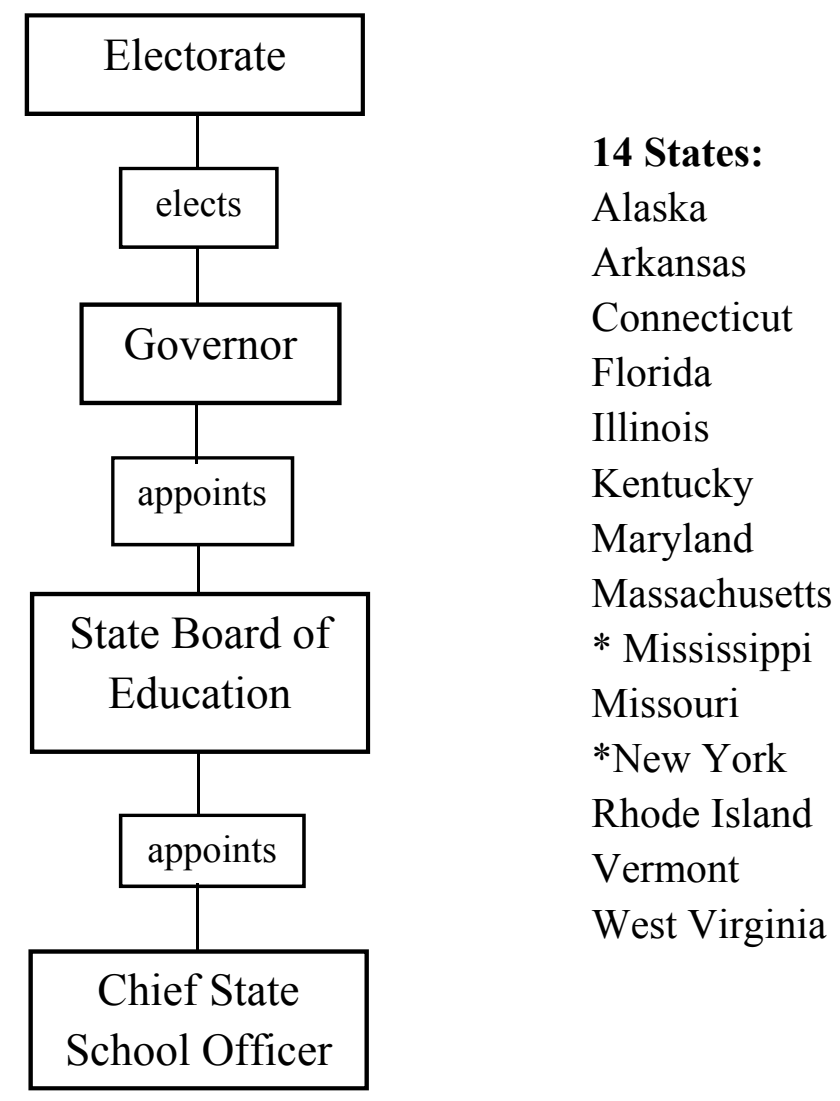


Educational governance Model Two is similar to Model One in that the state board of education appoints the chief state school officer. However, in Model Two, rather than being appointed by the governor, the state board of education is elected. Currently, 10 states are governed in this manner, eight states that utilize this model exclusively: Alabama, Colorado, Hawaii, Kansas, Michigan, Nebraska, Nevada, and Utah and two states that have added based upon similarities with the educational governance systems: Louisiana and Ohio.

The nature of this method of selection somewhat removes control of education from the auspices of the executive branch; there is no direct line of administrative leadership between the governor and the chief state school officer. A state board of education that is elected by the people is independent from the governor.

O’Shea's (1976) research revealed a comparable satisfaction rate with this method, $21.8 \%$ favored this model when compared to the overall satisfaction, $28.5 \%$, with Model One. Although, only $56.5 \%$ of the educational leaders using this model were satisfied, as compared to a $76.3 \%$ satisfaction rate with Model One.

However, there are fundamental concerns with the election of state board members. The political campaign for the position of state board of education member could be reduced to emotional, irrational, and non-education related issues. Similar to the concerns addressed with an appointed board, an elected state board of education does not necessarily guarantee a competent and functional board of education. Figure 2 illustrates the method of selection of chief state school officers in Model Two states, and the states that currently use this model of educational governance. 
Figure 2

State Governance: Model Two

Model Two: Elected Board, Board Appoints Chief

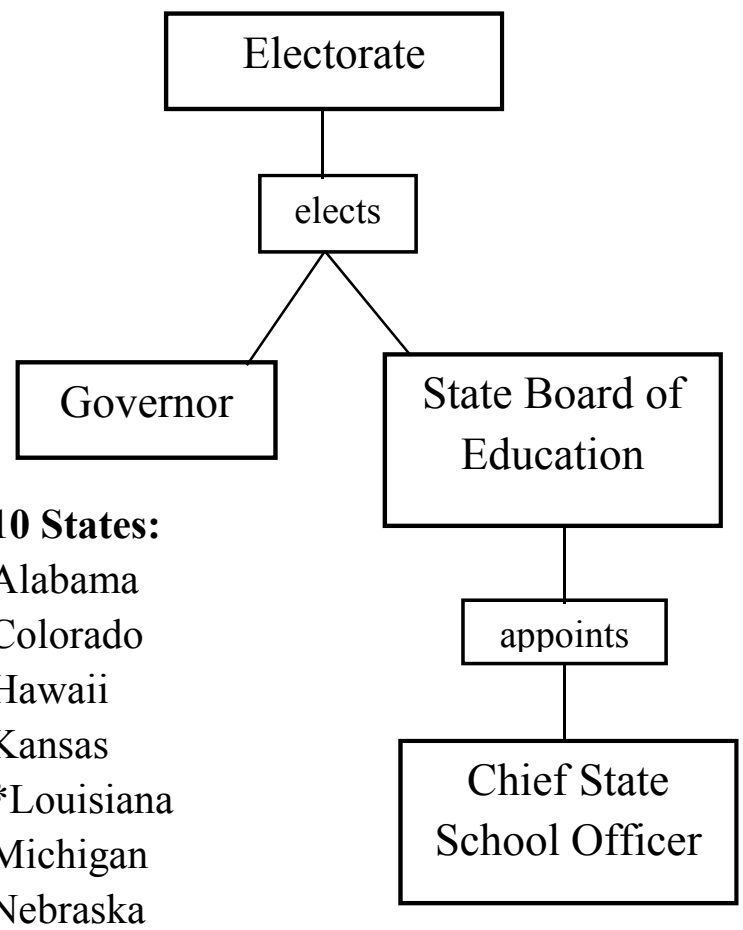

*Ohio

Nevada

Utah 
In Model Three, the governor appoints the members of the state board of education and the chief state school officer is elected. Currently, 14 states have chief state school officers who are elected, 11 states that utilize this model exclusively: Arizona, California, Georgia, Idaho, Indiana, Montana, North Carolina, North Dakota, Oklahoma, Oregon, and Wyoming and three states have been added based upon similarities with the educational governance systems: South Carolina, Washington and Wisconsin.

Proponents of the model in which chief state school officers are elected, posit that an elected official represents the will of the majority of voters and in turn will be responsive to them (Harris, 1983). Other assertions about the benefits of an elected chief include, the theory if the chief is elected by a partisan ballot, the chief state school officer would appear to have the support of their party and thus able to make significant changes in education. Consequently, election by popular vote could yield considerable influence with other elected officials. Finally, an individual who is elected will be familiar with the educational context of the state. Dolores Colburg, Superintendent of Public Instruction in Montana from 1969-1976 responded to the question regarding the advantages to being an elected chief in Murphy (1980) by saying, It was helpful with respect to the Legislature on those issues - which I would carefully pick and choose - on which I would personally testify. My mere presence was a reminder that I too, like them was elected. . . It was helpful to not be subservient to a governor or to a state Board of Education. I could go directly to the people, as in the campaign, meeting with various groups and laying before them what I wanted to accomplish as state superintendent. (p. 86)

Critics of this method of selection state that the selection of the chief state school officer could be negatively influenced by party politics on state education policy (Harris, 1973). 
Another critique of the method states that the educational issues could be reduced to emotional and irrational influences during a political campaign (Harris, 1973). Additionally, no person from outside of the state is eligible for the position. Opponents of Model Three argue that political savvy may be more important than educational experience for election, but the lack of educational experience could be a hindrance once in the position. Sanchez \& Hall (1987) suggest that the more qualified candidates may not want to submit to the rigors of political campaigning.

Colburg, said of the disadvantages of being an elected chief, The time and the business of raising money. . .I had to do a great chunk of fund-raising myself, and that's demanding for any candidate. Another disadvantage is that people could say, "Oh, that's just a political position." Finally, if one looks across the country, elected chiefs are paid notably less than appointed ones. (p. 86)

Figure 3 illustrates the method of selection of chief state school officers in Model Three states, and the states that currently use this model of educational governance. 
Figure 3

State Governance: Model Three

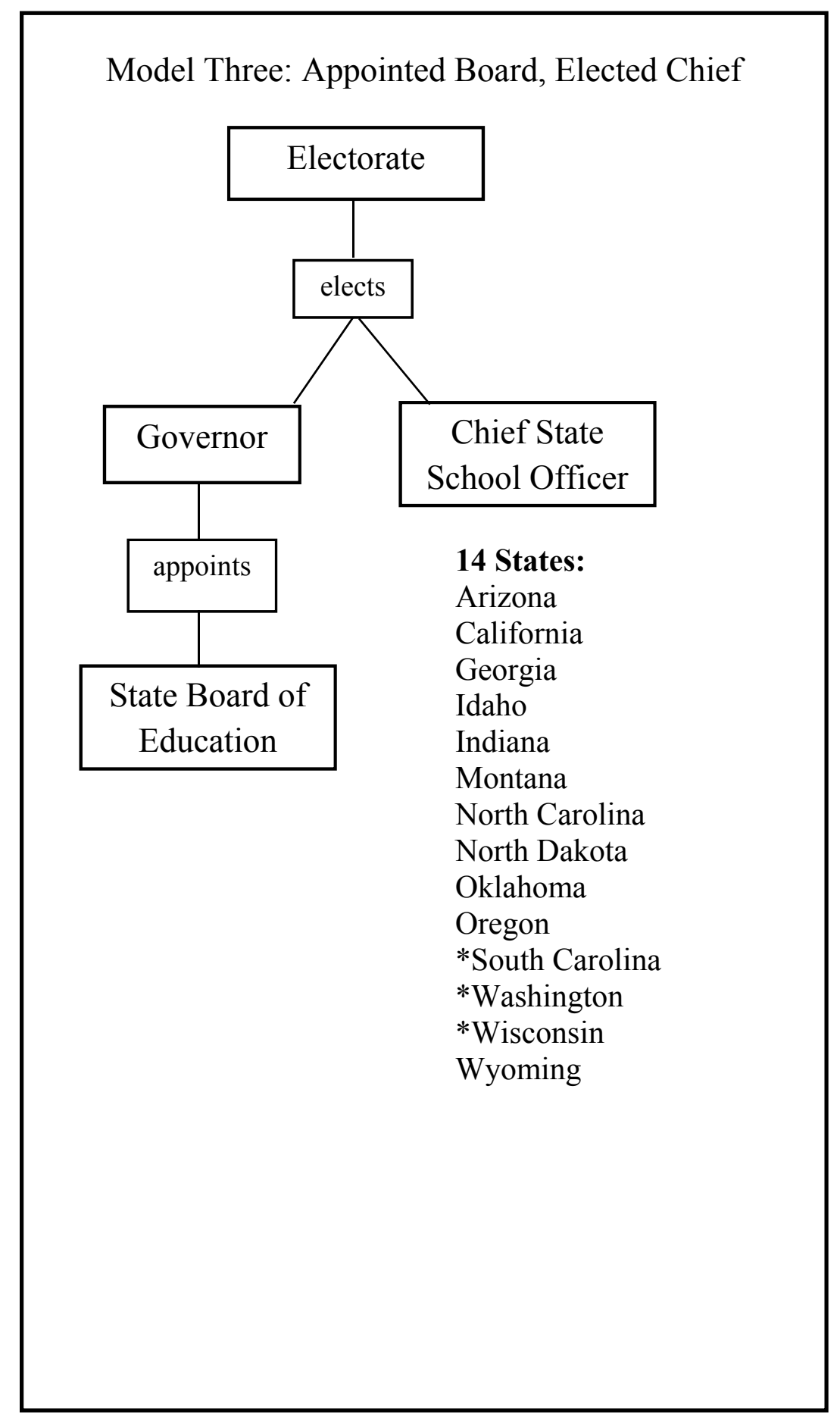


In Model Four, the governor appoints both the state board of education and the chief state school officer. Currently, 13 states employ a chief state school officer by appointment by the governor, nine states are governed in this manner: Delaware, Iowa, Maine, New Hampshire, New Jersey, Pennsylvania, South Dakota, Tennessee, and Virginia and three states have been added based upon similarities with the educational governance systems: Minnesota, New Mexico, and Texas, and the District of Columbia has also been added.

Strong advocates for this method of appointment attest that when the governor appoints the chief state school officer, it may be assumed that education will have the support of the governor. In other words, a gubernatorial appointment facilitates the coordinated delivery and control of education (Harris, 1983).

However, appointment by the governor makes the chief state school officer politically dependent on the governor (Fuller \& Pearson, 1969). The chief state school officer may benefit from the governor's positive influence on education or suffer as a result of a governor's either lack of enthusiasm for education or as a result of the legislature's dissatisfaction with or opposition to the governor's programs (Fuller \& Pearson, 1969; Harris, 1973). Figure 4 illustrates the method of selection of chief state school officers in Model Four states and the states that currently use this model of educational governance. 
Figure 4

State Governance: Model Four

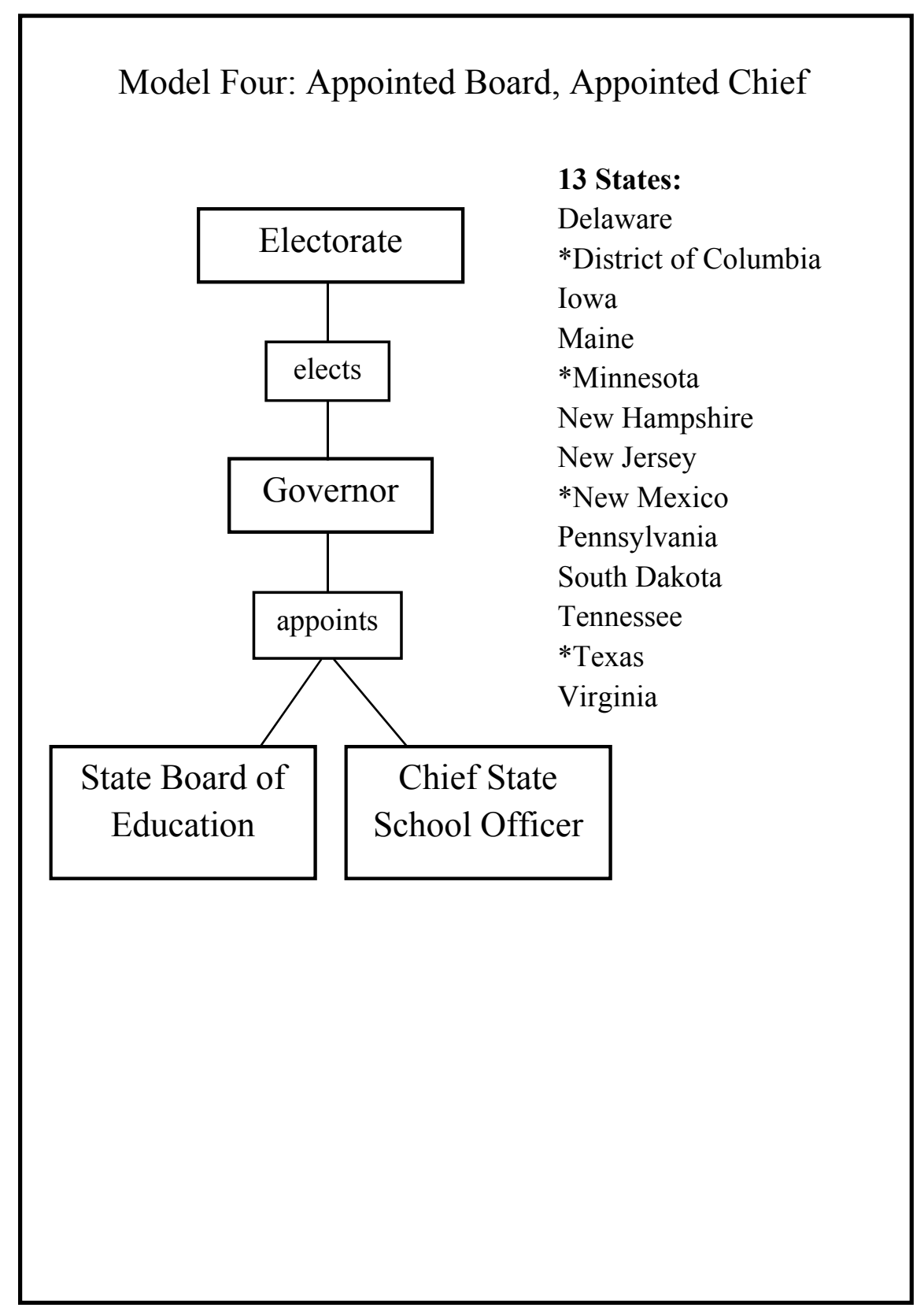


The remaining 10 states and the District of Columbia have state governance models that do not fit discretely into one of the four models of governance (Fultan, 2008); they subscribe to modified versions of the models. In Louisiana, there are a total of 11 board of education members. Of those 11, eight members are elected whereas the governor appoints three members. In Ohio, a similar configuration is used, 11 board members are elected and the governor appoints eight members.

The state legislature has a role in appointing the members of the board in New York and also in South Carolina (Fultan, 2008). In New York, all the members of the board are appointed by the legislature and the board appoints the chief state school officer. In South Carolina, similarly, the legislature appoints all the board members; however; the chief state school officer is elected.

In Mississippi, the responsibility for the appointment of board members is divided among three entities, the governor, the lieutenant governor, and the Speaker of the House. The board then in turn appoints the chief state school officer.

In Washington, there is a conglomeration of board members. Of the 16 members, five are elected by either district directors, one member is elected by a board of directors of a stateapproved private school, seven members are appointed by the governor, two are student members, who are non-voting members, and the chief state school officer.

In Texas, the governor appoints the chief state school officer; however; the state board is elected. New Mexico does have an elected entity, the Public Education Commission; however, this body serves only in an advisory capacity. Two states, Minnesota and Wisconsin, and the District of Columbia do not have state boards of education. Both in Minnesota and New Mexico, the governor appoints the chief state school officer. In Wisconsin, the chief state school officer 
is an elected official. The state board of education in the District of Columbia serves only in an advisory capacity.

For the purposes of this study, the states that do not fit discretely into one of the four models of educational governance were placed in the model that most closely aligned with the identified governance configuration. As discussed earlier, Mississippi and New York were placed in Model One because the state board of education members are appointed. Louisiana and Ohio were placed in Model Two because the majority of the board members are elected. South Carolina, Washington, and Wisconsin were placed in Model Three because the chief state school officer is an elected official. The District of Columbia, Minnesota, New Mexico, and Texas were placed in Model Four because the chief state school officer is appointed to the position.

According to Fuller and Pearson (1969), there was a paucity of objective measures by which to evaluate the relative merits of any one state governance models. The specific organizational patterns and administrative devices could not ensure the success of the chief state school officer or of the departments of education for which they were the administrative head (Harris, 1973). Fuller and Pearson (1969) stated,

There have been both successful and unsuccessful chief state school officers under all leading systems of organizations and administration, perhaps because the best system cannot itself make an incompetent person successful and the worst system cannot prevent success by the most competent. (p. 98)

Regardless of the method of selection, the chief state school officer functions in a political capacity. The four former chief state school officers interviewed in Murphy (1980) all mentioned the need for chief school officers to have the ability and skill to operate in the 
political sphere. Campbell and Mazzoni (1976) stated, "political skills seem essential if the chief is to influence the governor and the legislature" (p. 271). However, not only is there a lack of research regarding state models of education governance, the only apparent research is the work by O'Shea (1976), there is also a scarcity of data about chief state school officers and in particular their leadership styles. Data about chief state school officers are important. Chief state school officers are in positions of leadership with a great responsibility, fiscal, human resource, and social responsibility. The leadership framework from which the chief state school officer operates has an impact on the manner by which they execute the responsibilities of the office.

\section{Study of Leadership}

Leadership effectiveness has been the subject of extensive research. Yukl (2002) concluded "leadership is a social process in which a member or members of a group or organization influence the interpretation of internal and external events, the choice of goals or desired outcomes, organization of work activities, individual motivation and abilities, power relations and shared orientations" (p. 375). "The process of directing and influencing subordinates is important. .." (Yukl, 1982, p. 3). However, the manner by which the concept of leadership effectiveness has been studied has varied (Yukl, 1982, 2006). The researchers' conception of leadership, their definition of effectiveness, and methodological preferences influence the design and the outcome of the study (Yukl, 1982). The numerous studies on leadership may be categorized into six distinct approaches: the Trait Approach, the PowerInfluence Approach, the Behavior Approach, the Situational or Contingency Approach, Transformational Leadership, and Charismatic or Symbolic Leadership. 
The trait approach. The Trait Approach was one of the earliest frameworks for studying leadership (Yukl, 1982, 2006). The operating assumption of this paradigm was that there were specific characteristics and traits that were predictors of leadership and leadership effectiveness (Yukl, 1982, 2006). According to Bass (1981), in the early 1900s, leaders were esteemed as superior individuals, whose fortune or social circumstance separated them from the general public. Until the 1950s, the preponderance of studies on leadership sought to discover the trait differences between leaders and followers (Hoy \& Miskel, 2005;Yukl, 1982).

Stogdill (1948), in early trait research, reviewed the results of 124 trait studies conducted between 1904 and 1947. His meta-analysis of the trait studies concluded that a set of specific traits failed to correlate with leadership in a strong or consistent manner. Additionally, in Miner's (2005) analysis of the earlier trait studies, a similar conclusion was reached; a set of specific traits did not consistently correlate to a distinction from leaders and non-leaders.

The early trait research was negatively affected by methodological deficiencies and by the architecture of the studies that did not give significant attention to the leadership context and its impact on the relevance and the relative or fixed priority of different traits (Yukl, 1982). Additionally, in those early studies, how a specific trait or set of traits interacted with or was influenced by either or both the personality and the behavior of the leader was also neglected. (Yukl, 1982, 2006)

In spite of the lack of conclusive evidence regarding the trait approach, research persisted. Industrial psychologists, whose focus was on improving managerial selections, continued to conduct research utilizing this paradigm (Yukl, 2006). However, an attempt to redress some of the identified deficiencies from the earlier studies was made by industrial 
psychologists through the use of improved measurement procedures, use of longitudinal studies, and examination of trait patterns (Hoy \& Miskel, 2005; Yukl, 1982, 2006).

The second generation of trait approach studies yielded a more conclusive set of findings (Hoy \& Miskel, 2005). Stogdill (1974) completed another meta-analysis of trait approach research, which identified the following traits of an effective leader:

... a strong drive for responsibility and task completion, vigor and persistence in pursuit of goals, venturousness and originality in problem solving, drive to exercise initiative in social situations, self-confidence and sense of personal identity, willingness to accept consequences of decision and action, readiness to absorb interpersonal stress, willingness to tolerate frustration and delay, ability to influence other persons' behavior, and capacity to structure interaction systems to the purpose at hand. (p. 379)

In summary, the second generation of research on the relationship between the trait approach and leadership effectiveness did yield results that posited that the possession of certain traits increased the likelihood that the leader would be effective (Yukl, 2006). Table 3 identifies the traits and skills that are associated with effective leadership.

Table 3

Traits and Skills Associated with Effective Leadership

\begin{tabular}{lll} 
Personality & Motivation & Skills \\
\hline Self-confidence & Task and interpersonal needs & Technical \\
Stress tolerance & Achievement oriented & Interpersonal \\
Emotional maturity & Power needs & Conceptual \\
Integrity & Expectations & \\
\hline
\end{tabular}


The power and influence approach. According to Yukl (1982), "the effective use of power by a leader requires both the ability to diagnose the situation and determine what influence strategy is appropriate and the ability to exercise the appropriate form of power in a manner that leads to subordinate commitment" (p. 11). According to Yukl, (1982) the research regarding power and the effectiveness of the leader has attempted to answer two broad questions: How do effective leaders accumulate power and how do they exercise power to influence follower commitment?

French and Raven (1959) identified 5 types of power in their power typology: reward power, coercive power, legitimate power, expert power, and referent power. Reward power stemmed from the leader's ability to distribute rewards to the subordinate while the subordinate did something in order to obtain those rewards. Coercive power was present when the subordinate did something in order to avoid punishments controlled by the leader. Legitimate power was present when the subordinate did something because the leader had the right to request it and the subordinate had the obligation to comply. Expert power was possessed when the subordinate did something because they believed that the leader had special knowledge and expertise lacked by the subordinate. Referent power was displayed when the subordinate did something because they admired the leader and wanted to gain the leader's approval. Raven (1965) added a sixth type of power to the power typology: informational power. Informational power was possessed when the leader provided persuasive material or logical reasoning and the subordinate understood and accepted the reasons and changed their behavior.

The power that the leader possessed emanated from two sources, personal power - the leader's own individual characteristics and positional power - the power that was generated from the leadership position (Yukl, 1982). Social Exchange Theory (Hollander, 1980; Jacobs, 1970) 
attributed the amount of status and influence a leader had to the followers' assessment of the leader's potential contribution. The areas of contribution may have included the leader's ability to collect/manage scarce resources, to access important information or to expertly manage critical problems (Yukl, 1982). The amount of power that was given to the leader by followers was proportional to their assessment of the leader's ability to affect critical contribution areas, which were important to the followers (Yukl, 1982).

A new formulation was proposed by Raven (1992, 1993), the Power/Interaction Model of Interpersonal Influence, in response to several conceptual and methodological issues raised in the literature (Hinkin \& Schriesheim, 1989) In this model, the original bases were further differentiated into 11 power bases. Coercion and reward were further divided into impersonal coercion: the threat of punishment, personal coercion: the threat of disapproval or dislike, impersonal reward: a promise of monetary or non-monetary compensation and personal reward: a promise to like or approve. Also, four types of legitimacy were identified: reciprocity: the request is based on the agent having done something positive for the target, equity: the request is based on compensating for either (a) hard work or sufferance by the agent or (b) harm inflicted by the target, dependence: the request is based on social responsibility to assist another who is in need and position: the request is attributed to the right one has because of status or position. (Raven, 2008; Schwarzwald, Koslowsky, \& Brody-Shamir, 2006)

One of the critiques of the research related to the Power and Influence Approach has been that the skills and behavior of the leader in exercising power did not appear to have been considered in the research questions (Yukl, 1982). Yukl $(1982,2006)$ posited that the results of a leader's attempt to exert influence depended as much on the leader's skill as on the type and amount of power possessed by the leader. 
The behavior approach. According to Yukl (1982, 2006), a preponderance of the research on leadership behaviors focused on either describing the nature of the work, or in identifying the differences in behavior between identified effective leaders and ineffective leaders.

The data about the nature of the work of leaders typically were collected through selfreport journals or through observation. Although this element of descriptive research was not directly linked to the study of leadership effectiveness, it was believed that an understanding of the tasks would assist in identifying the necessary skills and behaviors required for one to be successful at those tasks (Yukl, 1982).

Mintzburg (1973) reviewed the research from earlier studies, in addition to results from his own studies, and concluded the work of managers included a wide variety of activities that could be primarily characterized by brevity and fragmentation. He also concluded that managers gravitated toward the aspects of the position that were active. Mintzburg (1973) proposed that an individual's effectiveness could be improved if less time was spent on superficial activities and more time on those less active functions such as planning and organizing; follower development; and team building.

One limitation Mintzburg (1973) discovered in the earlier behavioral traits studies was that the descriptive research of the leader's activities was limited only to descriptions at a very concrete level. There was no categorization of the behavior in a functional sense. He posited that without the functional component of those activities, data about what a leader does could not be collected. To address the identified deficiencies, Mintzberg (1973) created functional roles by which to classify the behavior of the leader. Those roles were: figurehead, leader, liaison, 
monitor, disseminator, spokesperson, entrepreneur, disturbance handler, resource allocator, and negotiator.

Even with the addition of Mintzberg's functional roles, which had provided a more accurate description of what managers did, Yukl $(1982,2006)$ suggested that descriptive research did not identify the behaviors required for managerial effectiveness. Yukl (2006) stated that the majority of managerial activities may be grouped into one of four categories: (1) developing and maintaining relationships, (2) obtaining and providing information, (3) making decisions, and (4) influencing people (p. 41).

While self-reporting journals and observation had been two methods by which to gather data about the behaviors of leaders, the most frequent method had been the use of questionnaires to describe the behavior (Yukl, 1982). The typical approach was to compare the behavior patterns of effective leaders with ineffective leaders (Yukl, 1982). To verify the responses of the leader, data about the leader's effectiveness was collected from the followers or from superiors.

The leadership questionnaire research methods have been heavily influenced by the leadership studies conducted by Ohio State University in the early 1950's (Yuk1, 1982). The researchers identified two broadly defined categories of leadership behavior and labeled them consideration and initiating structure. Questionnaires were then developed to measure these behaviors. Consideration was described as "leader behavior that indicates friendship, trust, warmth, interest, and respect in the relationship between the leader and members of the work group" (Halpin, 1957, p. 42). Initiating structure was "any leader behavior that delineates the relationship between the leader and the subordinates and, at the same time, establishes defined patterns of organization, channels of communication, and methods of procedure" (Hoy \& Miskel, 2005, p. 386). 
Although the studies that were generated from Ohio State University had a significant impact on the design and conceptual framework for many subsequent studies, the results were inconsistent (Yukl, 1982, 2006). The only significantly consistent finding was that followers were generally more satisfied with a leader who was highly considerate (Yukl, 1982, 2006). The research conducted by the University of Michigan in the 1950's yielded more consistent findings (Likert, 1961, 1967). The use of interview and questionnaires yielded results that indicated that effective managers tended to concentrate on administrative functions such as planning, coordinating, and facilitating work when the behavior patterns of effective and ineffective leaders were compared (Yukl, 1982).

Additionally, effective managers were able to complete task-oriented functions without neglecting interpersonal relationships with followers (Yukl, 1982, 2006). The followers of effective leaders reported that they were treated in a considerate, supportive manner, and were given some autonomy in deciding how to do their work (Yukl, 1982, 2006). Effective leaders set high performance goals for followers, used group methods of supervision, and served as a linking pin with other groups and with higher management, according to the conclusions from the University of Michigan studies (Yukl, 1982, 2006).

Yukl (2006) developed a framework to integrate the behavioral typologies and taxonomies. The three broad categories of behavior were described as task-oriented behaviors, relations-oriented behaviors, and change-oriented behaviors. Task-oriented behaviors encompassed clarifying roles, planning and organizing operations, and monitoring organizational functions. Relations-oriented behaviors included supporting, developing, recognizing, consulting, and managing conflict. Change-oriented behaviors consisted of scanning and interpreting external events, articulating an attractive vision, proposing innovative programs, 
appealing for change, and creating a coalition to support and implement changes (p. 66).

Leaders typically employed all three types of behaviors; however, appropriately applying the different types of behaviors to varying situations was fundamental to enhancing leader performance (Hoy \& Miskel, 2005).

Situational theories of leadership. Situational or contingency theories of leadership grew in prominence from the 1960s until the 1980s. The paradigm of leadership had shifted from a focus on specific traits and behaviors of the leader to the belief that the effectiveness of leader behavior was either enhanced or diminished by the aspects of the situation or environment (Yukl, 2006). In previous research, the behavior of the leader was an independent variable; from the perspective of the situational theorist, the behavior of the leader was a dependent variable (Yukl, 1982). The following section briefly summarizes common situational theories, in addition to addressing the perceived weaknesses of each theory.

Fiedler's contingency model. One of the earliest situational theories was Fiedler's (1967) least preferred coworker (LPC) theory. The theory posited that the leader's LPC score reflected the motive hierarchy of the individual, whether the leader was more oriented towards task accomplishment or more oriented toward interpersonal relationships. The LPC score was calculated by having the leader remember an individual, with whom the leader could work least well, and rate the individual on a set of bipolar adjective scales (Yukl, 2006). The LPC score was the sum of the ratings; a leader who was generally critical in rating the least preferred coworker would receive a low LPC score whereas a leader who was lenient in the rating would receive a high LPC score (Yukl, 2006).

In this model, the relationship between the leader's LPC score and the leader's effectiveness was dependent upon the favorability of the situation for the leader. Favorability 
was defined as the extent to which the situation gives the leader control over subordinates. Favorability was measured in terms of three situational variables: leader-member relations, position power, and task structure. Leader-Member Relations was the extent to which relations between the leader and their subordinates were friendly and cooperative, and the leader had the support and loyalty of subordinates. Position Power was defined as the extent to which the leader had authority to evaluate subordinate performance and administer rewards and punishments. Task Structure was the extent to which there was a detailed description of the finished product or service, standard operating procedures to accomplish the task, and objective indicators of how well the task is being performed (Fiedler, 1967; Yukl, 1982).

According to Fiedler (1967), if the task was highly structured, the leader had significant position power, and leader-member relations were good, a situation was labeled most favorable. In order of importance for situational favorability, Fiedler (1967) found that leader-member relations were most important, then task structure, and position power was least important.

The theory proposed that a leader with a low LPC score would be more effective than a leader with a high LPC score when the situation was either very favorable or very unfavorable. The inverse was proposed to be true when a leader with a high LPC score would potentially be more effective than one with a low LPC score; the situations that were identified as moderately favorable were the ones in which a low LPC score would be a predictor of effectiveness.

A criticism of this theory has been that the results of the research did not provide a satisfactory explanation of the correlation between the LPC score and the leader's effectiveness. It was not clear why a leader with a high LPC score would be more effective in some situations, and why a low LPC score would be equally effective in others (Miller, 2007; Yukl, 2006). 
Hersey and Blanchard's situational leadership theory. The theory by Hersey and Blanchard (1969) suggested that a leader must modify their behavior in response to the situation as defined by the maturity level of the follower. The theoretical construct for the behavior of the leader had been borrowed from the identified leadership behaviors from the Ohio State University studies: initiating structure and consideration.

The task behavior of the leader corresponded to initiating structure. Hersey and Blanchard (1969) defined task behavior as "the extent to which leaders are likely to organize and define the roles of members of their group, to explain what activities each is to do and when, where, and how tasks are to be accomplished; characterized by endeavoring to establish welldefined patterns of organization, channels of communication, and ways of getting jobs accomplished" (p. 107).

In summary, the behaviors of the leader, whether they were relationship-oriented or taskoriented, were applied in response to the maturity level of the follower. If a follower's maturity level was assessed as being low, the leader would exercise more task-oriented behaviors. As the maturity level of the follower increased, so did the relationship-oriented behaviors of the leader, until the follower was able to perform with greater autonomy.

Several limitations have been identified with this theory (Yukl, 1982, 2006). The initial weakness was there was not much research to support the theory. Hersey and Blanchard (1969) did not provide a coherent, explicit rationale for the hypothesized relationship between the leader and the follower. The focus on only two broad categories of leader behavior overlooked the distinctions among the different aspects of the behavior. Finally, maturity was very broadly defined. 
In spite of the identified weaknesses of the theory, a contribution to the body of work on situational leadership was made. The Hersey and Blanchard (1969) theory highlighted the need for the leader to be flexible and able to adapt their approach in response to the follower's need and to establish a proactive, developmental view of the follower's abilities.

Path-Goal theory. The Path-Goal Theory of leadership states that there is a relationship between the behavior of the leader and both the motivation and satisfaction of the followers (Yukl, 1982). The theory was originally created by Evans $(1969,1970)$ but was later elaborated upon by House (1971) and by Evans (1974) who included situational variables. According to House (1971), "the motivational function of the leader consists of increasing personal payoffs to subordinates for work-goal attainment, and making the path to these payoffs easier to travel by clarifying it, reducing roadblocks and pitfalls, and increasing the opportunities for personal satisfaction in route" (p. 324). It was also posited by House (1971) that the behavior of the leader had an impact on the follower's satisfaction with the job and also with the leader.

The other variable in the formula of follower motivation and satisfaction with the job and satisfaction with the leader was the situation (Yukl, 1982, 2006). The characteristics of the followers and the characteristics of the environment influenced the potential for increased motivation and also informed the leader in the way in which to improve motivation.

According to House (1971) situational variables also influenced the follower's preference for a particular pattern of leadership behavior. The four categories of leader behavior in the Path-Goal Theory were supportive leadership, directive leadership, participative leadership, and achievement-oriented leadership. Supportive Leadership included behavior that incorporated giving consideration to the needs of subordinates, displaying concern for their welfare, and creating a friendly climate in the work unit. Directive Leadership was letting subordinates know 
what they are expected to do, giving specific guidance, asking subordinates to follow rules and procedures, scheduling and coordinating the work. Participative Leadership consisted of consulting with subordinates and taking their opinions and suggestions into account when making decisions. Achievement-Oriented Leadership consisted of setting challenging goals, seeking performance improvements, emphasizing excellence in performance, and showing confidence that subordinates will attain high standards (Yukl, 1982, 2006).

Similar to Hersey and Blanchard's (1969) Situational Leadership Theory, according to the Path-Goal Theory, the type of leader behavior employed should have been selected based on the situation. For example, in an environment where there was ambiguity about the roles of the follower, directive leadership, which clarified each follower's role, had the potential to increase motivation by communicating how the effort of the follower would lead to superior performance. In relation to satisfaction with the job, the behavior of the leader that addressed role ambiguity would give followers greater clarity.

The research conducted using the Path-Goal Theory yielded mixed results (Yuk1, 1982, 2006). Yukl $(1982,2006)$ suggested that some of the limitations of the theory were the result of methodological limitations. There were conceptual ambiguities and confusion attributed to the different versions of the theory. House (1996) also identified the lack of the boundary conditions being clearly identified contributing to mixed and inconclusive results from research on this theoretical construct. However, the Path-Goal Theory contributed to the body of knowledge about leadership by illuminating the motivational functions of leaders and by identifying potentially important situational moderator variables (Yukl, 1982).

Substitutes for leadership. Kerr and Jermier (1978) proposed a theory that suggested there were situations in which a leader was redundant and the importance of managerial 
leadership was decreased. In the model, "substitutes" made leader behavior unnecessary and redundant. Substitutes were any characteristics of the followers, task, or organization that ensured the followers clearly understood their roles, knew how to do the work, were highly motivated, and were satisfied with their job (Yukl, 1982). Neutralizers were any of the characteristics of the task or the organization that inhibited the leader from behaving in a particular way or that counteracted the effect of the leader's behavior (Yukl, 1982).

The context of the organization determined the degree to which substitutes or neutralizers were present (Yukl, 2006). For example, in an organization with very detailed and clearly written plans, rules, procedures, standards, regulations, and policies, the leader would not need to continually instruct followers on how to complete their jobs. In this example, the structure was a substitute for the leader. However, in the same situation, if the structure was so inflexible that the leader was not permitted to make any adjustments or modifications, then the situation was a neutralizer of the behavior of the leader.

Yukl (2006) identified the lack of research as one of the critiques of this theory. However, the contribution to the body of research on situational leadership was that the theory addressed the substitutes for and neutralizers of leadership and their impact on the follower.

The work done by Osborn and Hunt (1975) mirrored the findings by Kerr and Jermier (1978) by addressing those factors over which the leader had limited or no control, e.g. the structure of the organization, the external environment, and the technology used. The major premise was that the organizational setting would both provide the leader with opportunities but will also constrain leader behavior.

Normative decision model. Vroom and Yetton (1973) expanded upon the Situational/Contingency Theory by positing that there were specific situations in which certain 
decision procedures, in addition to leadership behaviors, would be most effective. In 1988, Vroom and Jago (as cited in Yukl, 2006) made a revision to the model by expanding the list of variables and decision rules. According to Yukl (2006), "The decision procedures used by a leader affects the quality of a decision and decision acceptance by the people who are expected to implement the decision" (p. 89).

Tannenbaum and Schmidt (1958) stated "the leader's choice of decision procedures reflects forces in the leader, forces in the subordinates, and forces in the situation" (p. 98). Maier (1963) noted that the leader would be wise to take into consideration both the quality requirements of a decision and the likelihood that subordinates would accept such decision prior to selecting a decision procedure. Vroom and Yetton (1973) advanced the decision-making approaches by identifying which decision procedures and processes would be most effective in specific situations. In 1988, Vroom and Jago revised the initial model to include additional variables and decision rules. However, the different aspects of the situation also were a determining variable on the effect of the decision procedures.

Vroom and Yetton (1973) identified decision-making procedures that involved multiple subordinate roles:

A1 (Autocratic Decision). The leader solved the problem or made the decision using information available to them at the time.

A2 (Autocratic Decision Including Subordinates). The leader obtained the requisite information from the subordinates, and then made the decision himself or herself. The leader may or may not have informed the subordinates what the problem was while collecting the information from them. The role that was played by the subordinates in making the decision was 
one of providing necessary information to the leader, rather than generating or evaluating alternative solutions.

C1 (Consultation Decision). The leader shared the problem with the relevant subordinates individually, gathering their ideas and suggestions, without bringing them together as a group. The leader made the decision, which may or may not have reflected the subordinate's influence. C2 (Consultation Decision Including Subordinates). The leader shared the problem with the subordinates as a group, obtaining their collective ideas and suggestions. Then the leader made a decision, which may or may not reflect the subordinates' influence.

GII (Group Decision Including Subordinates). The leader shared the problem with the subordinates as a group. Together, alternatives were generated and evaluated and an attempt was made to reach consensus on a decision. The leader's role was much like that of a chairperson. The leader did not try to influence the group to adopt a preferred solution; rather the leader would accept and subsequently implement any solution that had the support of the entire group (Yukl, 2006, p. 89).

The effectiveness of a decision procedure depends on several aspects of the decision situation: (1) the amount of relevant information possessed by the leader and subordinates, (2) the likelihood that subordinates will accept an autocratic decision; (3) the likelihood that subordinates will cooperate if allowed to participate; (4) the amount of disagreement among subordinates with respect to their preferred alternatives; and (5) the extent to which the decision problem is unstructured and requires creative problem solving. (Yukl, 2006, p. 90) Decision acceptance was defined as the degree of commitment to implement a decision effectively (Yukl, 2006). The factors that influenced a subordinate's acceptance of a decision 
were similar to the factors in the Power Influence Model; how the subordinate perceived the situation influenced the acceptance of a decision made by the leader (Yukl, 2006).

Decision quality referred to "the objective aspects of the decision that affect group performance aside from any effects mediated by decision acceptance" (Yukl, 2006, p. 91). A decision may have been classified as a quality decision when the best solution was selected. The quality of a decision was only influenced by subordinate participation when the distribution of relevant information and problem solving was distributed between the leader and the subordinates (Yukl, 2006). Another factor that also had an impact on the quality of the decision that was linked to subordinate participation was the compatibility of the leader's objectives with the subordinates' objectives (Yukl, 2006).

Yukl (2006) identified several conceptual weaknesses with the Normative Decision Model. In this theory, decisions were characterized as single, discrete episodes that occurred at one specific moment in time. However, the reality is that important decisions are not made in that manner (Miner, 2005; Yukl, 2006). The leaders in the model were assumed to possess the requisite skills to effectively use each of the decision procedures (Yukl, 2006). The theory did not account for the leader's ability in utilizing the decision procedures and that ability level may also have been a variable when selecting which procedure to use for maximum effectiveness.

Charismatic leadership model. House (1977) is identified as one of the earliest researchers to address charisma as a trait of leaders, even though Weber (1947) identified charismatic authority as one of the three types of authority. House (1977) posited that charismatic leadership could indeed be defined in terms of testable propositions.

Charismatic leaders were likely to have a significant amount of self-confidence, a strong conviction in their own beliefs and ideals, and a high need to influence people (Yuk1 1982, 
2006). The self-confidence and the strong convictions of the leader increased the likelihood that the followers would place their trust in the leader's judgment (Yukl, 1982).

Charismatic leaders tended to behave in a manner that created the impression of competence and successfulness among the followers. Charismatic leaders were more likely to espouse and identify ideological goals for followers. The work and purpose of the group was grounded in common values, ideals, and aspirations. Charismatic leaders portrayed an appealing and inspiring vision of what the future held, with high expectations for follower performance. Charismatic leaders used role-modeling as a vehicle to influence followers' behavior by setting an example for followers to emulate. The charismatic leader's behavior tended to inspire motivation among followers for goal accomplishment. The authority of the charismatic leader primarily emanated from “the leader's overwhelming personal appearance, and typically a common value orientation. . within the group to produce an intense normative commitment to and identification with the person" (Hoy \& Miskel, 2005, p. 204).

One of the identified weaknesses of the Charismatic Leadership Theory was the overidentification with the leader (Yukl, 2006). The theory is one that is primarily leader-centered. Also, a weakness in the theory was the absence of the details of how the various elements of the influence process interacted (Yukl, 2006). Shamir, House and Arthur (1993), identified specific conditions under which charismatic leadership could potentially be effective: the organizational task is closely related to the dominant social values expressed by the followers, the organizational conditions do not favor leadership based on the use of extrinsic rewards and punishments, the organizational conditions require non-routine and unusually high performance. If there were conditions that could potentially enhance the effectiveness of a charismatic leadership style, conversely there would be conditions that could potentially limit the charismatic 
leader's effectiveness. Additionally, the subject of follower motivation was not the only variable linked to the effectiveness of the organization. Information about a leader's management in the other components: financial, structural, political were not addressed in the theoretical framework (Yukl, 2006).

Transformational leadership model. The early literature on leadership conflates charismatic leadership with transformation leadership. Some theorists treated transformational and charismatic leadership as the same, while others treated them differently (Miller, 2007; Yukl, 2006).

The initial theory of Transformational Leadership is attributed to Burns (1978). Burns (1978) posited that transformational leaders were able to inspire their followers to perform at higher levels than they would without a transformational leader. However, it was Bass (1985) (as cited in Curphy, 1992, p. 177) who was able to provide empirical evidence in support of this theory as an effective leadership practice.

Bass (1985) (as cited in Curphy, 1992), in his conceptualized description of transformational leadership, identified charisma as being the most important of the three subcomponents of charisma, individualized consideration, and intellectual simulation. In addition to possessing charisma, transformational leaders also showed individual consideration toward subordinates by possessing high levels of insight about subordinates, treating them as individuals, and by maintaining a mentoring or developmental attitude rather than fostering blind obedience. In essence, transformational leaders motivated followers, earned their respect, and lead them to better performance and expenditure of more effort (Clark \& Clark, 1992). The transformational leader engendered feelings of trust, admiration, loyalty, and respect for the leader (Yukl, 2006). 
The Transformational Leadership Model was an attempt to exemplify leadership in terms of the way the leader transforms and motivates followers (Yukl, 2006). The way this transformation and motivation occurred, according to Bass (1996), was by (1) making the follower more aware of the importance of task outcomes, (2) encouraging the followers to move beyond individual self-interests for the well-being of the organization or team, and (3) by activating their higher-order needs.

One of the weaknesses of this conceptual model is the leader-centeredness without a focus on the reciprocal influence processes, shared leadership, and mutual influence among the followers (Yukl, 2006). The theory also does not address the task-oriented functions of leaders that are important to the effective performance of the team (Yukl, 2006).

Multiple-Linkage model. Yukl originally conceptualized the Multiple-Linkage Model in 1981 (as cited in Yukl, 2006) from earlier theories of leadership and group effectiveness. The four types of variables identified in this model were: managerial behaviors, intervening variables, criterion variables, and situational variables. Yukl (1981), as cited in Yukl, 2006 posited that a leader's short-term effectiveness depended on their ability to correct any identified deficiencies in motivation; clarity of roles and responsibilities; organization of the work; group cohesiveness and teamwork of the subordinates; resources and support services; and external coordination. The interplay of the situational variables may have been identified as those factors that constrained or neutralized a leader's behavior; the factors that directly influenced the intervening variables; and those factors that mediated the importance of the intervening variables (Yukl, 1982, 2006).

According to this theory, a leader would not be maximally effective if they: (1) failed to recognize a deficiency in the intervening variables, (2) failed to act on an identified deficiency, 
or (3) acted, but did so in an insufficient manner as to address the identified deficiency. The theory was not prescriptive in its discussion of managerial behaviors; there were a variety of actions a leader may have elected to exercise. Yukl (2006) stated, "The overall pattern of leadership behavior by the designated leaders and other group members is more important than any single action" (p. 234). The thrust of the Multiple-Linkage Model was on the short-term managerial behaviors of the leader in the context of the present situation; the theory suggested that the leader's pattern of performance may modify the situation over time, as to make the situation a more favorable one (Yukl, 1982, 2006).

Yukl's (1982, 2006) Multiple-Linkage Model was an attempt to integrate the best practices from earlier models of leadership and group effectiveness into one theory. However, according to the founder of this model, "the complexity of the model makes it difficult to test in a single study" (Yukl, 2006, p. 235). Additionally, absent from the theory was a discussion of how the different leader behaviors interacted with each other and the collective effect those behaviors had on the intervening variables. Also, the lack of specificity regarding the effect of a leader's pattern of performance on the long-term effect of the situation was another conceptual weakness. The Multiple-Linkages Model remains in the stage of a conceptual framework, more so than a refined and operationalized theory (Yukl, 1982, 2006).

\section{Bolman and Deal's Four-Frame Leadership Orientation Model}

What Yukl $(1982,2006)$ stated had not been achieved, a valid and reliable way to evaluate the Multiple Linkage Model, was achieved with Bolman and Deal's Four-Frame Leadership Orientation Model (1984).

As has been briefly addressed in the proceeding discussion, each of the major theories on leadership was perceived to have either structural or conceptual limitations. The reoccurring 
pattern of weakness inherent in the major theories was that the theory would only account for one aspect of leadership at the exclusion of others. Bolman and Deal (1984) argued that even though each theory purported to be based on a scientific foundation, in reality, each was "also a theology that offer[ed] scripture and preach[ed] its own version of the gospel. .." (p. 3).

The Four-Frame Leadership Orientation Model consolidated the major schools of organizational thought into four perspectives - structural, human resource, political, and symbolic (Bolman \& Deal, 1984, 1991c, 2003). The theory was the distillation of the major schools of organizational theory and research in addition to knowledge from the social sciences e.g., sociology, psychology, political science, and anthropology (Bolman \& Deal 1984, 1991c, 2003). The purpose of the Four Frame Leadership Orientation Model was to provide leaders with useable knowledge (Bolman \& Deal, 1984, 1991c, 2003).

The structural frame, with origins in sociology and management science, "emphasizes goals, specialized roles, and formal relationships" (Bolman \& Deal, 2003, p. 14). The organizational structure is constructed to mesh with the organization's unique environment and specific technology. The focus of this frame is on the "architecture of the organization - the design of units and subunits, rules and roles, goal and policies - that shape and channel decisions and activities" (Bolman \& Deal, 2003, p. 18). The goal is to create a framework by which all the distinct parts of the organization operate in concert. Inherent to this frame is the belief that organizations are rational operations and that the correct structure and formal arrangement will minimize problems and maximize performance (Bolman \& Deal, 1984, 1991c, 2003).

Bolman and Deal assert the following structural frame assumptions:

- Organizations exist to achieve established goals and objectives. 
- Organizations increase efficiency and enhance performance through specialization and a clear division of labor.

- Appropriate forms of coordination and control ensure that diverse efforts of individuals and units mesh.

- Organizations work best when rationality prevails over personal preferences and extraneous pressures.

- Structures must be designed to fit an organization's circumstances (including its goals, technology, workforce, and environment).

- Problems and performance gaps arise from structural deficiencies and can be remedied through analysis and restructuring. (Bolman \& Deal, 2003, p. 45)

The structural frame has its leadership and management foundation in the work of Frederic Taylor (as cited in Shafritz, Ott, and Jang, 2005, p. 61) (2005), the father of time and motion studies, and in the work of Max Weber (as cited in Shafritz, Ott, and Jang, 2005, p. 73). The work of Weber was also instrumental in the research of bureaucratic authority and organization hierarchy. Additionally, Weber's research examined the elements of structures, analyzed why one organization selected a specific structure over another, and explored the impact of the structure on morale, productivity, and effectiveness (Bolman \& Deal, 2003).

The human resource frame addresses the interplay between the organization and the individuals affiliated with that organization (Bolman \& Deal, 1984, 1991c, 2003). The operating belief of the human resource frame and the key to organizational effectiveness is to tailor the organization to the people; the goal is to construct an organization that enables people to accomplish work tasks while feeling good about what they're doing (Bolman \& Deal, 1984, 1991c, 2003). 
Bolman and Deal $(1984,1991 \mathrm{c}, 2003)$ stated that everyone has needs, and that there was commonality among those needs. People behave in a manner to satisfy their own needs and become dissatisfied when the pursuit of satisfying those needs is thwarted (Bolman \& Deal, 1984, 1991c, 2003). All individuals are more inclined to learn new things that are affiliated with their needs, than to learn new things that are not. An individual's potential to flourish in an environment is related to the degree to which the individual is able to satisfy their needs, "and are likely to become psychologically undernourished in situations in which major needs are difficult or impossible to satisfy" (Bolman \& Deal, 1984, p. 69).

Bolman and Deal assert the following human resource frame assumptions:

- Organizations exist to serve human needs rather than the reverse.

- People and organizations need each other. Organizations need ideas, energy, and talent; people need careers, salaries, and opportunities.

- When the fit between the individual and the system is poor, one or both suffer. Individuals are exploited or exploit the organization - or both become victims.

- A good fit benefits both. Individuals find meaningful and satisfying work, and organizations get the talent and energy they need to succeed. (Bolman \& Deal, 2003, p. 115)

The human resource frame is grounded in the work of Maslow (as cited in Shafritz, Ott, and Jang, 2005, p. 167), and his Hierarchy of Needs. Additionally, the work of McGregor (as cited in Shafritz, Ott, and Jang, 2005, p. 179), Theory X and Theory Y is central to the theoretical underpinnings of the human resource frame. The conflict between the human personality and the traditional structure and management of organizations researched by Argysis $(1957,1964)$ also is reflected in the assumptions of the human resource frame. 
The organizational landscape from the political frame is one where the resources are scarce and power and influence constantly influence the allocation of those resources (Bolman \& Deal, 1984, 1991c, 2003). Conflict is to be assumed, rather than avoided because of the differences in needs, perspectives, and life-styles among the individuals within the organization (Bolman \& Deal, 1984, 1991c, 2003). From the political frame, organizations are seen as coalitions of individuals and interest groups. Each group has different objectives and different resources, and attempts to use those resources and relationships to influence the goals and decision making of the system (Bolman \& Deal, 1984, 1991c, 2003).

Bolman and Deal (2003) assert the following political frame assumptions:

- Organizations are coalitions of diverse individuals and interest groups.

- There are enduring differences among coalition members in values, beliefs, information, interests, and perceptions of reality.

- Most important decisions involve allocating scarce resources - who gets what.

- Scarce resources and enduring differences make conflict central to organizational dynamics and underline power as the most important asset.

- Goals and decisions emerge from bargaining, negotiation, and jockeying for position among competing stakeholders. (Bolman \& Deal, 2003, p. 186)

The symbolic frame views the organization as theater. While the other three frames are grounded in the assumption that organizations are rational, the symbolic frame does not (Bolman \& Deal, 1984, 1991c, 2003). The adhesive of the organization is its shared values and culture, rather than goals and policies (Bolman \& Deal, 1984, 1991c, 2003). According to the perspective from the symbolic frame, "organizations are propelled more by ritual, ceremonies, 
stories, heroes, and myths than by rules, policies, and managerial authority" (Bolman \& Deal, 1984, p. 7; 2003, p. 15).

The core assumptions for the symbolic frame are:

- What is most important is not what happens but what it means.

- Activity and meaning are loosely coupled; events have multiple meanings because people interpret experience differently.

- In the face of widespread uncertainty and ambiguity, people create symbols to resolve confusion, increase predictability, find direction, and anchor hope and faith.

- Many events and processes are more important for what is expressed than what is produced. They form a cultural tapestry of secular myths, heroes and heroines, rituals, ceremonies, and stories that help people find purpose and passion in their personal and work lives.

- Culture is the glue that holds an organization together and unites people around shared values and beliefs. (Bolman \& Deal, 2003, p. 242)

\section{Research on the Four-Frame Model by Bolman and Deal}

Bolman and Deal (1990) created an assessment instrument to measure a leader's use of the four frames in relation to their leadership practices and style. The authors reported that the test for internal reliability on the instrument yielded results between .91 and .93 on Cronbach's alpha for the four-frame measures (1991b).

Bolman and Deal conducted two investigations with the intent to operationalize the FourFrame concept and to test the basic postulates of the theory (1991a, 1991b). Included in the sample population were international corporate managers, higher education administrators, 
principals, central office administrators, and school officials from the Republic of Singapore (Bolman \& Deal, 1991a, 1991b).

The results of the qualitative study suggested that the majority of individuals utilized only one or two frames, and very few utilized all four frames (Bolman \& Deal, 1991a). In the results, the structural frame appeared most frequently, while the symbolic appeared least often (Bolman \& Deal, 1991a). The study yielded wide variety among the use of the human resource and political frame.

The results from the quantitative study suggested that the respondents identified each of the items for a particular frame as linked to one another, but distinct from the items used to address the other frames (Bolman \& Deal, 1991a). The analysis of the results indicated a strong relationship between an individual's frame orientation and their effectiveness as determined by colleagues. The data suggested that all four frames contribute to effectiveness (Bolman \& Deal, 1991a).

A study conducted by Bolman and Deal (1991b) mirrored the results of the 1991a study, by suggesting that the use of the frames was significantly related to leader effectiveness as determined by colleagues. The use of the structural frame was a better predictor of managerial effectiveness rather than leadership effectiveness (Bolman \& Deal, 1991b). The use of the symbolic frame was a better predictor of leadership effectiveness, rather than managerial effectiveness (Bolman \& Deal, 1991b). The study from Bolman and Deal (1991b) yielded results that suggested that the use of the human resource frame and the political frame was significantly related to success of both managers and leaders.

The findings in Bolman and Deal's 1991b study paralleled the findings in the 1991a study related to gender and the use of the frames. The results from both studies did not support 
the stereotype that women managers and leaders would score higher on the human resource frame than their male counterparts. Bolman and Deal (1991b) posited, "men and women in comparable positions are actually more alike than they are different" (p. 527).

\section{Research Using Bolman and Deal's Four-Frame Model}

Research using Bolman and Deal's Four-Frame model may be found in the literature of a variety of professions. The common characteristic woven throughout is the intent to study the leadership frames used by the leaders in each of those settings. The following summaries of studies using Bolman and Deal's Four-Frame model are germane to higher education.

Borden (2000) researched the utilization of the leadership frames of campus administrators in the Florida state university and community college system. The study sought to identify the leadership orientation of the campus administrators and to determine if there was a relationship between leadership orientation and the demographic variables: size of campus, campus type, highest level of coursework offered, highest level degree program, number of years the administrator had been in current position, the administrator's current position title, the number of years as an administrator, the administrator's highest level of education, gender, and age. Sypawka (2008), in his study of the leadership orientations of the division deans in the North Carolina community college system, included the education level of the dean, prior noneducational experience, and number of years serving as dean as selected demographic variables. Russell (2000) included self-reported measures of work-related stress and job satisfaction as the variables to compliment the leadership orientations research.

Bordern (2000), Russell (2000), and Sypawka (2008) all found the human resource frame was the predominant frame used by the campus administrators in their studies. Borden (2000) identified the symbolic frame as the second most used frame and the political frame as the least 
used among the administrators. Additionally, approximately half of the administrators were multi-frame users. In contrast, Sypawka (2008) found the paired-framed leadership style was most utilized by the North Carolina deans. The study however, did not yield statistically significant findings between the dean's perceived orientation leadership frame and any of the demographic variables. Finally, the deans in Russell's (2000) study, who self-reported use of a multi-frame leadership orientation, also reported lower stress, higher job satisfaction, and lower role-conflict as compared with those deans who reported only a single-frame leadership orientation.

Studies have also been conducted in the K-12 arena using Bolman and Deal's FourFrame Model to measure principals’ leadership orientation. Messer (2002) studied the leadership orientations of elementary school principals in a 15 county region of Florida public schools. The study identified the leadership orientations of the principals and measured whether or not there was a relationship between the leadership orientation and the variables of school size, student socioeconomic status, parent volunteer hours, PTA membership, and principal experience. Fleming (2003) researched the leadership orientations of principals in Comprehensive School Reform Demonstration (CSRD) and non-Comprehensive School Reform Demonstration (non-CSRD) schools in a mid-Atlantic state. One of the variables identified in the study was the school's composite index, which provided a performance measurement during a three-year period. Poniatowski (2006) examined the relationship of principals' utilization of the four-frame model and student achievement, using the Florida Comprehensive Assessment Testing (FCAT).

Both Messer (2002) and Poniatowski (2006) found the human resource frame was the predominant frame used by the principals. While in Fleming (2003), the structural frame was the 
highest rated among the four frames. In Messer (2002), $60 \%$ of the principals who returned the survey used a multi-frame leadership orientation, which is comparable to the majority of principals in Poniatowski (2006) who were multi-frame users. Additionally, in Fleming (2003), the principal consistently rated their frame use higher than the rating attributed to them by their teachers and in Poniatowski (2006), the data did not indicate a relationship between the principal's frame usage and student achievement.

Oliff (2006) researched the perceived leadership style of middle school principals and the relationship of the leadership orientation to school members' feelings about belonging to the school. The results of the study suggested there was a positive relationship between the principal's use of the three frames (human resource, political, and symbolic) and a sense among the teachers that others cared about their individual well-being. However, the leadership style of the principal did not appear to have a strong correlation with the students' sense of belonging to the school.

\section{Studies of the Four-Frame Model Relative to this Study}

In the arena of public education, much research has been conducted on the individuals who occupy leadership positions at the classroom level - teachers, at the building level principals, and at the district or central office level - superintendents. However, there is little research on individuals who occupy the leadership positions at the state education agency levelchief state school officers. Because of this lack of research on the position of chief state school officer, comparative studies on which to base this research were not available.

Hansen and Morphet (1970) said that the position of chief state school officer "is potentially as significant as that of the president of a large institution of higher learning" (p. 59). The positions in public education that may be most conceptually aligned with the position of 
chief state school officer are the position of superintendent of a large district and college or university president. Although not extensive in number, there have been studies conducted whose findings may be generalizable to this study of the leadership styles of the chief state school officers. The following section presents studies on college presidents and local education agency superintendents for the purpose of comparison with the population of chief state school officers.

College presidents. Bensimon (1989) sought to empirically explore the extent to which college and university presidents incorporated single or multiple vantage points in their descriptions of good leadership. The vantage points or perspectives were an adaptation of the four-frame model. Of the 32 college and university presidents studied, 13 espoused a singleframe orientation, 11 espoused a paired-frame orientation, seven espoused three frames and only one espoused a four-frame orientation. The findings showed the theories of leadership identified by college and university presidents were more likely to encompass a single- or a paired-frame rather than a multi-frame orientation.

DeFrank-Cole (2003) studied the leadership orientation of West Virginia college and university presidents. The research was conducted to identify the self-perceived leadership orientation of the presidents and to determine if there was a relationship between leadership orientation and gender. The results of the study revealed that there were no statistically significant differences in the leadership frames usages between female and male presidents in West Virginia. However, the political frame was slightly more used by male presidents than female presidents, and female presidents rather than male presidents in West Virginia used the human resource frame slightly more often. 
McArdle (2008) studied the leadership orientations of college presidents and the administrative teams that reported to the president. The purpose of the study was to identify the usage of the leadership frames of the presidents and their administrative teams, to ascertain if gender or years of experience in the current position were factors in frame usage in both groups and to determine if there was a relationship between the leadership frame usage by the president and the leadership frame usage of the president's administrative team. The major findings of the study were: the human resource frame was most utilized by both the presidents and the administrative teams, and there was not a statistically significant difference among frame use based on gender and number of years of experience in the current position. One specific finding from the phenomenological analysis revealed that presidents who utilized the political frame as a central theme in the scenarios, tended to have administrators who also used the political frame as either a single-frame or one of a paired-frame. Additionally, presidents who used the symbolic frame as a central theme in the scenarios, tended to have administrators who used all four frames as central themes in scenario responses.

Monahan (2004) studied the leadership frame usage of presidents of Master's 1 or higher education institutions. The study included the entire population of presidents at Master's 1 institutions, of which a $51.4 \%$ response rate was obtained. The results concluded that the majority of the presidents $(43.7 \%)$ utilized a multi-frame orientation. The second most used leadership orientation was the paired-frame, with $22.4 \%$ of the presidents in this category. The usage of the single-frame leadership orientation represented $20.9 \%$ of the presidents, and $13 \%$ had a no-frame leadership orientation. The research also yielded statistically significant results in relation to frame utilization. The frames utilized by the presidents in descending order were 
human resource $(30.7 \%)$, structural $(22.5 \%)$, political $(22.5 \%)$, symbolic $(18.8 \%)$ and no-frame $(5.5 \%)$

Ogu (2006) studied the leadership styles of presidents from Dominican colleges. The data for this study were gathered from institutional policy on leadership in Dominican colleges, the Leadership Orientation (self) questionnaire, and unstructured interviews. The results from the study revealed that the Dominican college presidents (6) in the study utilized all four frames.

Runkle (2004) studied the perceived use of the four frames in three essential functions of female community college presidents in California. The three functions of the presidents that were examined were decision-making, communication, and evaluation. Also analyzed was how the presidents engaged in values reflection and if there was a relationship between this reflection and style of leadership. The findings revealed that the practice of values reflection positively influenced the ability of the female community college presidents to utilize each of the four frames. The human resource frame was also revealed to be the frame that was most utilized by the female community college presidents. The study additionally yielded results that indicated the importance of the political frame in communication at the higher education level.

Toy (2007) researched the self-perceived leadership styles utilized by 18 permanently appointed African American women presidents at four year historically black colleges and universities. The demographic information collected about the presidents in the study was then compared to the demographic information of all presidents of colleges and universities, all presidents of historically black colleges and universities, and to all women college presidents. The results of the leadership orientation survey indicated that there was a strong correlation between years of service as president and the number of frames utilized. 
Superintendents. Flak (1998) examined the personal and professional characteristics of female superintendents in a mid-Atlantic state. The study found that the women tended to use more than one frame in their approach to their work. Frick (1996) examined the leadership orientations of Southern California public school superintendents of districts of 30,000 or fewer students, and their attitudes about change in their individual school districts. The data revealed significant differences in superintendents' leadership orientations based on gender, years of experience as a superintendent, and their perceptions about change in their respective districts. The political and symbolic frames were most affected by the readiness to change variables.

Ward (2006) examined the leadership orientations of Indiana public school superintendents. The results indicated that over $57 \%$ of the superintendents identified the human resource frame as their dominant frame, and $55 \%$ of the responses identified that the human resource frame was their most preferred frame, while $93 \%$ identified the political frame as their least preferred. The independent variables of gender, years of experience as a superintendent, school district setting, and initial level of training provided no statistically significant differences in the leadership frames that superintendents identified as their dominant frame. The study also yielded results that indicated that during decision-making processes, all the superintendents in the study reframed an average rate of $73 \%$ of the time. Additionally, female superintendents reframed $7 \%$ more often than male superintendents.

Winans (1995) examined the use of the frames by superintendents and school board members in viewing school organizations. The study yielded no significant differences between the groups of school districts across time in the use of the 4 frames. However, there were significant and moderately high-to-high correlations between each frame and satisfaction. Results indicated that superintendents and school board members are more likely to increase 
their own and each other's satisfaction by using each of the four frames, especially the symbolic frame, as part of a school districts' operation.

\section{Summary}

This chapter began with a focus on the literature relative to the historical perspective of the role of the chief state school officer. A presentation of how that role has developed to encompass significant responsibility for the financial resources and the human resources of the state, in addition to the social justice responsibility for an effective and efficient education for the public school-aged children, was articulated. A historical perspective of educational governance models preceded a review of the current models of educational governance. A discussion of how the study of leadership from the early 1900s to the present has transitioned from a focus on the individual characteristics of effective leaders to identifying the leadership behaviors, in the context of the organizational structure, that have the greatest potential to motivate followers was presented. Finally, the Bolman and Deal Four-Frame Model and the supporting research were presented.

The review of literature related to leadership establishes the importance of leadership for the vitality of the organization, the well being of the employees, and for the maximum performance from the members of the organization. The study of leadership in state education agencies is not an exercise in evaluating the effective and efficient discharge of an office in an organization that manufactures a product. Rather, state education agencies are crucial organizations. They are the vehicles by which public education is managed and coordinated in each state. The chief state school officer has enormous responsibility not only for the members of the organization, but also for the vast constituencies of public education. Effective leadership is of utmost importance. Given the high-stakes nature of the position and the expansive scope of 
responsibilities, research about leadership effectiveness for the position would accelerate chief state school officers' learning. Unfortunately, there is very little literature about chief state school officers and their leadership styles and leadership practices. This study will contribute to the body of leadership research about an understudied population of educational leaders. 


\section{Chapter Three: Methods}

Chapter Three includes the methods used to describe the leadership styles of the chief state school officers and to determine whether a relationship existed between the leadership styles of the chief state school officers and the models of educational governance in their respective states. The study served to establish baseline data about the leadership styles of chief state school officers, heretofore, the leadership styles of this population of educators had not been previously been studied.

The study described the leadership styles of the chief state school officers through the lenses of several demographic variables: age, gender, ethnicity, highest degree earned, and years of experience as a chief state school officer, years of administrative experience, and total years of educational experience. These demographic variables were selected to make comparisons to previous research that contained similar demographic variables. The data about leadership styles were collected using the Bolman and Deal Leadership Frames Orientations (Self) Survey instrument (1990). This chapter includes the following sections: research design, population, instrumentation, data collection procedures, anonymity and confidentiality, data analysis and collection, and summary.

\section{Research Design}

This descriptive study utilized a self-reported, web-based survey instrument to answer each of the research questions. Descriptive studies, as defined by Gay, Mills and Airasian (2006), use questionnaire surveys, telephone surveys, interviews, or observations to identify specific attitudes, demographics, and practices. The study gathered baseline data about the leadership styles of chief state school officers. 
The research design involved collecting data to describe the leadership styles of the chief state school officers and to answer the following research questions:

Question 1. What are the leadership frames (structural, human resource, political, and symbolic) of the chief state school officers?

Question 2. What are the leadership styles (no-frame, single-frame, paired-frame, and multi-frame) of the chief state school officers?

Question 3. Are there differences between the leadership frames of chief state school officers and selected demographic variables?

Question 4. Are there differences between the leadership styles of chief state school officers and selected demographic variables?

Question 5. Do the leadership frames of the chief state school officers differ across the models of educational governance (Model One, Model Two, Model Three, and Model Four)?

Question 6. Do the leadership styles of the chief state school officers differ across the models of educational governance (Model One, Model Two, Model Three, and Model Four)?

\section{Research Population}

The 51 chief state school officers in the United States including, the chief state school officer for the District of Columbia were selected for the study. The chief state school officers of the Bureau of Indian Education, Department of Defense Education Activity, and the U.S. Territories of American Samoa, Guam, Northern Marina Islands, Puerto Rico, and the Virgin Islands were not included in the population because the educational governance structures are 
significantly different than the models currently used in the United States. The invitation to participate in the research study was sent to all 51chief state school officers.

\section{Instrumentation}

Bolman and Deal's Leadership Orientations (Self) Survey. Bolman and Deal created the theoretical framework for the four leadership frames (structural, human resource, political, and symbolic) during the late 1970s and early 1980s. The Leadership Orientation Survey instruments were created to describe an individual's leadership orientation relative to the use of the frames (Bolman \& Deal, 1990). The Leadership Orientation Survey has two versions, Self and Other. The Self survey is intended to be used by individuals to assess themselves, and the Other survey is designed for colleagues, superiors, and or subordinates (others) to assess the leadership orientation of the leader. The Leadership Orientation (Self) Survey was used in this study to collect data from the chief state school officers. Lee Bolman granted permission for the use of the Bolman and Deal Leadership Orientation (Self) Survey to be used and to be administered electronically (Appendix A).

The Leadership Orientation Survey (Bolman \& Deal, 1990) has three distinct sections. Section I of the Leadership Orientation (Self) was used in this study. The rationale for use of only Section I of the survey is that Sections II and III are primarily used for management development rather than for research (Bolman, 2010).

Section I contains 32 items, with eight assessment indicators for each of the four frames (structural, human resource, political, and symbolic). Each of the assessment items in the survey is presented in a consistent pattern. Structural indicators are asked in questions 1, 5, 9, 13, 17, 21, 25, and 29. Human resource indicators are asked in questions 2, 6, 10, 14, 18, 22, 26, and 30. Political frame indicators are asked in items 3, 7, 11, 15, 19, 23, 27, and 31. Symbolic frame 
indicators are asked in items 4, 8, 12, 16, 20, 24, 28, and 32. A five-point Likert scale was used to evaluate the degree to which the chief state school officer demonstrated the behavior identified in the indicator (1-never, 2-occasionally, 3-somethimes, 4-often, and 5-always). Each respondent was assigned a mean score for each of the frames based upon the answers to the items. A mean score of a 4.0 or greater for any one of the frames indicated an individual's use of that frame in a leadership capacity.

Respondents were then identified as possessing one of the four leadership styles (noframe, single-frame, paired-frame, and multi-frame) based upon the number frame means at or above a 4.0. A frequency count was used to describe the leadership styles of the respondents.

Validity and Reliability. The reliability of the Leadership Orientation Survey has been verified by previous research (Bolman \& Deal, 1991a, 1991b). The research of the Leadership Orientation Survey was based on the data from approximately 1,300 colleague ratings for a multi-sector sample of managers in business and education (Bolman, 1991a, 1991b). However, the research has found that the validity of self-ratings of leadership is generally low (Bolman, 2010). Bolman and Deal stated (1991b), "There is no perfect way to measure thinking. . Our survey instrument is constructed on the assumption that managers' behavior mirrors their internal cause maps or theories for action" (p. 14). The primary purpose of the study was to ascertain the chief state school officers' individual perception of their leadership styles, thus the low validity of the Leadership Orientation (Self) Survey did not negatively affect the results of this study.

A variety of statistical analyses have been conducted to test the reliability of the Leadership Orientation Survey instrument (Bolman \& Deal, 1991a, 1991b). The split-half correlation, which tests the internal consistency by dividing a test into two halves and correlating the scores on the two halves (Gay, Mills \& Airasian, 2006), was conducted. According to 
Bolman and Deal (1991a), the results for each of the four frames were as follows: structural $(\mathrm{r}=$ $.875)$; human resource $(\mathrm{r}=.876)$, political $(\mathrm{r}=.837)$; and symbolic $(\mathrm{r}=.882)$. The Spearman-

Brown coefficient, another test for reliability, yielded the following results: structural $(\mathrm{r}=.933)$; human resource $(r=.929)$, political $(r=.911)$; and symbolic $(r=.937)$. The Guttman (Rulon) coefficient exceeded 0.91 in all four frames. According to Bolman and Deal (1991b), the Cronbach's alpha, which measured inter-item reliability for each of the frame measures, was very high, ranging from .91 to .93 . Penix (2009) also confirmed the reliability of the Leadership Orientation Survey using the Cronbach's alpha with a range between .913 to .933 . The Leadership Orientation Survey, Self and Other, has been used in numerous studies and dissertations (Bensimon, 1989; Borden, 2000; DeFrank-Cole, 2003; Deluca, 2007; Englert, 2008; Flack, 1998; Fleming, 2003; Frick, 1996; McArdle, 2008; Messer, 2002; Monhan, 2008; Ogu, 2006; Oliff, 206; Penix, 2009; Poniatowski, 2006; Runkle, 2004; Russell, 2000; Sypawka, 2008; Toy, 2007; Ward, 2006; \& Winans, 1995).

\section{Anonymity and Confidentiality}

Institutional Review Board (IRB) recognition was obtained prior to the initiation of data collection (Appendix B). The Participant Letter (Appendix C) that was mailed to the chief state school officers explained the purpose of the research, the voluntary participation option, their right to not respond to all questions, and an explanation of the measures that were enacted to protect their anonymity and confidentiality. The articulated procedures were designed in accordance with the IRB guidelines.

\section{Data Collection Procedures}

All 51 chief state school officers in the United States including, the chief state school officer from the District of Columbia were mailed an introductory packet via U.S. Postal Service. 
The packet contained a Participant Letter and a note card from the West Virginia State Superintendent of Schools at the time, Dr. Steven L. Paine (Appendix D). Dr. Paine introduced the researcher as an employee of the state education agency in West Virginia and requested the participation of the chief state school officers in the research project. The Participant Letter explained how the chief state school officers were to access the Web site where the survey was located. The surveys were distributed electronically through the Zoomerang Online Survey Software (http://www.zoomerang.com). Each chief state school officer was assigned an individualized survey in order to match the survey response to the state model of governance.

The chief state school officers were asked to complete the survey between February 13, 2010 and March 19, 2010. At the end of two weeks in the survey process (February 26, 2010), a follow-up email (Appendix E) was sent to the participants who had not responded. A second follow-up email (Appendix F) was sent to individuals who had not responded during the week of March 8, 2010. The surveys were closed on March 19, 2010.

\section{Data Analysis}

Data collected from the surveys were analyzed to determine the following: (1) what were the leadership styles of the chief state school officers; (2) was there a difference in leadership styles among the chief state school officers based upon demographic variables (age, gender, ethnicity, highest degree earned, and years of experience as a chief state school officer, of administrative experience, and total years of educational experience); and (3) was there a difference in leadership styles among the chief state school officers based upon the models of educational governance in their respective states.

The Bolman and Deal Leadership Orientations (Self) Survey (1990) instrument and the demographic questionnaire were utilized to gather data for the analysis for this study. The 
Statistical Package for the Social Sciences (SPSS) software was used to analyze the data.

Descriptive data analysis was conducted on the demographic variables and the leadership styles.

Descriptive statistics were used to determine the mean score for each chief state school officer for each of the four frames. Further descriptive analyses were conducted to determine the standard deviations of the means, the frequency, and the percentage of frames utilized. A oneway ANOVA was also used to determine if there were differences in the frame mean scores of the chief state school officers and the demographic variables of age, gender, ethnicity, and highest degree earned and by models of educational governance. A Spearman Rho correlation analysis of the frame mean score and years of experience categories and an analysis of leadership style and years of experience categories were conducted. A Chi-Square analysis was used to determine if there were significant differences in the frequency distribution of the leadership styles of the chief state school officers and the selected demographic variables of age, gender, ethnicity, highest degree earned and model of educational governance. The following research questions and statistical computations yielded data for analysis.

Question 1. What are the leadership frames (structural, human resource, political, and symbolic) of the chief state school officers?

Descriptive statistics were used to calculate the mean and the standard deviation for each of the four frames (structural, human resource, political, and symbolic) to describe frame utilization by chief state school officers.

Question 2. What are the leadership styles (no-frame, single-frame, paired-frame, and multi-frame) of the chief state school officers?

Descriptive statistics were used to describe the leadership styles (no-frame, single-frame, paired-frame, and multi-frame) of the chief state school officers. The mean scores for each chief 
state school officer were used to determine the leadership style. The analysis included determining which of the four frames were utilized by verifying mean scores were at or above the 4.0 threshold, which indicated use of that particular frame. The frames that were determined to be used were summed to determine the leadership style, multi-frame - more than three frames used, paired-frame - two frames used, single-framed - one frame used, and no-frame, no mean score above 4.0 .

Question 3. Are there differences between the leadership frames of chief state school officers and selected demographic variables?

Null Hypothesis. There are no significant differences in the frame utilization of the chief state school officers by selected demographic variables.

Descriptive statistics were used to calculate the mean and the standard deviation for each of the four frames (structural, human resource, political, and symbolic) to determine frame utilization by chief state school officers. A one-way ANOVA was used to determine if there were significant differences in mean scores of frame utilization of the chief state school officers and select demographic variables (age, gender, ethnicity, and highest degree earned). A Spearman Rho correlation analysis of the mean score of frame utilization and years of experience was conducted to analyze whether a correlation existed between the mean scores and years of experience.

Question 4. Are there differences between the leadership styles of chief state school officers and selected demographic variables?

Null Hypothesis. There are no significant differences in the frequency distribution of leadership styles of the chief state school officers by selected demographic variables. 
Descriptive statistics were used to analyze the frequency distribution of leadership styles (no-frame, single-frame, paired-frame, and multi-frame) of the chief state school officers in relation to selected demographic variables (age, gender, ethnicity, and highest degree earned). A Chi-Square analysis was conducted to determine if there were statistical differences between the leadership styles among the chief state school officers and selected demographic variables (age, gender, ethnicity, and highest degree earned). A Spearman Rho correlation analysis of the leadership styles and years of experience categories was conducted to analyze whether a correlation existed between leadership style and years of experience.

Question 5. Do the leadership frames of the chief state school officers differ across the models of educational governance (Model One, Model Two, Model Three, and Model Four)?

Null Hypothesis. There are no significant differences in the frame utilization of the chief state school officers by model of educational governance.

Descriptive statistics were used to calculate the mean and the standard deviation for each of the four frames (structural, human resource, political, and symbolic) to determine frame utilization by model of educational governance. A One-Way ANOVA was used to determine if there were significant differences in mean scores of frame utilization of the chief state school officers and model of educational governance (Model One, Model Two, Model Three, and Model Four).

Question 6. Do the leadership styles of the chief state school officers differ across the models of educational governance (Model One, Model Two, Model Three, and Model Four)?

Null Hypothesis. There are no significant differences in the frequency distribution of leadership styles of the chief state school officers by model of educational governance. 
Descriptive statistics were used to analyze the frequency distribution of leadership styles (no-frame, single-frame, paired-frame, and multi-frame) of the chief state school officers in relation to model of educational governance. A Chi-Square analysis was conducted to determine if there were statistical differences between the leadership styles among the chief state school officers and model of governance.

\section{Summary}

Chapter Three addressed the methods used in this study to describe the leadership styles of the chief state school officers and to determine whether a relationship existed between the leadership frame utilization and leadership styles of the chief state school officers compared with selected demographic variable and the four different models of educational governance. This chapter delineated the research design, population, instrumentation, data collection procedures, and data analysis. This chapter also addressed the measures that were taken in order to ensure the anonymity and confidentiality of the participants in this study. 


\section{Chapter 4: Analysis of Results}

\section{Findings}

Chapter Four presents the results regarding the self-perceived leadership styles of the chief state school officers of the United States. This study examined whether there was a relationship between the leadership frames of the chief state school officers, selected demographic variables, and the models of educational governance, in addition to examining if a relationship existed between the leadership styles of the chief state school officers, selected demographic variables and models of educational governance. The analysis of the leadership styles of the chief state school officers was based on the framework of Bolman and Deal's (1984, 1991c, 2003) four-frame leadership model (structural, human resource, political, and symbolic). Data identifying the leadership styles were collected and analyzed in the following areas: frame utilization (structural, human resource, political, and symbolic); leadership style (no-frame, single-frame, paired-frame, and multi-frame); model of educational governance (Model One, Model Two, Model Three, and Model Four); and selected demographic variables.

The survey instrument used was the Leadership Frames Orientation (Self) by Bolman and Deal (1990). The validity of the survey instrument was established by previous research (Bolman \& Deal, 1991a, 1991b). The weak reliability was addressed by Bolman (2010), and did not negatively impact this study, as the intent was to collect the self-perceptions of the chief state school officers. The demographic variables were age (younger than 40 years of age, 40-49 years of age, 50-59 years, and 60 years or older), gender, ethnicity (White, non-Hispanic; Black or African American; Hispanic or Latino; Asian; American Indian or Alaska Native; Native Hawaiian or Pacific Islander; or Other), highest degree earned (Bachelor's Degree, Master's Degree, Doctoral Degree, or other Terminal Degree), years of experience as a chief state school 
officer, years of administrative experience (excluding current position), and total years of experience in an educational setting. The first section of the chapter outlines the demographic data of the chief state school officer respondents. The second section focuses on analysis of data for each of the six research questions. The last section summarizes the chapter and the findings of the study.

\section{Respondents}

There were 51 chief state school officers identified as the research population of this study, which corresponded to the entire population of chief state school officers in the United States. The target return rate was at least $80 \%$. The actual return rate was $62.75 \%$; however, only 30 usable responses were obtained. The analysis was based upon 30 responses $(\mathrm{N}=30$, 58.8\%). As discussed previously in Chapter Two, the distribution of the chief state school officers among the four models of educational governance was 14 states in Model One, 10 states in Model Two, 14 states in Model Three, and 13 states in Model Four.

Table 4 presents the survey responses by model of educational governance. Eight of the $14(57.1 \%)$ chief state school officers from Model One responded to the survey. Eight of the 10 $(80.0 \%)$ chief state school officers from Model Two responded to the survey. Six of the 14 (42.9\%) chief state school officers from Model Three responded to the survey. Eight of the 13 $(61.5 \%)$ chief state school officers from Model Four responded to the survey. The respondents $(\mathrm{N}=30)$ consisted of $26.7 \%$ from Model One, $26.7 \%$ from Model Two, $20.0 \%$ from Model Three, and $26.7 \%$ from Model Four.

The response rate among the models varied slightly; the highest response rate was from Model Two (80.0\%) and the lowest was from Model Three (42.9\%). The response rate from the chief state school officers in Model Two was slightly higher (7.1\%) than the total percentage 
of Model Two states. The response rate from Model Three chief state school officers was lower $(7.5 \%)$ than the total percentage of Model Three states. Therefore, in the number of responses, there was a higher representation from Model Two and a lower representation from Model Three.

Table 4

Response Rate by Model of Educational Governance

\begin{tabular}{lccccc}
\hline $\begin{array}{l}\text { Educational } \\
\text { Governance }\end{array}$ & $\begin{array}{c}\text { Number in } \\
\text { Population }\end{array}$ & $\begin{array}{c}\text { Total \% } \\
\text { Population }\end{array}$ & $\begin{array}{c}\text { Number of } \\
\text { Respondents }\end{array}$ & $\begin{array}{c}\text { Total \% } \\
\text { Response }\end{array}$ & $\begin{array}{c}\text { Response } \\
\text { Rate by } \\
\text { Model }\end{array}$ \\
\hline Model One & 14 & 27.5 & 8 & 26.7 & 57.1 \\
Model Two & 10 & 19.6 & 8 & 26.7 & 80.0 \\
Model Three & 14 & 27.5 & 6 & 20.0 & 42.9 \\
Model Four & 13 & 25.5 & 8 & 26.7 & 61.5 \\
Total & 51 & 100.0 & 30 & 100.0 & \\
\hline
\end{tabular}

Table 5 presents the demographic variables of the respondents. Among the 30 chief state school officers who responded to this survey, two $(6.7 \%)$ were younger than 40 years of age, six (20.0\%) were 40-49 years of age, 14 (46.7\%) were 50-59 years of age, and eight $(26.7 \%)$ were 60 years of age or older. In this study, $19(63.3 \%)$ of the survey responses were from male chief state school officers, while 11 (36.7\%) were from female chief state school officers. The ethnicity of the respondents was reported as $27(90.0 \%)$ White, non-Hispanic, one (3.3\%) Black, African American, one (3.3\%) Hispanic, and one (3.3\%) Asian. Of the chief state school officers who responded, 10 (33.3\%) identified a Master's Degree as the highest 
degree earned, $18(60.0 \%)$ identified a Doctoral Degree as the highest degree earned, while two (6.7\%) chief state school officers identified a Juris Doctor degree as their highest degree earned. At the time the research for this study was collected (2010), approximately 63\% (32) of the population of chief state school officers was male and $37 \%$ (19) was female. The respondents accurately represent the population in terms of gender. However, there were no reliable data about the other demographic variables.

Table 5

Demographic Variables

\begin{tabular}{lcc}
\hline Demographic Variables & Number $(\mathrm{N}=30)$ & \% of Respondents \\
\hline Age & & \\
Under 40 years & 2 & 6.7 \\
$40-49$ & 6 & 20.0 \\
$50-59$ & 14 & 46.7 \\
Above 60 & 8 & 26.7 \\
& & \\
Gender & 19 & 63.3 \\
Male & 11 & 36.7 \\
Female & & \\
Ethnicity & & 90.0 \\
White, non-Hispanic & 27 & 3.3 \\
Black & 1 & 3.3 \\
Hispanic & 1 & 3.3 \\
Asian & 1 & \\
Highest Degree Earned & & 33.3 \\
Master's & 10 & 60.0 \\
Doctorate & 18 & 6.7 \\
Other & 2 & \\
\hline
\end{tabular}

Table 6 presents the years of experience of the respondents. The average number of years as a chief state school officer was 3.82 years, with a range of 2 months to 17 years of 
experience. The respondents had an average of 21.8 years (range of 6 to 37 years) of administrative experience, excluding the years in their current position as chief state school officer. In total, the chief state school officers had an average of 31.4 (range of 15 to 50 years) years of experience in an educational setting.

The distribution of the data identified an outlier who had 17 years of experience as a chief state school officer. The mean years of experience, excluding the outlier, as chief state school officer was 3.36 years, with a standard deviation of 2.40 (range of 2 months to 7 years), which may be a more accurate representation of respondents. The next highest number of years as experience as a chief state school officer was seven years. The mean years of experience, including the outlier, as chief state school officer was 3.82 years, with a standard deviation of 3.43. The number of chief state school officers with less than one year of experience was four $(13.3 \%)$. The majority, $43.3 \%$ or 13 , chief state school officers had between one to four years of experience. The number of chief state school officers with 4.1 to 7.0 years of experience was $12(40.0 \%)$. The years of experience in other administrative positions and the total number years in an educational setting were more evenly distributed; no outlier was identified in the data.

Table 6 Years of Experience of Chief State School Officers

\begin{tabular}{lccc}
\hline \multicolumn{1}{c}{ Years of Experience } & Mean & $\begin{array}{c}\text { Standard } \\
\text { Deviation }\end{array}$ & Range \\
\hline Current position & 3.82 & 3.43 & $.17-17 \mathrm{yrs}$ \\
Other administrative positions & 21.8 & 8.08 & $6-37 \mathrm{yrs}$ \\
Total in educational setting & 31.4 & 8.19 & $15-50 \mathrm{yrs}$ \\
\hline
\end{tabular}




\section{Analysis of Data}

This section presents major findings of the data analysis as they relate to each of the research questions in this study. The .05 level was used for all statistical analyses.

Question 1. What are the leadership frames (structural, human resource, political, and symbolic) of the chief state school officers?

Table 7 presents the means and standard deviations of the respondents for the four leadership frames (structural, human resource, political, and symbolic). The human resource and symbolic frames had the highest mean $(M=4.11, S D=.47, \mathrm{SD}=.60)$, followed by the political frame $(M=4.08, S D=.46)$. The structural frame had the lowest mean $(M=3.99, S D=$ $.59)$.

Table 7

Frame Means of Chief State School Officers

\begin{tabular}{lcc}
\hline \multicolumn{1}{c}{ Leadership Frame } & Mean & $\begin{array}{c}\text { Standard } \\
\text { Deviation }\end{array}$ \\
\hline Structural & 3.99 & .59 \\
Human Resource & 4.11 & .47 \\
Political & 4.08 & .46 \\
Symbolic & 4.11 & .60 \\
\hline
\end{tabular}

A mean score of 4.0 or better for any one of the four leadership frames indicated utilization of the frame. Based on the mean scores for each frame in Table 7, chief state school officers were more likely to use the human resource, political, and symbolic frames and less 
likely to use the structural frame. The structural mean failed to reach the 4.0 mean necessary to indicate usage of that frame in the total group of respondents.

The 30 respondents in this study utilized a total of 75 frames. Table 8 presents the frequency distribution of frame utilized by the chief state school officers. The human resource frame was most frequently employed $(26.6 \%)$ and the no-frame $(5.0 \%)$ was the least utilized. Table 8

Frame Utilization Alone or in Concert

\begin{tabular}{lcc}
\hline & $\mathrm{N}$ & $\%$ \\
\hline No-frame & 4 & 5.0 \\
Structural & 17 & 21.6 \\
Human Resource & 21 & 26.6 \\
Political & 18 & 22.8 \\
Symbolic & 19 & 24.0 \\
Total & 79 & 100.0 \\
\hline
\end{tabular}

Question 2. What are the leadership styles (no-frame, single-frame, paired-frame, and multi-frame) of the chief state school officers?

The leadership style was determined by the use of leadership frames with an average of 4.0 or greater on the survey for each of the frames. The no-frame leadership style reflects no leadership frame score above a 4.0. The single-frame leadership style reflects a score of a 4.0 in any one of the frames. A paired-frame leadership style reflects a score of 4.0 or greater in any two of the leadership frames. A multi-frame leadership styles reflects a score of 4.0 or greater 
in three or more of the frames. Table 9 summarizes the leadership styles of the chief state school officers by frame pattern.

Table 9

Leadership Style and Frame Pattern

\begin{tabular}{|c|c|c|c|}
\hline Leadership Style/Frame Pattern & Frequency & $\begin{array}{c}\% \\
\text { Leadership } \\
\text { Style }\end{array}$ & $\begin{array}{c}\% \\
\text { Respondents }\end{array}$ \\
\hline No-frame & 4 & & 13.3 \\
\hline Single-frame & 3 & & 10.0 \\
\hline Structural & 0 & 0 & \\
\hline Human Resource & 2 & 66.7 & \\
\hline Political & 1 & 33.3 & \\
\hline Symbolic & 0 & 0 & \\
\hline Paired-frame & 7 & & 23.3 \\
\hline Structural/Human Resource & 1 & 14.3 & \\
\hline Structural/Symbolic & 1 & 14.3 & \\
\hline Human Resource/Political & 1 & 14.3 & \\
\hline Human Resource/Symbolic & 2 & 28.6 & \\
\hline Political/Symbolic & 2 & 28.6 & \\
\hline Multi-frame & 16 & & 53.3 \\
\hline $\begin{array}{l}\text { Structural/Human } \\
\text { Resource/Political/Symbolic }\end{array}$ & 10 & 62.5 & \\
\hline Structural/Human Resource/Political & 2 & 12.5 & \\
\hline Structural/Political/Symbolic & 1 & 6.3 & \\
\hline Structural/Human Resource/Symbolic & 2 & 12.5 & \\
\hline Human Resource/Political/Symbolic & 1 & 6.3 & \\
\hline Total & 30 & & 100.0 \\
\hline
\end{tabular}

The majority of the chief state school officers $16(53.3 \%)$ were identified with a multiframe leadership style. Of those, 10 (33.3\% of respondents) utilized all four frames, which corresponded to $62.5 \%$ of the respondents who were identified as possessing a multi-frame leadership style. The remaining $37.5 \%$ of the multi-frame leadership style category employed a 
combination of three leadership frames. The second most utilized leadership style was the paired-frame with seven (23.3\%) respondents. In this group, the most common frame was the symbolic frame, which was present in five of the seven responses. The third most utilized leadership style was the no-frame leadership style with four (13.3\%) of the respondents having been identified without a mean score of 4.0 in any of the leadership frames. The least used leadership style was the single-framed leadership style. Three (10.0\%) of the respondents were identified with this leadership style. In this group, two respondents used the human resource frame, and one respondent used the political frame.

Question 3. Are there differences between the leadership frames (structural, human resource, political, and symbolic) of chief state school officers and selected demographic variables (age, gender, ethnicity, highest degree earned, and years of experiences as a chief state school officer, in administration, and total number in education)?

Age. The results of a one-way analysis of variance did not show a statistically significant difference between the age categories and the chief state school officers' utilization of the four leadership frames.

The trend of the data indicated that the age category $40-49$ failed to reach the 4.0 mean necessary to indicate the usage of any leadership frame. The other age categories reached the 4.0 threshold to indicate frame utilization of the four leadership frames. The mean score for the political frame was the highest in the younger than 40 years of age category, $\mathrm{M}=4.31$.

Gender. The results of a one-way analysis of variance did not show a statistically significant difference between gender and the chief state school officers' utilization of the four leadership frames. Therefore, the null hypothesis was not rejected. 
The highest mean for the males was the political frame $(M=4.01, S D=.37)$. The highest mean for females was the human resource frame $(M=4.24, S D=.39)$. The male chief state school officers did not reach the 4.0 mean to indicate the usage of the structural frame, whereas females utilized all frames.

Ethnicity. The analysis of the demographic variable of ethnicity and mean scores of the leadership frames did not yield a statistically significant difference. As displayed in Table 5, 27 $(90.0 \%)$ respondents identified White, non-Hispanic as their ethnicity, one (3.3\%) respondent indicated Black, African American, one (3.3\%) respondent selected Hispanic, and one (3.3\%) selected Asian.

Highest degree earned. Table 10 presents the results of the one-way analysis of variance on the human resource frame means and highest degree earned. There were significant differences between the mean scores of the chief state school officers with a master's degree and those with a juris doctor degree at the .05 level. Additionally, the differences between the chief state school officers with a doctorate degree and juris doctor were significant at the .009 level. The doctorally prepared chief state school officers had the highest mean in the human resource frame $(M=4.24, S D=.38)$, followed by the chief state school officers holding a master's degree $(M=4.06, S D=.46)$, while the mean score for the juris doctorally trained chief state school officers was 3.25 with a .35 standard deviation. Additionally, only the doctorally trained chief state school officers had mean scores above the 4.0 threshold in all four frames. The Other category, which consisted of two chief state school officers, indicated usage of only the political frame with a mean of 4.13 and a standard deviation of .71, although the category was too small from which to make generalizations. There were no other significant differences between the mean scores for the other frames. 
Table 10

One-Way Analysis of Variance of Human Resource Frame Mean and Highest Degree Earned

\begin{tabular}{lccccc}
\hline Source & $d f$ & $S S$ & $M S$ & $F$ & $P$ \\
\hline $\begin{array}{l}\text { Between } \\
\text { groups }\end{array}$ & 2 & 1.793 & .897 & 5.391 & $.011^{*}$ \\
$\begin{array}{l}\text { Within } \\
\text { groups }\end{array}$ & 27 & 4.491 & .166 & & \\
Total & 29 & 6.285 & & \\
$* p<0.05$ & & & &
\end{tabular}

Years of experience. Table 11 presents the Pearson Correlation, the post hoc analysis of the Spearman Rho. The data indicated that there was a correlation between the years of experience as a chief state school officer and the leadership frames mean scores of the respondents. The Pearson Correlation analysis showed that there was a statistically significant relationship between years of experience as a chief state school officer and the leadership frames means at the $p<.05$ and the $p<.001$ levels. Therefore, the null hypothesis was rejected. However, an analysis of the number of years of experience in other administrative positions, and total number of years in an educational setting did not yield statistical significance. 
Table 11

Correlation of Years of Experience as CSSO and Frame Mean

\begin{tabular}{lcc}
\hline Leadership Frame & Correlation Coefficient & $p$ value \\
\hline Structural & .416 & $.022^{*}$ \\
Human Resource & .382 & $.037^{*}$ \\
Political & .451 & $.012^{*}$ \\
Symbolic & .585 & $.001 * *$ \\
\hline$* p<0.05 ; * * p<.001$ & &
\end{tabular}

Question 4. Are there differences between the leadership styles (no-frame, single-frame, paired-frame, and multi-frame) of chief state school officers and selected demographic variables?

As displayed in Table 9, the respondents were identified as predominately using a multiframe leadership style, with all four frames being utilized. The paired-frame leadership style was second, with the symbolic frame being used most often in the pairings. Tables 12, 13, and 14 display the frequency distribution of leadership styles by age, gender, and highest degree earned. The data indicated that there was a statistically significant difference in the leadership styles of chief state school officers $x^{2}(3, \mathrm{n}=30)=14.00, p=.003$. Therefore the null hypothesis was rejected.

Age. The data in Table 12 indicate the distribution of leadership styles of the chief state school officers do vary some by age than from the distribution of all the respondents. The distribution pattern across the leadership style by age tends to be consistent with the pattern of the collective group of respondents except for the 40-49 age category, where the majority of 
these chief state school officers do not have a multi-frame leadership style. The data indicated that there were no statistically significant differences in leadership style by age, $x^{2}(9, \mathrm{~N}=30)=$ $6.52, p=.687$. However, the data trend would indicate the utilization of multi-frame leadership is more frequent in the participants greater than 49 years of age.

Table 12

Leadership Style and Frame Pattern by Age

\begin{tabular}{|c|c|c|c|c|}
\hline \multirow[t]{2}{*}{$\begin{array}{l}\text { Leadership Style/Frame } \\
\text { Pattern }\end{array}$} & $<40(n=2)$ & $40-49(n=6)$ & $50-59(n=14)$ & $>60(n=8)$ \\
\hline & \multicolumn{4}{|c|}{ Frequency (\%) } \\
\hline No-frame & $0(0.0 \%)$ & $2(33.3 \%)$ & $1(7.1 \%)$ & $1(12.5 \%)$ \\
\hline Single-frame & $0(0.0 \%)$ & $1(16.1 \%)$ & $1(7.1 \%)$ & $1(12.5 \%)$ \\
\hline Structural & 0 & 0 & 0 & 0 \\
\hline Human Resource & 0 & 1 & 0 & 1 \\
\hline Political & 0 & 0 & 1 & 0 \\
\hline Symbolic & 0 & 0 & 0 & 0 \\
\hline Paired-frame & $0(0.0 \%)$ & $2(33.3 \%)$ & $3(21.4 \%)$ & $2(25.0 \%)$ \\
\hline Structural/HR & 0 & 1 & 0 & 0 \\
\hline Structural/Symbolic & 0 & 1 & 0 & 0 \\
\hline HR/Political & 0 & 0 & 1 & 0 \\
\hline HR/Symbolic & 0 & 0 & 1 & 1 \\
\hline Political /Symbolic & 0 & 0 & 1 & 1 \\
\hline Multi-frame & $2(100.0 \%)$ & $1(16.1 \%)$ & $9(64.3 \%)$ & $4(50.0 \%)$ \\
\hline Structural/HR/Pol/Sym & 1 & 0 & 7 & 2 \\
\hline Structural/HR/Pol & 1 & 0 & 1 & 0 \\
\hline Structural/HR/Sym & 0 & 0 & 1 & 1 \\
\hline Structural/Pol/Sym & 0 & 1 & 0 & 0 \\
\hline $\mathrm{HR} / \mathrm{Pol} / \mathrm{Sym}$ & 0 & 0 & 0 & 1 \\
\hline
\end{tabular}

Gender. As presented in Table 15, the difference in leadership styles of the chief state school officers does not vary by gender from the distribution pattern of the collective group of respondents. The data indicated that there were no statistically significant differences of 
leadership styles by gender, $x^{2}(3, \mathrm{~N}=30)=.523, p=.914$. Both genders had over $50.0 \%$ of the respondents utilizing a multi-frame leadership style.

Table 13

Leadership Style and Frame Pattern by Gender

\begin{tabular}{|c|c|c|c|c|}
\hline \multirow{3}{*}{$\begin{array}{l}\text { Leadership Style/Frame Pattern } \\
\text { No-frame }\end{array}$} & \multicolumn{2}{|c|}{ Male $(n=19)$} & \multicolumn{2}{|c|}{ Female $(n=11)$} \\
\hline & \multicolumn{4}{|c|}{ Frequency $(\%)$} \\
\hline & 2 & $\mathbf{1 0 . 5}$ & 2 & 18.2 \\
\hline Single-frame & 2 & 10.5 & 1 & 9.1 \\
\hline Structural & 0 & & 0 & \\
\hline Human Resource & 1 & & 1 & \\
\hline Political & 1 & & 0 & \\
\hline Symbolic & 0 & & 0 & \\
\hline Paired-frame & 5 & 26.3 & 2 & 18.2 \\
\hline Structural/HR & 0 & & 1 & \\
\hline Structural/Symbolic & 1 & & 0 & \\
\hline HR/Political & 1 & & 0 & \\
\hline HR/Symbolic & 1 & & 1 & \\
\hline Political /Symbolic & 2 & & 0 & \\
\hline Multi-frame & 10 & 52.6 & 6 & $\mathbf{5 4 . 5}$ \\
\hline Structural/HR/Pol/Sym & 7 & & 4 & \\
\hline Structural/HR/Pol & 1 & & 0 & \\
\hline Structural/HR/Sym & 1 & & 1 & \\
\hline Structural/Pol/Sym & 1 & & 0 & \\
\hline HR/Pol/Sym & 0 & & 1 & \\
\hline
\end{tabular}

Ethnicity. The data indicated that there were no statistically significant differences of leadership style and the demographic variable of ethnicity, $x^{2}(9, \mathrm{~N}=30)=8.472, p=.487$. Again, the majority (90\%) of the chief state school officers identified White, non-Hispanic as their ethnicity. 
Highest degree earned. As presented in Table 14, the differences in leadership style by the chief state school officers do not vary by highest degree earned from the distribution pattern of the collective group of respondents. The category of Bachelor's degree had no data, no chief state school officer identified a bachelor's degree as the highest degree; therefore that category was not included in the analysis. The data indicated that there were no statistically significant differences of leadership style by highest degree earned, $x^{2}(6, \mathrm{~N}=30)=5.63, p=.486$. Regardless of the highest degree earned, the highest frequency count was in the multi-frame category.

Years of experience. A Spearman Rho analysis of the data indicated that there was a correlation between the years of experience as a chief state school officer and leadership style. The Spearman Rho analysis showed a statistically significant relationship between years of experience as a chief state school officer and the leadership style at the $p<.05$ level, $p=.035$. However, an analysis of the number of years of experience in other administrative positions and total number of years in an educational setting did not yield any statistical significance. 
Table 14

Leadership Style and Frame Pattern by Highest Degree Earned

\begin{tabular}{|c|c|c|c|}
\hline \multirow[t]{2}{*}{$\begin{array}{c}\text { Leadership Style/Frame } \\
\text { Pattern }\end{array}$} & Master's $(n=10)$ & Doctorate $(n=18)$ & Other $(n=2)$ \\
\hline & \multicolumn{3}{|c|}{ Frequency $(\%)$} \\
\hline No-frame & $1(10.0 \%)$ & $2(11.1 \%)$ & $1(50.0 \%)$ \\
\hline Single-frame & $0(0.0 \%)$ & $3(16.7 \%)$ & $0(0.0 \%)$ \\
\hline Structural & 0 & 0 & 0 \\
\hline Human Resource & 0 & 2 & 0 \\
\hline Political & 0 & 1 & 0 \\
\hline Symbolic & 0 & 0 & 0 \\
\hline Paired-frame & $2(20.0 \%)$ & $5(27.8 \%)$ & $0(0.0 \%)$ \\
\hline Structural/HR & 0 & 1 & 0 \\
\hline Structural/Symbolic & 0 & 1 & 0 \\
\hline HR/Political & 0 & 1 & 0 \\
\hline HR/Symbolic & 0 & 2 & 0 \\
\hline Political /Symbolic & 2 & 0 & 0 \\
\hline Multi-frame & $7(70.0 \%)$ & $8(44.4 \%)$ & $1(50.0 \%)$ \\
\hline Structural/HR/Pol/Sym & 5 & 5 & 0 \\
\hline Structural/HR/Pol & 1 & 1 & 0 \\
\hline Structural/HR/Sym & 0 & 2 & 0 \\
\hline Structural/Pol/Sym & 0 & 0 & 1 \\
\hline $\mathrm{HR} / \mathrm{Pol} / \mathrm{Sym}$ & 1 & 0 & 0 \\
\hline
\end{tabular}

Question 5. Do the leadership frames (structural, human resource, political, and symbolic) of the chief state school officers differ across the models of educational governance? Table 15 presents the means and standard deviations for the chief state school officers of the United States and the District of Columbia for the four leadership frames (structural, human resource, political, and symbolic) by model of educational governance. 
Table 15

Frame Means by Model of Educational Governance

\begin{tabular}{lcccc}
\hline \multicolumn{1}{c}{$\begin{array}{c}\text { Leadership } \\
\text { Frame }\end{array}$} & $\begin{array}{c}\text { Model One } \\
(n=8)\end{array}$ & $\begin{array}{c}\text { Model Two } \\
(n=8)\end{array}$ & $\begin{array}{c}\text { Model Three } \\
(n=6)\end{array}$ & $\begin{array}{c}\text { Model Four } \\
(n=8)\end{array}$ \\
\cline { 2 - 5 } & $4.25(.92)$ & $3.77(.26)$ & $3.69(.55)$ & $4.17(.24)$ \\
\hline Structural & $4.39(.37)$ & $3.97(.57)$ & $4.03(.32)$ & $4.03(.48)$ \\
Human Resource & $4.30(.52)$ & $3.93(.35)$ & $3.96(.39)$ & $4.09(.54)$ \\
Political & $4.29(.87)$ & $3.91(.55)$ & $4.07(.44)$ & $4.17(.45)$ \\
Symbolic & & & & \\
\hline
\end{tabular}

The mean scores for all the frames were higher for chief state school officers in Model One states than in all of the other models. However, the data indicated that there were no statistically significant differences of frame usage by model of educational governance. Therefore, the null hypothesis was not rejected. However, the data indicated that the Model Two category failed to reach the 4.0 mean necessary to indicate the usage of any leadership frame. Models One and Four each exceeded the 4.0 threshold in all four frames which indicated utilization of all four frames and corresponded to the multi-frame leadership style. The means for the frames in Model Three corresponded to a paired frame leadership style, achieving the 4.0 threshold in the human resource and symbolic frames.

Question 6. Do the leadership styles (no-frame, single frame, paired frame, and multiframe) of the chief state school officers differ across the models of educational governance?

The difference in leadership style by the chief state school officers by model of educational governance do vary some from the distribution pattern of the collective group of respondents. In Model Two, the respondents are evenly distributed across all leadership styles. 
Table 16 summarizes the leadership styles of the chief state school officers by model of educational governance. The data indicated that there were no statistically significant differences of leadership style by model of governance, $x^{2}(9, \mathrm{~N}=30)=9.345, p=.406$.

Therefore, the null hypothesis was not rejected.

Table 16

Leadership Style and Frame Pattern by Model of Educational Governance

\begin{tabular}{|c|c|c|c|c|}
\hline \multirow[t]{2}{*}{$\begin{array}{l}\text { Leadership Style/ } \\
\text { Frame Pattern }\end{array}$} & $\begin{array}{l}\text { Model One } \\
\quad(n=8)\end{array}$ & $\begin{array}{l}\text { Model Two } \\
\quad(n=8)\end{array}$ & $\begin{array}{l}\text { Model Three } \\
\quad(n=6)\end{array}$ & $\begin{array}{l}\text { Model Four } \\
\quad(n=8)\end{array}$ \\
\hline & \multicolumn{4}{|c|}{ Frequency $(\%)$} \\
\hline No-frame & $1(12.5 \%)$ & $2(25.0 \%)$ & $1(16.7 \%)$ & $0(0.0 \%)$ \\
\hline Single-frame & $0(0.0 \%)$ & $2(25.0 \%)$ & $1(16.7 \%)$ & $0(0.0 \%)$ \\
\hline Structural & 0 & 0 & 0 & 0 \\
\hline Human Resource & 0 & 2 & 0 & 0 \\
\hline Political & 0 & 0 & 1 & 0 \\
\hline Symbolic & 0 & 0 & 0 & 0 \\
\hline Paired-frame & $1(12.5 \%)$ & $2(25.0 \%)$ & $2(33.3 \%)$ & $2(25.0 \%)$ \\
\hline Structural/HR & 0 & 0 & 0 & 1 \\
\hline Structural/Symbolic & 0 & 0 & 0 & 1 \\
\hline HR/Political & 0 & 1 & 0 & 0 \\
\hline HR/Symbolic & 1 & 0 & 1 & 0 \\
\hline Political /Symbolic & 0 & 1 & 1 & 0 \\
\hline Multi-frame & $6(75.0 \%)$ & $2(25.0 \%)$ & $2(33.3 \%)$ & $6(75.0 \%)$ \\
\hline Structural/HR/Pol/Sym & 5 & 2 & 1 & 2 \\
\hline Structural/HR /Pol & 0 & 0 & 0 & 2 \\
\hline Structural/HR/Sym & 1 & 0 & 1 & 0 \\
\hline Structural/Pol/Sym & 0 & 0 & 0 & 1 \\
\hline HR/Pol/Sym & 0 & 0 & 0 & 1 \\
\hline
\end{tabular}

\section{Summary}

In summary, chief state school officers who responded to this study, which represented approximately $60 \%$ of the entire population of the chief state school officers, were more likely 
to use a multi-frame leadership approach, followed by a paired-frame approach, a no-frame approach and least likely to use a single-frame approach in their leadership style. Additionally, the chief state school officers were more likely to use the human resource and symbolic frames, and the political frame in descending order, and least likely to use the structural frame.

In relation to the years of experience as a chief state school officer, in other administrative positions, and total years of experience in an educational setting, the respondents had served an average number of 3.82 years as a chief state school officer, with an average of 21.8 years of administrative experience, excluding their years in the current position, and had an average of 31.4 years of experience in an educational setting.

Several statistically significant findings were obtained. There was a significant relationship between the highest degree earned by the chief state school officers and the human resource frame mean score. The difference between the chief state school officers who had earned a doctorate degree and those chief state school officers with a juriss doctor degree was significant at the .009 level, and the difference between the chief state school officers with a master's degree and the juris doctor was significant at the .05 level.

There also were statistically significant relationships between the number of chief state school officers and the identified leadership style, more than half of the respondents (53.3\%) identified a multi-frame leadership style. Additional significance was found between the years as a chief state school officer and leadership frame means and leadership style. The data indicated a statistically significant correlation between the number of years as a chief state school officer and the mean score for each of the four frames. An additional significant relationship was found between the number of years as a chief state school officer and leadership style. 
However, the data did not indicate that there was a statistically significant relationship between the models of educational governance and the chief state school officers' frame mean scores or leadership styles. When the frame mean usage was compared by model, Models One and Four had an average of above 4.0 in all four leadership frames, Model Two did not reach the threshold of a 4.0 in any of the leadership frames and Model Three reached the 4.0 threshold in two of the four frames, human resource, and symbolic frames. 


\section{Chapter Five: Conclusions and Recommendations}

Chapter Five presents a summary of the study, findings, conclusions, and recommendations based on the findings related to the self-perceived leadership styles of chief state school officers and models of educational governance. This chapter is divided into six sections: summary of the study, overview of the problem, description of the chief state school officer, findings related to literature, conclusions, and recommendations.

\section{Summary of the Study}

The conceptual framework for this study is based on the Bolman and Deal $(1984,1991 \mathrm{c}$, 2003), Four-Frame leadership orientation model (structural, human resource, political, and symbolic frames.) The structural frame paradigm considers the organizational architecture, espousing that the correct formal arrangement minimizes problems and maximizes productivity. The human resource frame champions attending to the personal needs of the individuals will address the needs of the organization a "family" perspective pervades. The political frame perspective identifies that there are limited resources and a variety of individual and group needs, therefore competition is to be expected and power is leveraged through flexible alliances, negotiation, and compromise. The symbolic frame espouses that the organizational culture is the glue that binds the organization together and unites people around shared values and beliefs. According to Bolman and Deal (2003), earnest and correct implementation of the leadership frames increases the likelihood of the leader achieving goals and desired outcomes.

Chief state school officers represent an influential yet understudied population of educational leaders. The breadth of their responsibilities includes significant fiscal, human resource, and social justice responsibilities related to the quality of educational opportunities for students across the United States. In any institution, effective leadership is inextricably linked to 
organizational success. Therefore, strong leadership is needed to effectively discharge the responsibilities of the office of chief state school officer. Despite this critical function, until now there has been a marked absence of research about chief state school officers and their leadership styles. The intent of this study was to contribute to the literature about an important population of educational leaders and their leadership styles.

The execution of the duties and responsibilities of the chief state school officers does not happen in a vacuum. Each state has established, through US Constitutional authority, a model of educational governance. Research regarding the different state models of educational governance is also absent from the literature. In addition to determining the leadership styles of the chief state school officers, the study attempted to answer the question of whether there were differences in the leadership styles employed by the chief state school officers based on the different models of state governance.

\section{Overview of the Problem}

The study served to establish baseline data about the leadership styles of chief state school officers and make comparisons between leadership styles and models of educational governance. The study described the leadership styles of the chief state school officers using the Bolman and Deal Leadership Frames Orientations (Self) Survey (Bolman \& Deal, 1990) and through the lenses of several demographic variables: age, ethnicity, gender, highest degree earned, and years of experience as a chief state school officer, administrative experience, and total years of educational experience. These demographic variables were selected to make comparisons to previous research that contained similar demographic variables. This descriptive study utilized a self-reported, web-based survey instrument to answer each of the research questions. The final element of the research study was to make comparisons between the 
leadership styles of the chief state school officers and state models of educational governance. Each of the research questions, the results from this study, and comparisons with other research are discussed in the Findings Related to Literature section.

\section{Description of the Chief State School Officers}

A snapshot of the typical state school officer was developed from the descriptive statistics. The chief state school officers who responded to the survey tended to be White, nonHispanic (90\%) males (63.3\%). A significant majority of chief state school officers were over the age of $49(73.4 \%)$. The average number of years as a chief state school officer was 3.82 years with an average of 21.8 years of administrative experience. The majority $(60 \%)$ held a doctorate degree and had an average of 31.4 years of experience in an educational setting.

Findings Related to the Literature

The findings presented in this section are based on the results of the analysis of data received from the survey process of the chief state school officers regarding the six research questions guiding this study. A comparison to previous research on the same population of educational leaders could not be conducted because of the lack of literature about chief state school officers. In response, research about the leadership styles of college presidents, college administrators, and local school district superintendents was referenced.

Question 1. What are the leadership frames (structural, human resource, political, and symbolic) of the chief state school officers of the United States and the District of Columbia?

The entire population of chief state school officers was surveyed for this study (51), but only 30 usable responses were obtained. The chief state school officers who responded were more likely to use the human resource, symbolic, and political frames, and less likely to use the structural frame. The mean scores for the frames in the corresponding order were 4.11, 4.11 and 
4.08. The mean score for the structural frame (3.99) failed to reach the 4.0 threshold necessary to indicate the usage of that frame in the total group of respondents. The mean score of 4.0 corresponds to a response that indicates the frame is used "often." A mean greater than 4.0 indicates that on at least one of the questions related to the particular frame, the respondent identified the characteristic or behavior was "always" demonstrated.

The results of this study align with the findings on college administrators and presidents in relation to the use of the human resource frame. Borden (2000), McArdle (2008), Runkle (2004), Russell (2000), and Spyawaka (2008) all found the human resource frame had the highest mean score and was therefore the predominant frame used. In Monahan (2004), the use of the human resource frame was statistically significant at the .05 level. In studies of local superintendents, Edmunds (2008), Deluca (2009), and Ward (2006), all showed the predominant frame was the human resource frame. In Frick's (1996) study of Southern California superintendents, the human resource frame received the highest mean score and was statistically significant at the .0001 confidence level.

The results of this study, in relation to the use of the structural frame, contradict the majority of the studies with which this research was compared. The structural frame was the least used frame among the chief state school officers and actually did not meet the 4.0 threshold to indicate use of the frame. Additionally, the results for this frame were more diverse among studies in the literature. Bordern (2000) and Spyawaka (2008) both had college and university respondents who identified the structural frame as the second most used frame. While the community college presidents in McArdle (2008) and Runkle (2004) identified the structural frame as the least used frame. 
The studies about local superintendents were also equally diverse. Deluca (2009) and Frick (1996) found the structural frame to be the second most used frame as indicated by the second highest mean score. Additionally, Frick (1996) found the structural frame was the one area of statistically significant difference at the .05 confidence level among the leadership style categories. In Ward (2006), the superintendents self-identified the structural frame as their second most used frame; however, the principals who completed the assessment of the superintendents using the Leadership Frames Orientations (Other) Survey version of the instrument, identified the structural frame as the third most used frame by the superintendents. Edmunds (2007) found in her study of female superintendents, the structural frame was also the third most used frame.

The results of the frame use of both the symbolic and political frames, in comparative research, are also mixed. In McArdle (2008) and Russell (2000), the mean scores for both the symbolic frame and the political frame were nearly identical; there was only a .01 difference between the scores. In Frick (1996), the mean scores of the superintendents were the same for both frames.

The college administrators in Spyawaka (2008) and Borden (2000) identified the symbolic frame as the third highest mean score. However, in both instances the mean score was not above a 4.0 to actually indicate utilization of that frame. In Ward (2006) and Deluca (2009) the symbolic frame had the second lowest mean score among the superintendents. Edmunds (2007) found the female superintendents used the symbolic frame second most and the political frame had the lowest mean score.

Question 2. What are the leadership styles (no-frame, single-frame, paired-frame, and multi-frame) of the chief state school officers of the United States and the District of Columbia? 
The majority of the chief state school officers (53.3\%) identified a multi-frame leadership style. Of those 16 chief state school officers, 10 utilized all four frames, which corresponded to $33 \%$ of the entire population of respondents. The second most utilized leadership style was the pairedframe with seven $(23.3 \%)$ respondents. In the paired-frame group, the most common frame was the symbolic frame, which was present in five of the seven responses. The third most utilized leadership style was the no-frame leadership style with four (13.3\%) of the respondents having not identified any frame usage with a mean score of 4.0 or greater in any of the leadership frames. The least used leadership style was the single-frame leadership style, with only three respondents having been identified with this leadership style.

In relation to the literature, the results of this study compliment some studies and contradict others. Both Monahan (2004) and Ogu (2006) found that the presidents used the multi-frame approach to leadership. Monahan's (2004) results indicated that $43.7 \%$ of the presidents used a multi-frame approach, followed by a paired-frame, then single-frame, and finally no-frame. The use of the multi-frame leadership style by presidents was also found to be statistically significant. Ogu (2006), in his study of Dominican college presidents, found that all the six presidents in the study displayed a multi-frame leadership style. However, in Bensimon (1989), the majority of the presidents (41\%) utilized the single-frame leadership style, followed by the paired-frame (34\%) and finally the multi-frame leadership style (25\%).

Question 3. Are there differences between the leadership frames of chief state school officers and select demographic variables (age, gender, ethnicity, highest degree earned, and years of experience as a chief state school officer, administrative experience, and total years of educational experience)? 
Age. In this study, the age of the chief state school officer may have been a factor in leadership frame usage even though the data indicated that there were no statistically significant differences of frame by age category. The chief state school officers were divided into four categories: under 40, 40-49, 50-59, and over 60. The largest number of chief state school officers, 14, fell into the age group of 50-59, the second largest group were the administrators over the age of 60 , which totaled eight. The trend of the data indicated that the age category 40 49 failed to reach the 4.0 mean necessary to indicate the usage of any leadership frame, whereas the participants in both the 50-59 and over 60 categories had mean scores that indicated usage of all four frames.

In Borden (2000), a statistically significant relationship was identified between age and the political frame usage. The analysis of variance conducted on the sample size of 146 administrators, and the Bonferroni and Scheffe post hoc tests all indicated a significant relationship between age and the political frame usage. The campus administrators over the age of 60 had significantly higher mean scores in the political frame than the administrators ages $50-59$.

Gender. In this study, the use of frames by gender did not yield any statistically significant differences. However, the mean score for the political frame for males was higher than the mean score for females, 4.10 and 4.05 respectively. The male chief state school officers did not have a mean score over a 4.0 for the structural frame that would indicate usage of that frame. Whereas, the female chief state school officers met the 4.0 threshold for all four frames with the human resource being the highest at 4.22 and the political frame mean was the second lowest at 4.05 . 
The results from this study support the studies by DeFrank-Cole (2003) and McArdle (2008) on college presidents. DeFrank-Cole (2003), in her study of West Virginia college and university presidents found no statistically significant differences between female and male presidents in relation to frame use. However, the political frame was used slightly more by the male presidents than by the female presidents. McArdle (2008) also did not find a statistically significant difference in gender and frame usage in her study of college presidents.

Other studies have found statistically significant differences between genders. Frick (1996) found a statistically significant higher mean score of the symbolic frame use by female superintendents. Kolb (2009), in his study of Texas superintendents, also found a statistically significant difference between the mean scores in each of the four frames between the female superintendents and the male superintendents. In every instance, the female superintendents had statistically significant higher mean scores than the males. In the current study, the number of females was low and may have contributed to the lack of significant differences between the genders.

Ethnicity. The analysis of the ethnicity of the chief state school officers and frame usage did not yield statistically significant differences. In part, due to the uneven distribution of ethnicity in the respondents, the majority of the chief state school officers who responded to the survey were, White, non-Hispanic (90\%). Additionally, a comparison with previous research could not be made, as no studies were found that included an analysis of the leadership frame use and the ethnicity of the respondents.

Highest degree earned. A relationship between the highest degree earned and the mean score on the human resource frame was found. The statistically significant difference was present between the chief state school officers who held a master's degree or a doctorate degree 
and the chief state school officers who held a juris doctor degree. The doctorally prepared chief state school officers had the highest mean in the human resource frame $(M=4.24, S D=.38)$; the remaining three means were also all above the 4.0 threshold. Of the chief state school officers who held a Master's degree, the highest mean was the symbolic frame mean $(M=4.36, S D=$ $.33)$, followed by the political frame mean $(M=4.20, S D=33)$. The Juris Doctor trained chief state school officers only showed utilization of the political frame; however, there were only two chief state school officers in this category.

The relationship between frame use and the highest degree earned have been mixed. Sypawka (2008) did not find a statistically significant relationship between the highest degree earned of the North Carolina campus based administrators and frame usage. However, in his study, the doctorally trained campus administrators only demonstrated usage of two frames, the structural frame and the human resource frame. Whereas, the administrators at the bachelor level, self-reported use of all four frames.

In Borden (2000), the relationship between highest degree earned and the symbolic frame usage yielded conflicting results. One analysis found a statistically significant relationship between the highest degree earned and the symbolic frame usage of the campus administrators. However, the post-hoc analysis did not indicate a significant difference between the respondents' level of education and symbolic frame usage. No other significant relationship was found between highest degree and the other frames. However, Kolb (2009) found the superintendents who held a doctoral degree had statistically significant mean scores in all of the frames in comparison with the superintendents who did not.

Years of experience as chief state school officer. In this study, the years of experience as a chief state school officer and frame mean was statistically significant for all four frames. The 
results from this study differ from the results of Sypawaka (2008) and Borden (2000). In neither study was a statistically significant relationship between years of experience working as a dean and self-perceived leadership orientation frame usage found. McArdle (2008) also did not discover a significant relationship between years of experience and frame usage of college presidents.

Total number of years in administration and in an educational setting. An analysis of the number of years of experience in other administrative positions and the total number of years in an educational setting did not yield statistical significance. Borden (2000) did not find any statistically significant relationships between the total number of years in administration and frame usage. With a similar demographic variable, Sypawka (2008) sought to determine if there was a statistically significant relationship between the frame usage and prior years of business experience among the division deans in the North Carolina. The results of the study indicated that there was not a significant relationship between the variables of frame usage and previous business experience.

Question 4. Are there differences between the leadership styles of chief state school officers and selected demographic variables?

This study found that chief state school officers identified using predominately a multiframe leadership style, with all four frames being utilized. Of the respondents, $53.3 \%$ or 16 chief state school officers self-identified a multi-frame leadership style. The second most used leadership style was the paired-frame leadership style, with seven chief state school officers or $23.3 \%$ of the respondents utilizing this frame. The least used leadership style was the singleframe leadership style, $10 \%$ or three chief state school officers reported using this style of 
leadership. The data indicated that there was a statistically significant difference in the leadership styles of chief state school officers, $x^{2}(3, \mathrm{~N}=30)=14.00, p=.003$.

The results in this study align with the results of Monahan (2004), Ogu (2006), and Welch (2002), in comparison with college administrators. Monahan (2004) concluded that $43.7 \%$ of the presidents at Masters I institutions reported using a multi-frame leadership orientation. Additionally, the multi-frame leadership style was statistically significant at the .05 level. Ogu (2006) concluded that all the presidents in the study utilized a multi-frame leadership orientation. The female college presidents in Welch (2002) also primarily used a multi-frame leadership style.

The results of the chief state school officers are in contrast to results reported by Bensimon (1989). In her study, the majority (40\%) of the college presidents identified a singleframe orientation, whereas $34 \%$ (11) college presidents identified a paired-frame orientation. Frick (1996) in her study of Southern California superintendents found that approximately $56 \%$ of respondents identified a single-frame leadership style. Additionally, $19 \%$ of the respondents used the paired-frame and only $25 \%$ used a multi-frame leadership style.

Age. While, the analysis of age of the chief state school officers and leadership frame usage did not yield any statistically significant results, the results indicated that the predominant leadership style was the multi-frame leadership style with all four frames being utilized. The second most common leadership style was the paired-frame.

The leadership styles distribution pattern is similar among the 50-59 age category, the over 60 category, and the under 40 category, a multi-frame leadership style predominately, followed by paired-frame leadership style. The pattern deviates in the 40-49-age category; in this age group, the paired-frame leadership style is primary used, followed by the no-frame 
leadership style. The trend would indicate that the utilization of multi-frame leadership is more frequent in the populations greater than 49 years of age.

In Monahan (2004), the presidents were divided into two categories, under 60 and over 60. The presidents who were younger, less than 60 years of age, $46.6 \%$ used a multi-frame leadership style and $24.1 \%$ used a paired-frame leadership style. Of the presidents who were older than 60 years of age, $41.2 \%$ utilized a multi-frame orientation and $20.2 \%$ utilized a pairedframe leadership style. However, the differences between the two groups did not yield a statistically significant difference in leadership styles.

Gender. This study did not yield any statistically significant differences between the leadership styles of the chief state school officers and gender. A multi-frame leadership style was the predominant leadership style for both male and female chief state school officers. In Monahan (2004), 77\% of the presidents in the study were male. Both genders employed a multi-frame leadership style most frequently. However, the female presidents used this leadership style $7.1 \%$ more often than did male presidents. The differences between the leadership styles of the presidents were not statistically significant.

Ethnicity. The analysis of the ethnicity of the chief state school officers and leadership style did not yield statistically significant differences. Again, this is in part due to the uneven distribution of ethnicity in the respondents. However, in Monahan (2004), Caucasian presidents utilized the no-frame, single-frame, and paired-frame leadership styles more frequently than Non-Caucasian presidents. The paired human resource-symbolic frame and the politicalsymbolic frame were the exceptions, as Caucasian presidents utilized these specific styles fewer than Non-Caucasian presidents. 
Highest degree earned. The data indicated that there were no statistically significant differences in leadership styles by highest degree earned. Regardless of the highest degree earned, the predominant leadership style of the chief state school officers was the multi-frame leadership style. In Monahan (2004), no statistically significant difference was found between the leadership styles of the presidents and the highest degree earned. In the study, $89.7 \%$ of the presidents held an earned doctorate degree and identified a multi-frame leadership style 5.8\% more than the presidents without one. Additionally, the presidents with a doctorate degree used all four frames in their leadership style $16.6 \%$ more than presidents without a doctoral degree.

Years of experience as chief state school officer. The years of experience as a chief state school officer and leadership style were statistically significant. The data indicated that the longer an individual served as a chief state school officer the more likely they were to use a multi-frame leadership style. The results of this study differ from Monahan (2004). In Monahan (2004), the difference in leadership styles between the presidents with less than 10 years of experience and the presidents with more than 11 years of difference was not statistically significant. Both groups tended to use a multi-frame leadership style, $43 \%$ of the presidents with less than 10 years of presidential experience, and $46 \%$ of the presidents with more than 11 years of experience were multi-frame leaders. In Monahan's (2004) study, the experience of the presidents was grouped into categories for analysis. In this study, the analysis of the years of experience as chief state school officer utilized continuous data, in part because the differences in years of experience were not distinct enough for categorization.

Monahan (2004) also analyzed the leadership styles of presidents and number of presidencies held. Two categories were created for analysis: first time presidents, and presidents with more than one presidency. There were a large number of first time presidents 
(70.5\%). Second presidencies accounted for $20.1 \%$, and respondents who had three or more presidencies represented $9.1 \%$ of the surveyed population. There were no statistically significant differences between the leadership style of the president and the number of presidencies. The multi-frame leadership style was the most prevalent style employed by both groups. However, the respondents who had multiple presidencies utilized this style $4.8 \%$ more often and the respondents with multiple presidencies exercised the full four-frame style more frequently (4.6\%) than first-time presidents.

Total number of years in administration and in an educational setting. An analysis of the number of years of experience in other administrative positions, and total number of years in an educational setting did not yield statistical significance.

Question 5. Do the leadership frames of the chief state school officers differ across the models of educational governance (Model One, Model Two, Model Three, and Model Four)?

There were no statistically significant differences in mean scores of the leadership frames across the models of educational governance. The mean score for the human resource frame across all the models of educational governance indicated use of this frame in three of the models, Model One, Model Three, and Model Four. The mean score for the human resource frame for Model Two was 3.97, which did not meet the 4.0 threshold to indicate use of this frame. Model One had the highest score of 4.39 and Model Three and Model Four had the same score of 4.03. Englert (2008), in his study of rural community college presidents, found a statistically significant difference in the use of the human resource frame usage between presidents serving elected boards in comparison with presidents serving appointed boards. Presidents serving appointed boards rated the human resource frame significantly higher than did presidents serving elected boards. 
The mean score of the structural frame indicated use of this frame in two of the models, Model One and Model Four, with respective mean scores of 4.25 and 4.17. The scores for Model Two and Model Three were below 4.0, 3.77 and 3.69 respectively. The mean score of the political frame indicated use of this frame in two of the models, Model One and Model Four, with respective mean scores of 4.30 and 4.09. The scores for Model Two and Model Three were below 4.0, 3.93 and 3.96 respectively. Finally, the mean score of the symbolic frame indicated use of this frame in three of the models, Model One, Model Three and Model Four, with respective mean scores of 4.29, 4.07 and 4.17. The score for Model Two was 3.91. The manner by which the chief state school officer is selected did not appear to have an influence on the chief state school officers' usage of or aptitude for the four leadership frames.

Question 6. Do the leadership styles of the chief state school officers differ across the models of educational governance (Model One, Model Two, Model Three, and Model Four)?

Model One and Model Four each exceeded the 4.0 threshold in all four frames which indicated utilization of all four frames and corresponded to the multi-frame leadership style. The mean scores for the frames in Model Three corresponded to a paired-frame leadership style, achieving the 4.0 threshold in the human resource and symbolic frames. The data indicated that the Model Two category failed to reach the 4.0 mean necessary to indicate the usage of any leadership frames, or the no-frame leadership style.

Monahan (2004) in the study of Master's I presidents found that presidents primarily utilized the multi-frame leadership style regardless of the type of control, whether it be a private or public institution of higher education. However, presidents of public institutions utilized the multi-frame style $7 \%$ more frequently than presidents of private institutions. Conversely, presidents of private institutions utilized a paired-frame leadership style as the second highest 
style $6 \%$ more than presidents of public institutions. The paired-frame of human resourcesymbolic was employed 7\% more in private institutions; however the structural-human resourceframe was utilized $6 \%$ more frequently in public institutions. The single-frame of human resources was practiced $7 \%$ more in public institutions than in private institutions. 


\section{Conclusions}

\section{Recommendations for Practice}

The chief state school officers who do not utilize a multi-frame leadership style could be provided professional learning opportunities to develop into multi-frame users. The research from this study found a relationship between years of experience as a chief state school officer and utilization of all the frames and the multi-frame leadership style. What was not able to be determined was whether the chief state school officers possessed a multi-frame leadership orientation prior to assuming the position therefore allowing them permanency in the position or whether while in the position of chief state school officer they developed a multi-frame leadership style. Either way, a multi-frame leadership style enables leaders to be more effective as a result of their understanding of the multiple dimensions of an organization and utilize strategies to navigate through those dimensions.

The Council of Chief State School Officers (CCSSO) could also be instrumental in providing focused leadership development opportunities for chief state school officers. The research indicated that the majority of the respondents in this study who were in the age category of 40-49 years of age did not utilize a multi-frame leadership style. Another recommendation would be for the CCSSO to facilitate mentoring relationships from among former chief state school officers. Having access to the experience of a previous chief could have the potential of accelerating the years of experience of chief state school officer that was shown to have a statistically significant relationship with a multi-frame leadership style.

The results of this study did not show a relationship between the model of educational governance and the leadership frame usage or leadership style of the chief state school officer. However, regardless of the selection process attributed to the model of educational governance, a 
multi-frame leadership style would be beneficial to the chief state school officer. The selection process could involve an assessment of the individual's use of and aptitude for the Bolman and Deal (1991c, 2003) leadership frames and leadership styles.

The population of chief state school officers is predominately White, non-Hispanic. One area of focus for the Council of Chief State School Officers could be to work with states and individuals to move the population of chief state school officers to be more aligned with the general population in regards to the ethnic and racial make-up of the chief state school officers.

\section{Recommendations for Further Study}

As with most research, the findings raise many questions that require continued investigation.

The following recommendations are offered to guide researchers in the continuation of this line of study.

1. Additional studies about the leadership styles of chief state school officers, which include the perceptions of others, e.g., board members, direct reports, individuals in state education agency, practitioners in field, would be beneficial to the literature. Effective leadership is important in accomplishing complex and lofty goals necessary to provide quality educational opportunities for students. The $360^{\circ}$ perspective of leadership would portray a more accurate picture of leadership styles and practices.

2. Measures of educational effectiveness would contribute to the research on the leadership styles of chief state school officers. Creating a definition of elements of effectiveness will allow the analysis of the leadership behaviors or leadership characteristics that most influence educational effectiveness and outcomes. 
3. The creation of measures of educational effectiveness for research purposes could then be used for the purpose of evaluating the models of educational governance for effectiveness and educational impact.

4. Additional research on the models of educational governance would also be beneficial for the evaluation and assessment of models of educational governance.

\section{Concluding Remarks}

In conclusion, the results of the present study indicated chief state school officers tended to be White, non-Hispanic males. A significant majority was over the age of $49(73.4 \%)$ with an average of 3.82 years of experience as a chief state school officer and 21.8 years of administrative experience. The majority $(60 \%)$ held a doctorate degree and had an average of 31.4 years of experience in an educational setting.

The predominant leadership orientation of the chief state school officers was a multiframe leadership style (53.3\%), followed by a paired-frame leadership style (23.3\%) with the least likely style being the single-frame (10.0\%). A statistically significant relationship was found between the human resource frame mean and the highest degree earned. The number of chief state school officers having identified a multi-frame leadership style was also statistically significant. Additionally, this study determined that a significant relationship existed between the years of experience as a chief state school officer and leadership frame use and leadership style. It appeared that the longer an individual is a chief state school officer the more likely they are to utilize all four frames and therefore possess a multi-frame leadership style. However, the study could not determine whether there was a cause and effect relationship between these two variables. In other words, did the chief state school officers begin as multi-frame users and thus 
stay longer in the position or did they become more multi-frame users the longer they remained in the position.

There are limits to the conclusions drawn from self-report research. An analysis of the perceptions of others regarding the leadership style and practice of a chief state school officer in addition to the self-perceptions would further contribute to the literature about educational leadership and about chief state school officers. Additionally, a response rate, closer to $80 \%$ would further elucidate this population of educational leaders. This study is the first investigation about an important group of leaders who had not been previously studied and the first time this population has been studied using the Bolman and Deal Framework.

\section{Researcher Reflections}

Bolman and Deal refer to the leadership frames, the windows through which to view an organization from multiple perspectives. The premise is that the more a leader is able to able reframe, or views the elements of an organization from multiple perspectives, the more effectively they are able to lead and manage the organization. The frames, for this researcher, may be understood as languages. The more the leader of an organization is multi-lingual, the better he or she is able to communicate with the individuals within the organization who speak multiple organizational languages or dialects. Bolman and Deal (1991c, 2003) identify the elements of each language and offer the opportunity for individuals to increase their organizational language fluency.

This study looked at the leadership styles of chief state school officers with one of the variables of models of educational governance. Previous researchers elected to look at other variables affiliated with leadership, such as stress management, readiness to change, and reflection ability. Russell (2000) determined that the more the respondents utilized a multi-frame 
leadership style, the less stressed they reported. Runkle (2004) concluded the community college presidents were better able to utilize each of the four frames due to their high level of self-awareness about their values and the importance placed on value reflection. Frick (1996) found significant relationships between frame use and readiness to change variables. It may be concluded that possessing a multi-frame leadership style enables leadership effectiveness by allowing leaders to execute the responsibilities of the position in a manner that assists them in managing the stress, and making the needed changes to the organization, with permanency in the position.

In this study, the data indicated a positive correlation between a multi-frame leadership style and the years of experience as a chief state school officer. What the data did not show was whether the chief state school officers who initially possessed a multi-frame leadership style were able to remain longer in the position, or if the nature of the position influenced the creation of multi-frame leaders. It may be concluded that chief state school officers with a multi-frame leadership style may have been able to remain in the position because they were able to manage the stress of the position, were more able to initiate change in the organization, and their leadership style was influenced by self-awareness and values reflection. 


\section{References}

Argyris, C. (1957). Personality and organization: Conflict between the individual and the organization. New York: Harper \& Row.

Argyris, C. (1964). Integrating the individual and the organization. New York: Wiley.

Bass, B. (1981). Stogdill's handbook of leadership. New York: The Free Press.

Bass, B. (1996). A new paradigm of leadership: An inquiry into transformational leadership. Alexandria, VA: U.S. Army Research Institute for the Behavioral and Social Sciences.

Bensimon, E. (1989). The meaning of "good presidential leadership": A frame analysis. Review of Higher Education, 12(2), 107-123.

Blackmore, J. (2002). Leadership for socially just schooling: More substance and less style in high-risk, low-trust times? Journal of School Leadership, 12, 198-222.

Bolman, L. (2010). Research using leadership orientations survey instrument. Retrieved from http://leebolman.com/orientations.htm.

Bolman, L., \& Deal, T. (1984). Modern approaches to understanding and managing organizations. San Francisco: Jossey-Bass.

Bolman, L., \& Deal, T. (1990). Leadership Orientation (Self) Instrument. Retrieved from http://leebolman.com/orientations.htm.

Bolman, L., \& Deal, T. (1991a). Images of leadership (NCEL Occasional Paper No. 7). Nashville, TN: National Center for Educational Leadership.

Bolman, L., \& Deal, T. (1991b). Leadership and management effectiveness: A multi-frame, multi-sector analysis. Human Resource Management, 30(4), 509-534. 
Bolman, L., \& Deal, T. (1991c). Reframing organizations: Artistry, choice, and leadership. San Francisco: Jossey-Bass.

Bolman, L., \& Deal, T. (2003). Reframing organizations: Artistry, choice, and leadership (3 ${ }^{\text {rd }}$ ed.). San Francisco: Jossey-Bass.

Borden, M. P. (2000). Leadership orientations of area campus administrators in Florida's state university and community college systems: A frame analysis. (Doctoral dissertation). Retrieved from ProQuest Digital Dissertations. (AAT 9990629)

Burns, J. M. (1978). Leadership. New York: Harper \& Row.

Campbell, R., Cunningham, L., Nystrand, R., \& Usdan, M. (1980). The organization and control of American schools ( $4^{\text {th }}$ ed.). Ohio: Charles E. Merrill Publishing Co.

Campbell, R., \& Mazzoni, T. (1976). State policy making for the public schools: A comparative analysis of policy making for the public schools in twelve states and a treatment of state governance models. University of Michigan: McCutchan Pub. Corp.

Clark, K. E., \& Clark, B. C. (1992). Introduction. In K.E. Clark, M.B. Clark, \& D. P. Campbell (Eds.), Impact Leadership (177-187). North Carolina: Center for Creative Leadership.

Colasanti, M. (2007). Education Commission of the States, State Notes, Governance Boards/Chiefs/Agencies: Qualifications for chief state school officers. Retrieved from http://www.ecs.org/clearinghouse/73/24/7324.htm.

Council of Chief State School Officers (2011). Meet the Chiefs. Retrieved from http://www.ccsso.org/Who We Are/Meet the Chiefs.html.

Curphy, G. J. (1992). An empirical investigation of the effects of transformational and transactional leadership on organizational climate, attrition, and performance. In K.E. 
Clark, M.B. Clark, \& D. P. Campbell (Eds.), Impact Leadership (pp. 177-187). North Carolina: Center for Creative Leadership.

DeFrank-Cole, L. M. (2003). An exploration of the differences in female and male selfperceptions of presidential leadership styles at colleges and universities in West Virginia (Unpublished doctoral dissertation). University of Pittsburgh, Pittsburgh.

DeLuca, S. (2009). Leadership orientation style and use of power: A study of New Jersey male superintendents. (Doctoral dissertation). Retrieved from ProQuest Digital Dissertations. (AAT 3437335)

Department of the Interior, Census Office (1902). Twelfth Census of the United States, Taken in the Year 1900. Retrieved from http://www2.census.gov/prod2/decennial/documents/ 33405927v2ch05.pdf.

Edmunds, M. (2008). The female superintendency: Reframing our understanding of women's leadership styles and behaviors. (Doctoral dissertation). Retrieved from ProQuest Digital Dissertations. (AAT 3319297)

Englert, M. G. (2008). Leadership orientations of rural community college presidents serving appointed or elected independent governing boards: A four-frame analysis. (Doctoral dissertation). Retrieved from ProQuest Digital Dissertations. (AAT 3321274)

Evans, M. (1969). Convergent and discriminate validities of the Cornell job descriptive index and a measure of goal attainment. Journal of Applied Psychology, 55, 102-106.

Evans, M. (1970). The effects of supervisory behavior on the path-goal relationship. Organizational Behavior and Human Performance, 5, 277-298. 
Evans, M. (1974). Extensions of path-goal theory of motivation. Journal of Applied Psychology, $59,172-178$.

Fiedler, F., (1967). A theory of leadership effectiveness. New York: McGraw-Hill.

First, P., \& Quaglia, J. (1990). The evolving roles of the state boards of education, state education agencies, and chief state school officers (Occasional Paper Series No. 8). Orono, Maine: University of Maine, College of Education.

Flak, T. M. (1998). An inquiry into the leadership orientations of selected women school superintendents. (Doctoral dissertation). Retrieved from OCLC FirstSearch. (AAT 9920823)

Fleming, N. J. B. (2003). A study of principal and teacher judgment of principal leadership orientations. (Doctoral dissertation). Retrieved from ProQuest Digital Dissertations. (AAT 3094565)

French, J., \& Raven, B. (1959). The bases of social power. In Cartwright, D. (Ed), Studies in social power (pp.150 - 167). University of Michigan, Institute for Social Research.

Frick, D. R. (1996). A causal-comparative study of the leadership orientation frames of superintendents and their perceptions about educational change. (Doctoral dissertation). Retrieved from ProQuest Digital Dissertations. (AAT 9626237)

Fronczek, P. \& Johnson, P. (Aug. 2003). Occupations: 2000. Census 2000 Brief. U.S. Census Bureau, Washington, DC. Retrieved from http://www.census.gov/prod/2003pubs/c2kbr25.pdf.

Fuller, E., \& Pearson, J. (1969). Education in the states: Nationwide development since 1900. Washington, DC: National Education Association of the United States. 
Fultan, M. (2008). Education Commission of the States, State Notes, Governance Boards/Chiefs/Agencies: State Education Governance Models. Retrieved from http://www.ecs.org/clearinghouse/77/78/7778.pdf.

Furman, G. C., \& Gruenewald, D. A. (2004). Expanding the landscape of social justice: A critical ecological analysis. Education Administration Quarterly, 40(1), 47-76.

Gay, L., Mills, G., \& Airasian, P. (2006). Educational research: Competencies for analysis and applications $\left(8^{\text {th }}\right.$ ed). New Jersey: Pearson Education, Inc.

Gewirtz, S. (1998). Conceptualising social justice in education: Mapping the territory. Journal of Educational Policy, 13(4), 469-484.

Goodman, J. (1989). Education for critical democracy. Journal of Education, 171(2), 88-116.

Halpin, A., \& Winer, J. (1957). A factorial study of the leader behavior descriptions. R.M. Stogdill \& A. E. Coons (Eds), Leader Behavior: Its description and measurement (Research Monograph No. 88, pp.39-51). Columbus: Ohio State University, Bureau of Business Research.

Hansen, K., \& Morphet, E. (1970). State organization for education: Some emerging alternatives. In E. L. Morphet, \& D. L. Jesser (Eds.), Emerging state responsibilities for education (pp. 47-73). Denver, Colorado: Improving State Leadership in Education.

Harris, S. (1973). State departments of education, school boards, and chief state school officers (DHEW Publication No. OE-73-07400). Washington, DC: US. Government Printing Office. 
Harris, S. (1983). Educational governance in the states: A status report on state boards of education, chief state school officers, and state education agencies. Washington, DC: The Council of Chief State School Officers.

Hersey, P., \& Blanchard, K. (1969). Management of organizational behavior: Utilizing human resources. New Jersey: Prentice-Hall.

Hinkin, T. R., \& Schriesheim, C. A. (1989). Development and application of new scales to measure the French and Raven (1959) bases of social power. Journal of Applied Psychology, 74, 561-567.

Hollander, E. (1980) Leadership and social exchange. In K. J. Gergern, M. S. Greenberg, \& R. H. Willis (Eds.), Social exchange: Advances in theory and research (pp. 103-118). New York: Plenum Press.

House, R. (1971). A path goal theory of leader effectiveness. Administrative Science Quarterly, $16,321-339$.

House, R. (1977). A 1976 theory of charismatic leadership. In J. G. Hunt and L. L. Larson (Eds.), Leadership: The cutting edge (189-207). Carbondale: Southern Illinois University Press.

House, R. (1996). Path-goal theory of leadership: Lessons, legacy and a reformulated theory. Leadership Quarterly, 7(3), 323-353.

Hoy, W., \& Miskel, C. (2005). Educational administration: Theory, research, and practice $\left(7^{\text {th }}\right.$ ed.) New York: McGraw-Hill.

Jacobs, T. (1970). Leadership and exchange in formal organizations (HumRRO Technical Report No. 71-25). Arlington, VA. 
Keesecker, W. (1950). State boards of education and chief state school officers. Washington, DC: US Government Printing Office.

Kerr, S., \& Jermier, J. (1978). Substitutes for leadership: Their meaning and measurement. Organizational Behavior and Human Performance, 22, 375-403.

Kolb, C. S. (2009). Perception of the use of leadership frames by male and female superintendents in Texas by subordinate top-ranking school administrators. (Doctoral dissertation). Retrieved from ProQuest Digital Dissertations (AAT 3431772)

Lewis, C. (1983). Educational governance in the states: A status report of state boards of education, chief state school officers, and state education agencies. Washington, D. C.: Council of Chief State School Officers.

Likert, R. (1961). New patterns of management. New York: McGraw-Hill.

Likert, R. (1967). The human organization: Its management and value. New York: McGrawHill.

Maier, N. (1963). Problem-solving discussions and conferences: Leadership methods and skills. New York: McGraw-Hill.

Mann, H. (1842). Twelfth annual report of the board of education, together with the twelfth annual report of the secretary of the board. Boston: Dutton and Wentworth, State Printers.

McArdle, M. K. (2008). Leadership orientations of community college presidents and the administrators who report to them: A frame analysis. (Doctoral dissertation). Retrieved from ProQuest Digital Dissertations. (AAT 3335355) 
Messer, J. E. (2002). Elementary principal leadership orientations and selected professional and school variables. (Doctoral dissertation). Retrieved from ProQuest Digital Dissertations. (AAT 3042963)

Miller, M. (2007). Transformational Leadership and Mutuality. Transformation, 24(3/4), 180192.

Miner, J. (2005). Essential theories of motivation and leadership. New York: M. E. Sharp.

Mintzberg, H. (1973). The nature of managerial work. New York: Harper \& Row Publishers.

Mitra, D. (2011). Pennsylvania's best investment: The social and economic benefits of higher education. Retrieved from http://www.elcpa.org/BestInvestment_Full_Report_6.27.11.pdf.

Monahan, M. L. (2004). Leadership frames of presidents of Master I Higher Education Institutions. (Doctoral dissertation). Retrieved from ProQuest Digital Dissertations. (AAT $3152275)$

Murphy, J. (1980). State leadership in education: On being a chief state school officer. Washington, DC: Institute for Educational Leadership.

National Association of State Budget Officers (2012). State Expenditure Report: Examining fiscal 2010-2012 state spending. Retrieved from http://www.nasbo.org/sites/default/files/State\%20Expenditure\%20Report 1.pdf.

No Child Left Behind Act of 2001, 20 U. S. C. $§ 6301(2002)$.

Ogu, E. N. (2006). Leadership styles of Dominican college presidents at four-year institutions of higher learning. (Doctoral dissertation). Retrieved from ProQuest Digital Dissertations. (AAT 3226849) 
Oliff, P. (2006). Framing leadership and belonging: An analysis of frames utilization by middle school principals and the relationship to students' and teachers' sense of belonging to the school. (Doctoral dissertation). Retrieved from OCLC FirstSearch. (AAT 3211897)

Osborn, R., \& Hunt, J. (1975). Relations between leadership, size, and subordinate satisfaction in voluntary organization. Journal of Applied Psychology, 60(6), 730-735.

O’Shea, D. (1976). Survey of preferences for alternative models. In R. F. Campbell \& T. Mazzoni (Eds.), State policy making for the public schools; A comparative analysis of policy making for the public schools in twelve states and a treatment of state governance models. Berkeley, CA: McCrutchan Publishing Company.

Penix, G. (2009). A study of Teacher Perceptions of the Relationship Between Leadership Styles of Principals in High and Low Performing West Virginia Elementary Schools. (Unpublished Doctoral Dissertation). West Virginia University, Morgantown.

Poniatowski, D. (2006). The relationship of student achievement to principals' self-reported use of the four-frame theory. (Doctoral dissertation). Retrieved from ProQuest Digital Dissertations. (AAT 3233888)

Raven, B. H. (1965). Social influence and power. In I.D. Steiner \& M. Fishbein (Eds.). Current studies in social psychology (pp. 371-382). New York: Holt, Rinehart, Winston.

Raven, B. H. (1992). A power/interaction model of interpersonal influence: French and Raven thirty years later. Journal of Social Behavior and Personality, 7, 217-244.

Raven, B. H. (1993). The bases of power: Origins and recent developments. Journal of Social Issues, 49, 227-251. 
Raven, B. H. (2008). The bases of power and the power/interaction model of interpersonal influence. Analysis of Social Issues and Public Policy, 8(1), 1-22.

Runkle, K. D. (2004). Value reflection and styles of leadership: Female California community college presidents. (Doctoral Dissertation). Retrieved from ProQuest Digital Dissertations. (AAT 3136906)

Russell, C. A. (2000). Community college academic deans: Leadership frames and stress (Doctoral dissertation). Retrieved from ProQuest Digital Dissertations. (AAT 9990484) Sanchez, K., \& Hall, G. (1987). Models for selecting chief state school officers (Policy Memo Series, No. 1). Bloomington, IN: Consortium on Educational Policy Studies.

Schwarzwald, J., Koslowsky, M., \& Brody-Shamir, S. (2006). Factors related to perceived power usage in schools. British Journal of Educational Psychology, 76, 445-462.

Shafritz, J., Ott, J, \& Jang, Y. (2005). Classics of organization theory $\left(6^{\text {th }}\right.$ ed). Belmont, CA: Thomason Wadsworth.

Shamir, B., House, R. J., \& Arthur, M. B. (1993). The motivational effects of charismatic leadership: A self-concept based theory. Organizational Science, 4(4), 577-594.

Sypawka, W. (2008). A study of division deans' in the North Carolina Community College System self perceived leadership style based on Bolman and Deal's four frame theory (Doctoral dissertation). Retrieved from ProQuest Digital Dissertations. (AAT 3303589)

Stogdill, R. (1948). Personal factors associated with leadership: A survey of the literature. Journal of Psychology, 25, 35-71.

Stogdill, R. (1974). Handbook of leadership: A survey of the literature. New York: Free Press. 
Tannenbaum, R., \& Schmidt, W. (1958). How to choose a leadership pattern. Harvard Business Review, 36, 95-101.

Toy, T. C. (2007). The self-perceived leadership style and comprehensive profile of African American women in the role of president at four-year historically black colleges and universities (HBUs) in the United States. (Doctoral dissertation). Retrieved from ProQuest Digital Dissertations. (AAT 3319306)

U.S. Census Bureau. (n.d). Census of population and housing. Retrieved April 15, 2013, http://www.census.gov/prod/www/decennial.html.

United States Census Bureau. (2010). School enrollment: CPS October 2010-Detailed Tables. Retrieved from http://www.census.gov/hhes/school/data/cps/2010/tables.html.

United States Census Bureau. (2011). Statistical Abstract of the United States: 2011. Retrieved from http://www.census.gov/prod/2011pubs/11statab/educ.pdf.

United States Census Bureau. (2012). Annual survey of public employment and payroll: Summary report: 2010. Retrieved from http://www.census.gov/prod/2012pubs/g10aspep.pdf.

United States Department of Commerce, Bureau of the Census. (1962). 1960 Census of Population, Supplementary Reports: School enrollments and educational attainment for the United States: 1960. Retrieved from http://www.census.gov/population/socdemo leducation/cp60pcs1-20/cp60pcs1-20.pdf.

United States Department of Education (2009). Fiscal Year 2010-FY 2012 President's Budget State Tables for the U.S. Department of Education. Retrieved from http://www2.ed.gov /about/overview/budget/statetables/11stbystate.pdf. 
Vroom, V., \& Yetton, P. (1973). Leadership and decision-making. Pittsburgh: University of Pittsburgh Press.

Ward, D. E. (2006). Dominant leadership frames of reference for active Indiana public school superintendents. (Doctoral dissertation). Retrieved from ProQuest Digital Dissertations. (AAT 3251420)

Weber, M. (1947). The theory of social and economic organizations. Translated by T. Parsons. New York: Free Press.

Welch, M. C. (2002). Leadership frames of female presidents of American research universities. (Doctoral dissertation). Retrieved from ProQuest Digital Dissertations. (AAT 3065731)

Winans, D. P. (1995). School board/superintendent frames of reference from school districts engaged in systemic change. (Doctoral dissertation). Retrieved from OCLC FirstSearch. (AAT 9544867)

Yukl, G. (1982, October). Managerial leadership and the effective principal. Paper presented at the meeting of the National Conference on the Principalship, Washington, DC.

Yukl, G. (2006). Leadership in organizations ( $6^{\text {th }}$ ed.). New Jersey: Pearson-Prentice Hall.

Zinth, K. \& Bush, M. (2010). Education Commission of the States, State Notes, State Comparisons/Statistics: What Governors Need to Know: Highlights of State Education Systems. Retrieved from http://www.ecs.org/clearinghouse/85/69/8569.pdf.

Zhou, L. (2010). Revenues and Expenditures for Public Elementary and Secondary Education: School Year 2007-08 (Fiscal Year 2008) (NCES 2010-326). U.S. Department of Education. Washington, DC: National Center for Education Statistics. Retrieved from http://nces.ed.gov/pubsearch/pubsinfo.asp?pubid=2010326 
From:

Sent:

To:

Subject:
Bolman, Lee G. [BolmanL@umkc.edu]

Friday, November 06, 2009 12:02 AM

Lori Wiggins

RE: Request to use Leadership Orientation (Self) Instrument

Dear Ms. Wiggins,

Based on your agreement to the points in your email message, I am happy to grant you permission to use the Leadership Orientations survey and to distribute it electronically.

Best wishes in your research.

Lee G. Bolman, Ph.D.

Professor and Marion Bloch/Missouri Chair in Leadership

Bloch School of Business and Public Administration

University of Missouri-Kansas City

5100 Rockhill Road

Kansas City, MO 64110

Tel: (816) 235-5407

From: Lori Wiggins [mailto:Iwiggins@access.k12.wv.us]

Sent: Thursday, November 05, 2009 4:57 PM

To: 'Dr. Bolman'

Subject: Request to use Leadership Orientation (Self) Instrument

Good afternoon Dr. Bolman,

I am a doctoral candidate at West Virginia University in Educational Leadership Studies. I am requesting your permission to use the Leadership Orientation (Self) survey instrument as a part of my dissertation entitled "Leadership Styles of Chief State School Officers." Additionally, I am requesting permission to distribute the survey electronically, using Zoomerang Survey Software.

Your four-frame model is the conceptual framework for my study of leadership styles. The intent of the study is to describe the leadership styles of the chief state school officers, and then see if there is a relationship between the leadership style and the model of educational governance of the state.

I accept the conditions under which you grant permission such as, providing a copy of any research report that I should produce using data from the Instrument, sharing a copy of the data file should it be requested, and making the results of my research available to you upon request. It is my hope that you will grant permission to continue this research.

Thank you for considering this request. If I may provide additional information, please feel free to contact me. I may be reached by telephone at 800.982 .2378 or by email at lwiggins@access.k12.wv.us.

Sincerely,

Lori Wiggins 


\section{- West VurginiaUniversity. \\ Otfice of Research Compliance}

\section{Expedited-IRB Protocol-Exemption}

To: $\quad$ Chapman, Paul

From: $\quad$ WVU Office of Research Compliance

Date: $\quad$ Saturday, February 13, 2010

Subject: Exemption Acknowledgement

Tracking \#: $\mathrm{H}-22237$

Title: $\quad$ The Self Perceived Leadership Styles and State Models of Educational Governance of Chief State School Officers in the United States

The above-referenced study was reviewed by the West Virginia University Institutional Review Board (IRB) and was granted exemption in accordance with 45 CFR 46.101(2).

This protocol was reviewed using the following:

This research study was granted an exemption in accordance withResearch that involves educational tests, survey procedures, interview procedures, or observation of public behavior [45 CFR 46.101(2)].210r was used for this approval.Please note that the cover letter should say acknowledged by the IRB, not approved. You may wish to change that and submit as an amendment.

The following documents have been acknowledged for use in this study and are available in the BRAAN system:

Attachments Zoom Survey.pdf Survey Instrument Miscellaneous Attachments Attachments Chief Letter.pdf Initial letter to chief state school officers Follow-Up Survey Email.pdf Follow-up email script Follow-Up Survey Telephone Script.pdf Follow-up telephone script

Thank you.
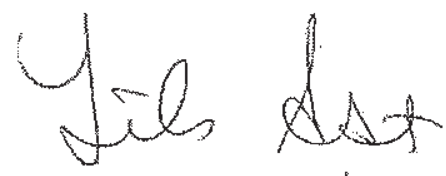

Board Designee: Ast, Lilo

Letter Sent By: Ast, Lilo, 2/13/2010 3:12 PM 
Once you begin your human subject research, the following regulations apply:

1. Any modifications to the study protocol must be reviewed and acknowledged by the IRB prior to implementation.

2. You may not use a modified form until it has been acknowledged by the IRB. 


\section{Appendix C}

\section{Dear Chief State School Officer:}

I am writing to you to request your participation in a research survey of all the chief state school officers of the United States. The project is being conducted by Lori Wiggins, a doctoral student in the Educational Leadership Studies Department of WVU. The position of chief state school office is pivotal, especially in the today's educational climate for the current and future well-being of all the public school aged children in the United States of America. Being the leader of a state education agency, you are aware of the skills, talents, and aptitudes that are required to lead that organization and also to answer to and influence the many constituencies and educational stakeholders.

Unfortunately, there is a paucity of research on the leadership styles and practices of chief state school officers. I am conducting this survey to learn more about the leadership styles of the chief state school officers of the United States. Specifically, I wish to identity the leadership styles of the chief state school officers and see if there is a relationship between style, select demographic variables, and the model of state educational governance. The survey will serve as the research instrument to supply the needed information to complete my dissertation and ultimately my doctoral studies at West Virginia University.

As a chief state school officer, your participation is being requested with this dissertation project. The survey instrument used is from the wok of Lee Bolman and Terrence Deal and their Four-Frame Leadership Orientation Model. Permission has been obtained from the authors to use their survey instrument in this research project.

Below you will find a link to the Leadership Orientation questionnaire. In order to obtain the results that will be representative of the chief state school officers, I would greatly appreciate it if you would complete the on-line, web-based survey questionnaire. Your involvement in this project will be kept as confidential as legally possible. The demographic information that will be collected is publicly available. The research data will not be identified with personal information. All research data will be reported in the aggregate. Your participation is completely voluntary. The questionnaire should take no more than seven to twelve minutes to complete. You may skip any question that you do not wish to answer and you may discontinue at any time. The Institutional Review Board at WVU has reviewed this project and the approval is on file.

Once I receive the responses from the survey questionnaires, I will also be conducting interviews of chief state school officers to gain a more detailed understanding of their leadership styles. If you are interested in participating in a follow-up interview regarding your experience as a chief state school officer, please indicate your willingness in the survey.

It is my sincere wish that you will participate in this research project, as it could be beneficial in providing data for further investigation into the leadership practices of chief state school officers, potential use for the development of leadership programs for chief state school officers, and for use by institutions of higher education in planning and developing leadership studies course work. 
Upon completion of this research, the findings will be published in a doctoral dissertation. In addition, if you would like a summary of the results of this study, please indicate this on the survey. Thank you very much for your time. Should you have any questions about this letter or the research project, please contact me at the following e-mail address, lwiggins@access.k12.wv.us.

Guidelines for participating in the survey:

1) Access the online Chief State School Officer questionnaire at the following web address: http://www.zoomerang.com/Survey/?p=WEB228CMU.

Thank you for your time and assistance with this project. You

Sincerely,

Loriwiggins 

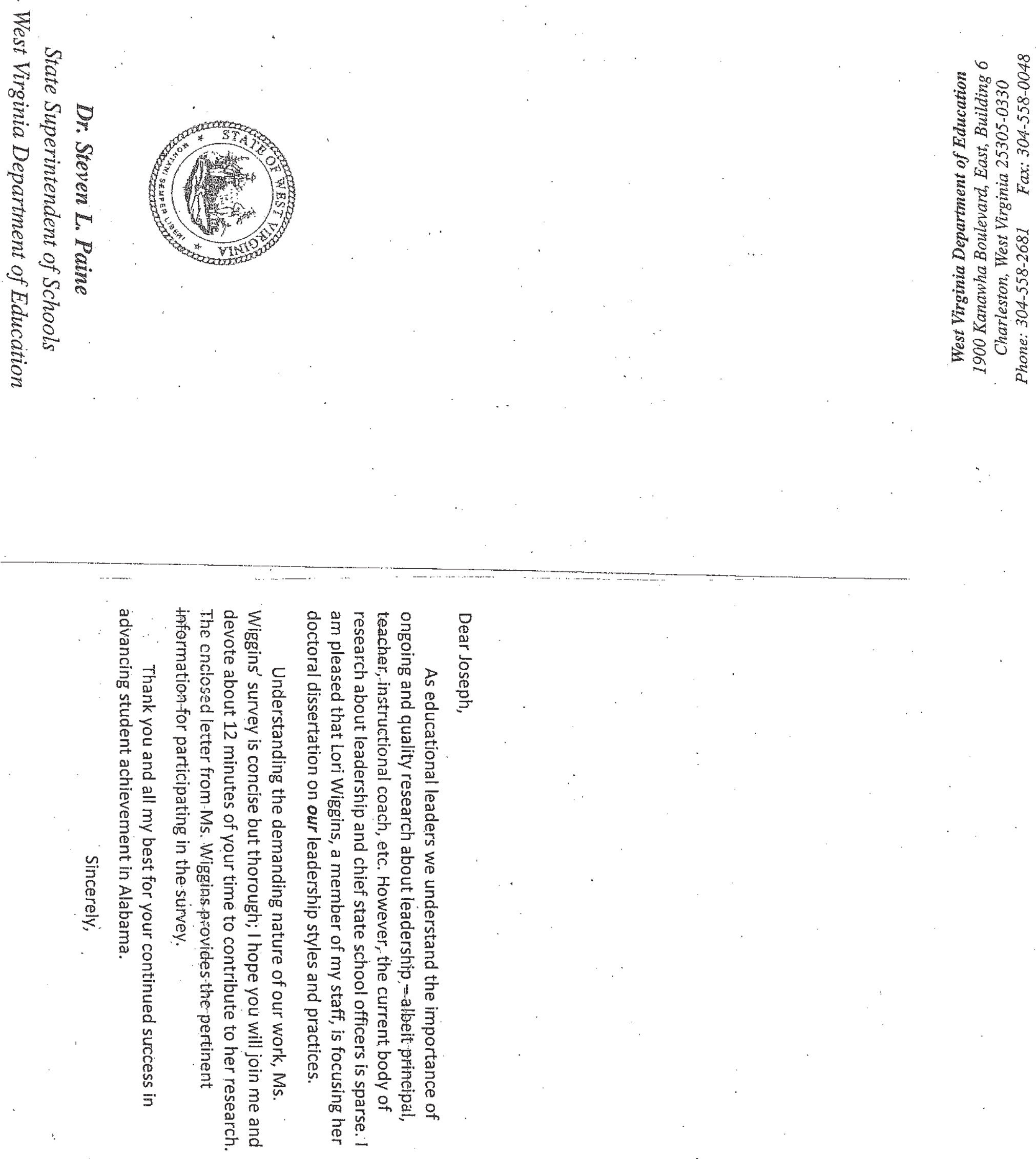
Appendix E

\section{Follow-up Email Script - Requesting Survey Participation}

Dear Chief State School Officer:

On (date)___ I mailed you a letter inviting you to participate in a research survey of all the chief state school officers of the United States. The project is being conducted by me, Lori Wiggins, a doctoral student in the Educational Leadership Studies Department of WVU. As of today __(date) _ I I have not received your survey response.

Results from this study will provide valuable data for an understudied and influential group of educators. The data could be important for further investigation into the leadership practices of chief state school officers, potentially used for the development of leadership programs for chief state school officers, and used by institutions of higher education in planning and developing leadership studies course work.

It is my sincere wish that you will participate in this research project. The survey should take no longer than seven (7) to twelve (12) minutes to complete.

If you would like another copy of the letter prior to completing the survey, I would be happy to FAX or e-mail it to you. Please indicate your preference.

If no additional materials are needed, the survey may be accessed at the following Web site: http://www.zoomerang.com/Survey/

Thank you again for your time and assistance with this research project.

Sincerely, LoríWiggins 
Appendix F

Dear

I have previously invited you to participate in a research survey of all the chief state school officers of the United States. The project is being conducted by me, Lori Wiggins, a doctoral student in the Educational Leadership Studies Department at West Virginia University (WVU). As of today, March 8, 2010, I have not received your survey response.

As a state education agency employee, I am aware of the tremendous time demands on chief state school officers. I have firsthand knowledge of Dr. Paine's schedule. However, the results from this study will provide valuable data about an understudied and influential group of educators.

It is my sincere wish that you will participate in this research project. The survey should take no longer than seven (7) to twelve (12) minutes to complete. For your convenience, I have attached a copy of the electronic survey. In addition to its validity and reliability, one reason that the survey for this research project was selected was for its brevity.

The survey may be accessed at the following Web site:

http://www.zoomerang.com/Survey/?p=WEB22A6UT2Z4UQ

If you would like another copy of the letter prior to completing the survey, I would be happy to FAX or e-mail it to you. If you would prefer to complete the PDF version of the survey, you may return it to me by fax or US postal mail.

Fax number: 304-558-6527

Mailing address:

Lori Wiggins

1613 Franklin Avenue, Apt 1

Charleston, WV 25311

Thank you again for your time and assistance with this research project. May the work you do to increase student achievement for the students of be acknowledged, appreciated, and have significant impact.

Sincerely, LoríWiggins 


\section{Appendix G \\ LEADERSHIP ORIENTATIONS (SELF)}

(1990, Lee G. Bolman and Terrence E. Deal, all rights reserved

This questionnaire asks you to describe the person that you are rating in terms of leadership and management style.

\section{Leader Behaviors}

You are asked to indicate how often each item is true of the person that you are rating. Please use the following scale in answering each item.

\section{1-Never 2-Occasionally 3-Sometimes 4-Often 5-Always}

So, you would answer ' 1 ' for an item that is never true of the person you are describing, ' 2 ' for one that is occasionally true, ' 3 ' for one that is sometimes true, and so on.

Be discriminating! The results will be more helpful to the ratee if you think about each item and distinguish the things that the ratee really does all the time from the things that $\mathrm{s} / \mathrm{h}$ does seldom or never.

1. Thinks very clearly and logically.

2. Shows high levels of support and concern for others.

3. Shows exceptional ability to mobilize people and resources to get things done.

4. Inspires others to do their best.

5._ Strongly emphasizes careful planning and clear time lines.

6. _ Builds trust through open and collaborative relationships.

7.___ Is a very skillful and shrewd negotiator.

8._Is highly charismatic.

9._ Approaches problems through logical analysis and careful thinking.

10 __ Shows high sensitivity and concern for others' needs and feelings.

11. Is unusually persuasive and influential.

12. Is Is an inspiration to others.

13. Develops and implements clear, logical policies and procedures.

14. Fosters high levels of participation and involvement in decisions.

15. ___ Anticipates and deals adroitly with organizational conflict.

16. Is highly imaginative and creative.

17. Approaches problems with facts and logic.

18. Is consistently helpful and responsive to others.

19. Is I v very effective in getting support from people with influence and power.

20. Communicates a strong and challenging vision and sense of mission.

21. Sets specific, measurable goals and holds people accountable for results.

22. Listens well and is unusually receptive to other people's ideas and input.

23. Is politically very sensitive and skillful.

24. Sees beyond current realities to create exciting new opportunities.

$25 . \quad H a s$ extraordinary attention to detail.

26. Gives personal recognition for work well done.

27. Develops alliances to build a strong base of support.

28. Generates loyalty and enthusiasm.

29. Strongly believes in clear structure and a chain of command.

30. Is a highly participative manager.

31. Succeeds in the face of conflict and opposition.

32. Serves as an influential model of organizational aspirations and values. 


\section{Chief State School Officers Questionnaire}

The survey questionnaire asks you to describe characteristics of your leadership style. It is a 41 item questionnaire. There are 7 demographic variable questions. There are 32 Likert rating survey items, and two yes/no questions. The survey should take about seven to welve minutes to complete.

The survey is confidential. Participation in the survey is voluntary. You may skip any questions you do not wish to answer and you may discontinue at any time.

Your assistance is enthusiastically appreciated!

\section{SELECT DEMOGRAPHIC VARIABLES}

\begin{tabular}{|c|c|c|c|c|}
\hline \multirow[t]{3}{*}{1} & \multicolumn{4}{|l|}{ Age } \\
\hline & $\begin{array}{c}\text { Younger than } 40 \text { years } \\
\text { of age }\end{array}$ & 40 to 49 & 50 to 59 & 80 years or older \\
\hline & 4 & 30 & 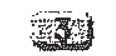 & 1 \\
\hline
\end{tabular}

2. Gender

\begin{tabular}{|c|c|}
\hline Mate & Fomale \\
\hline (1) & ig \\
\hline
\end{tabular}

3 Ethnicity

9 White, Non-Hispanic

Black or African American

15ispanic or Latino

Asian

(9) American Indian or Alaska Native

(3) Native Hawaiian or Pacific Islander

Other, please specify 
4 Highest Degree Earned

Bachelor's Degree

aster's Degree

90 Doctoral Degree (Ed.D or Ph.D)

(3) Other Terminal Degree, please specify

5 Years of experience as chief state school officer

6 Years of adminstrative experience (excluding current position)

7 Total years of experience in an educational setting (including current position)

\title{
Chief State School Officers Questionnaire
}

\section{LEADERSHIP ORIENTATIONS (SELF)}

\author{
(C) 1990, Lee G. Bolman and Terrence $\mathrm{E}_{\text {. Deal, all rights }}$ \\ reserved
}

This questionnaire asks you to describe the person that you are rating in terms of leadership and management style.

\section{Leader Hohaviors}

You are asked to indicate how ofien each item is true of the person that you me rating. 
Please use the following scale in answering each item.

1-Never 2-Occasionally 3-Sometimes. 4-Often 5-Always

So, you would answer ' 1 ' for an item that is never true of the person you are describing, ' 2 ' for one that is occasionally true, ' 3 ' for one that is sometimes true, and so on.

Be discriminating! The results will be more helpful to the ratee if you think about each item and distinguish the things that the ratee really does all the time from the things that s/he does seldom or never.

8 SURVEY ITEM \#1 - Thinks very clearly and logically.

\begin{tabular}{|c|c|c|c|c|}
\hline Never & Occasionally & Sometimes & Offen & Always \\
\hline ij & 2 & 3 & 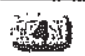 & 5 \\
\hline
\end{tabular}

9 SURVEY ITEM \#2 - Shows exceptional ability to mobilize people and resources to get things done.

\begin{tabular}{|c|c|c|c|c|}
\hline Never & Occastionally & Sonetimes & Ofen & Always \\
\hline ix & (1) & 3 & 4 & 5 \\
\hline
\end{tabular}

10 SURVEY ITEM \#3 - Shows exceptional ability to mobilize people and resources to get things done.

\begin{tabular}{|c|c|c|c|c|}
\hline Never & Occasionally & Sometimes & Oten & Always \\
\hline$g$ & $2 \mathrm{~s}$ & (3) & 4 & 159 \\
\hline
\end{tabular}

11 SURVEY ITEM \# 4 - Inspires others to do thier best.

\begin{tabular}{|c|c|c|c|c|}
\hline Never & Occasionaly & Sometim & Onen & Always \\
\hline (1) & iag & 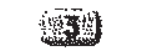 & 20 & 35 \\
\hline
\end{tabular}

12 SURVEY ITEM 5 - Stongly emphasizes careful planning and clear time lines.

\begin{tabular}{|c|c|c|c|c|}
\hline Never & Occasionally & Somettmes & Often & Atways \\
\hline 涪 & 2 & 5 & 4 & 5 \\
\hline
\end{tabular}


13 SURVEY ITEM \#6 - Builds trust through open and collaborative relationships.

\begin{tabular}{|c|c|c|c|c|}
\hline Never & Occasionally & Sometimes & Often & Always \\
\hline 19 & 2 & 3 & 19u & 5 \\
\hline
\end{tabular}

14 SURVEY ITEM \#7 - Is a very skillful and shrewd negotiator.

\begin{tabular}{|c|c|c|c|c|}
\hline Never & Occasionally & Sometimes & Often & Always \\
\hline 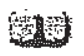 & 3 & 3 & 4 & 15 \\
\hline
\end{tabular}

15 SURVEY ITEM\#8 - Is highly charismatic.

\begin{tabular}{|c|c|c|c|c|}
\hline Naver & Occasionall & Sometimes & Othen & Always \\
\hline a & 政拄 & (5) & 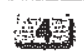 & 55 \\
\hline
\end{tabular}

16 SURVEY ITEM - Approaches problems through logical analysis and careful thinking.

\begin{tabular}{|c|c|c|c|c|}
\hline Naver & Occasionally & Sometimes & Olten & Aways \\
\hline ay & 2 & 3 & 4 & is \\
\hline
\end{tabular}

17 SURVEY ITEM \#10 - Shows high sensitivity and concem for others' needs and feelings.

\begin{tabular}{|c|c|c|c|c|}
\hline Never & Oxxastonally & Sometimes & Often & Aways \\
\hline 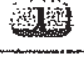 & (203) & 3 & Us & 磨得 \\
\hline
\end{tabular}

18 SURVEY ITEM *11 - Is unusually persuasive and influential.

\begin{tabular}{|c|c|c|c|c|}
\hline Never & Occasionally & Sometimos & Often & Always \\
\hline risio & rev & 20 & 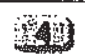 & 5 \\
\hline
\end{tabular}


19 SURVEY ITEM 12 - Is an inspiration to others.

\begin{tabular}{|c|c|c|c|c|}
\hline Never & Occaslonally & Sometines & Often & Never \\
\hline 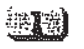 & 80 & 㱟 & a & 5 \\
\hline
\end{tabular}

20 SURVEY ITEM \# 13 - Develops and implements clear, logical policies and procedures.

\begin{tabular}{|c|c|c|c|c|}
\hline Never & Occasionally & Sometimes & Ofien & Awways \\
\hline 13 & 22 & i⿺廴 & 40 & 5 \\
\hline
\end{tabular}

21 SURVEY ITEM \# 14 - Fosters high levels of participation and involvement in decisions.

\begin{tabular}{|c|c|c|c|c|}
\hline Newer & Occasionally & Sometintes & Often & Atways \\
\hline 3 & 23 & 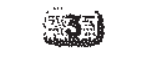 & 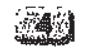 & 5 \\
\hline
\end{tabular}

22 SURVEY ITEM 15 - Anticipates and deals adroitly with organizational conflict.

\begin{tabular}{|c|c|c|c|c|}
\hline Never & Occasionally & Somptimes & Ollen & Aways \\
\hline 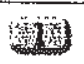 & 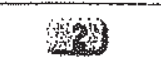 & 3i & ats & 5 \\
\hline
\end{tabular}

23 SURVEY ITEM \#16 - Is imaginative and creative.

\begin{tabular}{|c|c|c|c|c|}
\hline Never & Occastonally & Sometimes & Ofiten & Ahways \\
\hline It) & : & 3 & sis & 55: \\
\hline
\end{tabular}

24 SURVEY ITEM \#17 - Approaches problems with facts and logic.

\begin{tabular}{|c|c|c|c|c|}
\hline Never & Occasionaly & Sometimes & Often & Always \\
\hline 1 & 42 & 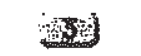 & (1) & 5 \\
\hline
\end{tabular}

25 SURVEY ITEM \#18 - Is consistently helpful and responsive to others. 


\begin{tabular}{|c|c|c|c|c|}
\hline Never & Oxcasionally & Sometimes & Often & Atways \\
\hline a & 2 & 3 & 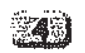 & 5 \\
\hline
\end{tabular}

26 SURVEY ITEM \#19 - Is very effective in getting support form people with influence and power.

\begin{tabular}{|c|c|c|c|c|}
\hline Never & Occasionally & Sometimes & Often & Always \\
\hline 10 & 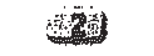 & 3 & 4 & 5 \\
\hline
\end{tabular}

27 SURVEY ITEM \#20 - Communicates a strong and challenging vision and sense of mission.

\begin{tabular}{|c|c|c|c|c|}
\hline Never & Occasionally & Sometimes & Often & Always \\
\hline 满请 & 12 & 18 & 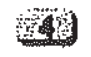 & S \\
\hline
\end{tabular}

28 SURVEY ITEM \#21 - Sets specific, measurable goals and holds people accountable for results.

\begin{tabular}{|c|c|c|c|c|}
\hline Never & Occasionally & Sometimes & Otten & Always \\
\hline in & 3 & 8 & 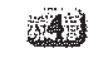 & 5 \\
\hline
\end{tabular}

29 SURVEY ITEM \#22 - Listens well and is unusually receptive to other people's ideas and input.

\begin{tabular}{|c|c|c|c|c|}
\hline Never & Occasionally & Sometimes & Often & Always \\
\hline 致 & 10 & 3 & 5 & 5 \\
\hline
\end{tabular}

30 SURVEY ITEM \#23 - Is politically very sensitive and skilliul.

\begin{tabular}{|c|c|c|c|c|}
\hline Never & Occasionally & Somotimes & Often & Always \\
\hline 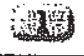 & in & w & 19 & 政 \\
\hline
\end{tabular}

31 SURVEY ITEM \#24 - Sees beyond current realities to create exciting new opportunities. 


\begin{tabular}{|c|c|c|c|c|}
\hline Never & Occasionally & Sometimes & Often & Always \\
\hline$\sqrt{1203}$ & a & 3 & 4 & 5 \\
\hline
\end{tabular}

32 SURVEY ITEM \#25 - Has extraordinary attention to detail.

\begin{tabular}{|c|c|c|c|c|}
\hline Naver & Occasionally & Sometimes & Oflen & Always \\
\hline 㻗 & (3) & 3 & 4 & 1 \\
\hline
\end{tabular}

33 SURVEY ITEM \#26 - Gives personal recognition for work well done.

\begin{tabular}{|c|c|c|c|c|}
\hline Never & Occastonally & Sometimes & Otlen & Always \\
\hline 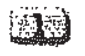 & w & 3 & (1) & 5 \\
\hline
\end{tabular}

34 SURVEY ITEM \#27 - Develops alliances to build a strong base of support.

\begin{tabular}{|c|c|c|c|c|}
\hline Never & Occasionally & Sometimes & Often & Always \\
\hline Aq & 2 & 33 & Afo & 35 \\
\hline
\end{tabular}

35 SURVEY ITEM \#28 - Generates loyalty and enthusiasm.

\begin{tabular}{|c|c|c|c|c|}
\hline Never & Occasionally & Sometimes & Often & Always \\
\hline in & 189 & 9 & 2 & (1) \\
\hline
\end{tabular}

36 SURVEY ITEM \#29 - Strongly believes in clear structure and a chain of command.

\begin{tabular}{|c|c|c|c|c|}
\hline Never & Occasionally & Sometimes & Oten & Always \\
\hline 部 & 2 & 5 & 19 & 5 \\
\hline
\end{tabular}

37 SURVEY ITEM \#30 - Is a highly participative manager.

\begin{tabular}{|c|c|c|c|c|}
\hline Nover & Occasionally & Sometinnes & Oflen & Always \\
\hline 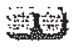 & 20 & 13is & 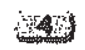 & 3 \\
\hline
\end{tabular}




\section{Chief State School Officers Questionnaire}

38 SURVEY ITEM \# 31 - Succeeds in the face of conflict and opposition.

\begin{tabular}{|c|c|c|c|c|}
\hline Nover & Occasionally & Sometlmes & OAten & Always \\
\hline 微尌 & 23 & 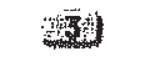 & wiy & 5 \\
\hline
\end{tabular}

39 SURVEY ITEM \#32 - Serves as an influential model of organizational aspiraions and values.

\begin{tabular}{|c|c|c|c|c|}
\hline Nover & Occasionally & Somotimes & Onten & Always \\
\hline 漼硯 & 2 & 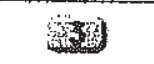 & Ha & 45 \\
\hline
\end{tabular}

40 I would be willing to participate in a follow-up interview regarding my experience as a chief state school officer.

\begin{tabular}{cc} 
Yas & No \\
\hline y & Nog \\
\hline
\end{tabular}

41 Upon completion of this research, I would like a summary of the results of the study.

\begin{tabular}{|c|c|}
\hline Yes & No \\
\hline 铋 & W \\
\hline
\end{tabular}

\section{Chief State School Officers Questionmaire}


